\title{
Rosa Alcoy
}

\section{LA PASSIÓ SEGONS TINTORETTO. DEL JUDICI AL DAVALLAMENT}

Il più terribile cervello che abbia avuto mai la pittura.

GIORGIO VASARI

\section{Consideració preliminar}

Abans d'entrar en matèria m'agradaria explicar el meu interès per Tintoretto com a medievalista i historiadora de l'art. ${ }^{1}$ Potser serviria dir que les meves primeríssimes classes el van tenir com a protagonista, juntament amb Paolo Veronese. ${ }^{2}$ Abocada per exigències de la docència del moment a parlar d'egipcis, del Veronès i de Tintoretto en un conglomerat rar però engrescador, em va atraure en particular l'obra del darrer. En tenia alguna noció i m'interessava el seu tractament del color i de les formes, que el portaria a adobar, amb un esperit certament original, uns continguts coneguts i que, en alguna mesura i per raó d'aquest mateix tractament extraordinari, es removien per descobrir-nos vessants insospitats d'una matèria religiosa o mitològica prou extensa. No negaré que en I'elecció també pesa el meu rebuig d'unes especialitats definides per cronologies i que, massa tancades en elles mateixes, descriuen una dictadura absoluta llargament imposada en els nostres camps d'estudis. Podria afirmar que vaig deixar de creure, ja fa molt, que l'estudi de l'art hagi de tenir fronteres temporals que no cal traspassar. La veritat és que no hi he cregut mai, encara que poc o molt hagi respectat el perfil de medievalista, impel.lida per la seqüència dels treballs en curs 0 altres factors afegits $i$ un marc d'estudis força específic que, vist aïlladament i quan apareix blindat artificiosament, repercuteix de manera negativa en els resultats i, en definitiva, fa més mal que bé.

El fet és que les meves primeres recerques no es van inscriure en el camp de l'art medieval. ${ }^{3}$ La meva intenció era dedicar els estudis a l'art contemporani, fonamentalment a l'art dels segles XIX i XX, al qual mai no he donat l'esquena del tot $i$, així, per bé que la tradició artística de la densa Edat Mitjana ha estat I'objectiu principal de la meva recerca, també és cert que $\mathrm{m}^{\prime}$ he interessat de forma progressiva per qüestions que avancen
MATÈRIA, núm. 16-17, 2020, ISSN 1579-2641, p. 75-148

Recepció: 21-1-2020

Acceptació: 18-3-2020

1 Aquest estudi es pot situar entre les recerques $\mathrm{col} \cdot \cdot$ laterals 0 complementàries del projecte $d^{\prime} R+D:$ HAR2017-85910-P: «Justicia y Juicio: representaciones artísticas en la Cataluña medieval y moderna» del Grup EMAC de la Universitat de Barcelona, amb finançament del Ministeri de Ciència, Innovació i Universitats, Agència Estatal d'Investigació. Fondo Europeo de Desarrollo Regional, Unió Europea.

2 Impartides en el meu breu pas per la Universitat Autònoma de Barcelona, en un ja remot curs 1983-1984 i per encàrrec del professor Bonaventura Bassegoda, a qui he d'agrair aquest bateig "modernista». Per més que les classes inicials potser és millor no recordar-les gaire.

${ }^{3}$ L'art funerari català de I'entorn del 1900 va ser el tema 
de la meva tesi de llicenciatura, presentada el setembre del 1983 a la Universitat de BarceIona i publicada temps després: Rosa Alcoy, El cementiri de Lloret de Mar. Indagacions sobre un conjunt modernista, amb pròleg de J. Rogelio Buendía, Santa Coloma de Farners, Ajuntament de Lloret de Mar, 1990.

${ }^{4}$ Per enfilar-se des del món medieval a aquest moment de la història de l'art, ha estat ideal treballar sobre Bosch ja al monogràfic de la revista Matèria. Revista internacional d'Art: Bosch al país de l'art, núm. 10-11, any 2016, i a través d'un parell d'estudis monogràfics que s'han reunit en un únic $\| l i-$ bre, l'original del qual ja s'ha lliurat a l'editorial.

${ }^{5}$ La teoria no és innòcua i cada vegada que se'n fa propaganda en una direcció lineal, i sense matisos, hem de sospitar de les intencions reals que amaga i que caldria fer aflorar. Al capdavall, de confort en una torre no n'hi ha gaire, i menys, és clar, si l'hem convertit en una fortalesa o presó, a la manera potser de la famosa Bastilla del cardenal Richelieu.

6 Tintoretto també ha estat tema en I'assignatura Art i Encanteri. Teoria de la Representació Medieval i Postmedieval, que he impartit al llarg de vuit cursos continuadament. Aquesta part de la meva docència és la base d'un llibre en premsa que, amb el mateix títol que el curs, al·ludeix al pintor venecià en el capítol «Escenaris i atmosferes a partir de Tintoretto». vers la teoria i les transformacions que amb pas inexorable defineixen l'art de I'època moderna. ${ }^{4}$ Confrontar aquestes realitats amb les crescudes del segle XIX i de l'art més recent és molt interessant. No deixa de ser fàcil concloure que cadascú crea les seves pròpies torres de marfil, o se les fa a mida, encara que tinc clar que això que dic no és cert del tot. És just reconèixer que certa pressió ambiental té incidència en l'abast dels nostres estudis. Pel que $\mathrm{m}^{\prime}$ afecta $\mathrm{i}$ al marge d'una nítida percepció en què sobreviu el parany, I'entenc cada cop més mitigada, ja sigui perquè em miro les coses amb més distància o perquè algunes de les vestals i els gurus que havien definit els límits més durs ja no hi són, no són on eren o han canviat d'idea. En contrapartida, també és cert que, des de molt aviat, vaig gaudir del contacte amb persones que, dins de la professió, apuntaven en una direcció oposada a les diacronies sectàries. Me les vaig trobar dins i fora de I'anomenada acadèmia, terme, aquest darrer, amb un regust inevitablement antic que aparia pàtines enrarides amb prejudicis diversos, per més que pugui servir per entendre'ns. Ser valedor d'una visió més transversal i integradora dels estudis sobre etapes distintes no equival a defensar, que quedi ben clar, que s'hagi de saber de tot per un igual o que els interessos no es puguin bifurcar en sentits heterogenis o delimitar de manera parcial. Si fem cas de les biografies d'insignes estudioses i estudiosos de l'art, observarem que els horitzons acostumen a moure's endavant i endarrere, amb prou desimboltura en alguns casos. No es tracta d'entrar ara a fons ni en qüestions historiogràfiques profundes ni en les seves causes internes, conscient que els motors, per més amagats que es trobin, acostumen a fer soroll. Procurar sortir de la torre, però, ni que sigui de tant en tant, em sembla més que saludable.

En definitiva, independentment de si el panorama global és més afecte o més advers a una tendència o a l'altra, sortir de la conjecturada torre, no imaginada ben bé com a àrea de confort, ${ }^{5}$ fa que corri I'aire i permet deturar-se en aspectes que enriqueixen la interpretació que, laminada a partir de les herències $d^{\prime} u n$ art anterior, va interessar als millors artistes de cada nou present. I és una dependència, o addicció voluntària, que no puc defugir en nom de cap visió creacionista, antihistòrica 0 asimptomàtica. ${ }^{6}$

Aquest nou volum de Matèria, que es dedica a la memòria del professor Joaquim Garriga, m'ha semblat el Iloc ideal on atrevir-me a embastar, ni que sigui de manera ràpida, un seguit de consideracions i apunts sobre les escenes de la Passió que va explorar el gran Tintoretto, sobretot a la seva Venècia natal, per introduir-hi expressions, formes i continguts d'indubtable interès que ajuden a definir l'art del Cinquecento, la seva època, i a donar base als temps que seguiran, però també poden ajudar a qualificar, i reveure, el que $\mathrm{s}^{\prime}$ havia fet abans. ${ }^{7}$ Si en I'intent no puc dir tot 
el que caldria dir o desconec res que algú podria esperar que sabés, agrairé molt certa comprensió. De vegades la historiografia és tan avara com I'espai disponible en un article, igual que pot ser extensa, inabastable i ramosa, enfrontada al temps curt que hi podem dedicar.

Només afegiré, per tancar aquestes línies liminars, que el grup de recerca EMAC, al qual pertanyo, ja fa temps que ha començat a predicar amb l'exemple i, en conseqüència, tal com es pot advertir en els darrers projectes, ha fet un gir per tal d'enllaçar l'art de l'època medieval amb el de l'època moderna i contribuir a reestructurar —o més ben dit, a aprimar- unes fronteres que són massa carregoses i engreixades tan forçadament, encara avui, que generen incomunicacions absurdes, camp abonat per estendre uns prejudicis que haurem d'anar salvant fins a aconseguir un enfocament de l'art més permeable i equilibrat, dins del que sigui possible i desitjable, sense ometre, però, les dinàmiques i realitats històriques específiques de cada moment, no cal dir-ho. Més que predicar sobre la pluralitat disciplinària desbocada, o desbordant, i sovint inexplicada, defenso una visió transversal i oberta per a l'estudi de l'art, que s'hauria de manifestar exigent i multidisciplinari per se, en els marges de l'àrea de coneixement i amb una dimensió històrica que no val a negar. ${ }^{8}$

\section{El microcosmos venecià}

Més enllà de les rivalitats i les anècdotes que es vinculen al seu periple, de les nombroses històries que envolten la vida del pintor nascut a Venècia el 1518 o $15199^{9}$ més enllà de la seva vida personal i la professional que I'assenyala com algú de personalitat forta dins de la cultura, l'art i I'humanisme del seu temps, ${ }^{10}$ l'interès essencial de Tintoretto rau, al meu entendre, en el transvasament d'un caràcter impactant a la configuració d'una individualitat pictòrica que arriba associada a un llenguatge que, Iluny de voler ser arbitrari, pretén sobresortir per uns valors intrínsecs, al mateix temps que dialoga amb l'art del passat i aprecia la intel-ligència de l'espectador. Si de tant en tant el descol-loca, és per obligar-lo a retornar als temes mantenint-lo en tensió. Per aquest camí vol aconseguir l'atenció, la consideració i la reflexió del qui mira sobre allò que ell, com a pintor, li explica en un format visible, un format diferent, que no s'agenolla davant de cap discurs parlotejat ja sigui oralment o per escrit.

Jacopo tingué diversos fills, entre ells, Marietta (1554), Domenico (1560) i Marco (1561), pintors com ell. Cal tenir present que pertanyia a una família extensa, en part originària de Brescia o vinculada a la localitat. En tot cas, amb una àmplia base fornida pels de casa, Tintoretto va
7 L'article es fonamenta en la meva intervenció als Juliols de la UB del 2018, dins d'un curs específic coordinat per la professora Cristina Fontcuberta. Mantinc el títol d'una aportació que es va enriquir, el mateix any, amb la visita a Venècia i a les exposicions commemoratives del centenari del pintor.

8 Sobre les recerques del grup EMAC en aquesta direcció, vegeu els llibres dels simposis, Art fugitiu. Estudis d'art medieval desplaçati Artmedieval en joc, seguits de Judici i justícia a l'art sacre i profà medieval i modern, publicat el 2020.

9 Sovint es donen per bones les següents dates de naixement i mort: Venècia, 29 de setembre de 1518, i Venècia, maig de 1594. El tema es pot enriquiren la bibliografia sobre el pintor i confrontar amb les recerques recents de Stefania MASON, «Tintoretto Veneziano», Robert ECHOLS i Frederick ILCHMAN (eds.), Tintoretto 1519 1594 (catàleg d'exposició, Palau Ducal de Venècia, 2018), Venècia, Marsilio, 2018, p. 38-61, esp. p. 39.

10 Per al marc artístic immediat: Frederick ILCHMANN, David Rosant, Linda Borean, Patricia Brown i John GARTON, Titian, Tintoretto, Veronese: Rivals in Renaissance Venice, Boston, MFA Publications, 2009. Vegeu el text de Mason per al vincle, no sempre pacífic del tot, amb els humanistes i literats del seu entorn: S. MASON, «Tintoretto Veneziano», p. 44-47. 
11 S'arriben a considerar vint-i-dos germans, segons les informacions d'una Genealogia, segurament qüestionable a partir del que argumenta Stefania Mason en aquest punt 0 $d^{\prime}$ altres. Fossin els que fossin, serien fills de Battista, el tintorer, que donà nom professional al seu fill Jacopo, aprofitant el vincle evident dels tints amb la pintura.

12 Sobre un tema proper als que tractarem: Lionello PUPPI, "Andrea Schiavone nella bottega di Tiziano. In margine ad un inedito "Ecce Homo"», Cuadernos de Arte de la Universidad de Granada, núm. 40, 2009, p. 43-52.

13 Recordem que, conegut tradicionalment com a Jacopo Robusti, es va proposar el cognom Comin a partir d'una Genealogia que no sembla cent per cent fiable a Stefania MAsON, «Tintoretto Veneziano», p. 4041. L'autora és partidària de mantenir el cognom Robusti davant de les propostes de Falomir i no considera plausible una ascendència noble del clan. Vegeu, en tot cas, el catàleg d'una celebrada mostra: Miguel FALOMIR (ed.), Tintoretto, Madrid, Museo Nacional del Prado, 2007.

14 P. Cottrell, «Bonifacio Veronese and the young Tintoretto», Inferno, vol. Iv, 1997, p. 17-36, autor de diferents treballs sobre els Iligams de Bonifacio amb Tintoretto, entre els quals hi ha "Corporate colors: Bonifacio and Tintoretto at the Palazzo dei Camerlenghi in Venice», Art Bulletin, vol. 82, núm. 4, 2000, p. 658-678. Ve- regentar un obrador que podia i volia fer-se càrrec de grans obres. ${ }^{11}$ Tanmateix, no va diluir en les collaboracions ni el seu cos ni el seu esperit de pintor amb fonda petjada individual. En un altre ordre de temes, també sembla ben segur que va saber treure partit de les obres d'aquells artistes que I'envoltaven a la Venècia del segle XVI i que sovint gaudiren de fama molt més enllà de la ciutat. No obvià tampoc aquelles aportacions d'artistes de geni que, forans al Vèneto, podien eixamplar els seus registres amb novetats de les quals gaudiria i que injectaria amb plaer al seu propi discurs. Encara que no es pugui ser excel-lent sempre i en tot, va cultivar I'excel-lència pictòrica amb gran capacitat per digerir els encerts d'altres artistes i per apropiar-se'ls, això sí, amb coherència, de tal manera que molt difícilment el podrem considerar a remolc de res. Això no obstant, sabem que la crítica parla sovint $d^{\prime}$ un període veronesiano o veronesista en la carrera de Tintoretto. Una temptació per l'art del magnífic i preciosista Paolo Veronès (1528-1588) que, en particular i per alguns temes específics, em recorda bastant la relació que s'establí molt abans, en el pas del Duecento a la primeria trescentista, entre Cimabue i Duccio. En aquest cas, no sembla pas problemàtic imaginar qui seria Cimabue i qui, Duccio. Si apuntem paral·lelament al tractament cromàtic i a l'amabilitat figurativa, el florentí, mestre de Giotto, entronca amb Tintoretto per la via dels tints d'un bizantinisme àulic i sever. El Veronese entroncaria amb el senès, cap d'escola de la ciutat rival, potser gràcies a la vibració cromàtica que es custodia en l'art gòtic més encès i sobretot a una suau amabilitat en la qual no cal ser ni gòtica ni renaixentista per reeixir.

Es considera que Tintoretto va passar pel taller d'Andrea Schiavone (1510-1562), 12 pintor d'origen dàlmata, i es va relacionar amb Giovanni Galizzi, actiu a Venècia a partir del 1543 i ja mort el 1565, amb qui s'associa Schiavone el 1544, sustentant uns pactes que es mantenen fins al 1554. Com és habitual en la biografia de molts artistes, la primera època de Tintoretto, sobrenom de Jacopo Robusti (per a d'altres, Comin), ${ }^{13}$ no queda del tot establerta i no es desclou a la perfecció, encara que es revela atractiva la possibilitat d'una concurrència en el taller de Bonifacio de Pitati, que, conegut com a Bonifacio Veronese (Verona, 1487 - Venècia, 1553), ${ }^{14}$ va morir sense fills al barri venecià de San Marcuola. Al seu torn, I'activitat de Bonifaci es relacionà amb la de Palma el Vell, de qui havia estat deixeble.

Es coneix obra signada per Giovanni Galizzi. En aquest sentit, adquireix notorietat una imatge de sant Marc entronitzat entre dos sants del 1547. Les concordances amb Robusti aviat ressalten a partir de pintures com l'esmentada, i s'observa que potser es van separar perquè Galizzi plagiava un molt més genial Tintoretto, per més que advertim que si fou 
aquesta la causa real de la ruptura, en la pràctica és ben difícil de determinar. ${ }^{15}$

Tintoretto treballà a Venècia, on I'art de la pintura i el mosaic havien prosperat des de temps reculats. La civilització pictòrica del color l'apropa a artistes de gran nivell, representants d'un Renaixement que abandona la línia per manifestar-se, cada vegada amb més encert i vistositat, amb les llums de les pinzellades audibles, que poden ser més soltes, més empastades o més foses, però que no deixen d'entendrir les superfícies amb palpitacions gestuals de ritmes diversos que obliguen a recordar l'impacte sobre Emilio Vedova i l'informalisme del segle xx. Tintoretto mirà de trobar el seu lloc en una conjuntura en què no era gens fàcil despuntar. El seu vincle turbulent amb el geni de Tiziano Vecellio (v. 1480-1490 i 1576), el qual s'assenyala ja cap al 1533, obre moltes portes i finestres a la pintura de Jacopo, però cal entendre que aquest és un camí llarg que té anades i retorns, difícil de resumir amb anècdotes, poc o molt atzaroses, o de reduir a una enveja infernal.

\section{Prèvia sobre l'art de Tintoretto}

Alabat com un dels grans mestres de la Venècia del color, ja fos la dels Bellini, la de Giorgione o la de Tiziano, Tintoretto desenvolupa una pel·lícula esmaltada i profunda. Cimabue, més que no pas Duccio, ens en donava la pauta, amb la qual cosa aquest darrer, el pintor de Siena, quedava més del costat $d^{\prime}$ un Tiziano 0 , sobretot, $d^{\prime}$ un Veronese, que, tot salvant les immenses distàncies que els separen dels no menys grans «primitius», no despleguen l'esperit cromàtic bizantí com ho fa Tintoretto al segle XVI i com ho havia fet Cenni di Pepo (Cimabue) al Ilarg del segle XIII. ${ }^{16}$

Sempre fent costat al color com a vector essencial, la pintura de Tintoretto construeix la forma amb uns pinzells valents i s'allibera del dibuix i el contorn obvis per construir i exercitar la força de la taca i entendre la llum com a dissenyadora principal de la imatge. La complexitat neix com un dels reptes principals d'un enginyer dels espais que també es va fer famós per la celeritat amb què enllestia les pintures. De fet, el valor llibertí de la pinzellada, que s'accelera en algunes obres, fa pensar també en la tècnica del non finito, de l'inacabat voluntari i estratègic (o maniera che non finisce) ${ }_{1}^{17}$ de I'inacabat que no ho és realment i que van utilitzar tant pintors com escultors seguint una estela que s'havia ordenat ja en I'obra de I'encara plenament medieval Giovanni Pisano i es consagrà, força més tard, en alguns treballs de Miquel Àngel. Tintoretto crea discurs a partir de la capacitat per esbossar realitats amb entitat pictòrica diversa que naveguen sobre les geu també els estudis generats arran de I'exposició de París (Grand Palais) i Luxemburg: Guillaume Cassegrain, Tintoret. Naissance d'un génie, París, Découvertes Gallimard, 2018. Cassegrain és I'autor també d'una monografia que cal considerar: Tintoret, París, Hazan, 2010. Vegeu en síntesi: «PITATI, Bonifacio, detto Bonifacio Veronese», Francesco Trentini, Dizionario Biografico degli Italiani, vol. 84, Roma, Istituto della Enciclopedia Italiana, 2015, consultable en línia.

15 Robert ECHOLS, «Giovanni Galizzi and the Problem of the Young Tintoretto», Artibus et Historiae, vol. 16, núm. 31, 1995, p. 69-110. Echols ha publicat recentment, en el marc del 500 aniversari del pintor, la monografia: Tintoretto. Artist of Renaissace Venice, New Haven / Londres, Yale University Press, 2018.

16 Encara que pugui quedar fora de tema, aprofito per esmentar la tauleta de la Coronació d'espines de Cimabue, venuda recentment a França, peça que hauria format part d'un políptic dedicat, com a mínim en part, a la Passió de Crist: Rosa AlcoY, «Pinacoteca medieval: un Cimabue a mercat» [en línia], El Temps de les Arts, 5 de novembre de 2019, disponible a https://tempsarts.cat/pinacoteca-medieval-un-cimabue-amercat/.

17 Roland KRISCHEL, «Tintoretto al lavoro», R. ECHOLS i F. Ilchman (eds.), Tintoretto..., p. 75. És important separar, com bé aprecia Krischel, les obres 
que es deixen inacabades i són completades per fills o col.laboradors, i aquest esperit que, sense ser nou, tragina Robusti vers resultats innovadors.

18 No és sobrer recordar el reconeixementa Velázquez, que originaria el 1960 la publicació o figura. Homenaje informal a Velázquez, en el marc de la Sala Gaspar de Barcelona.

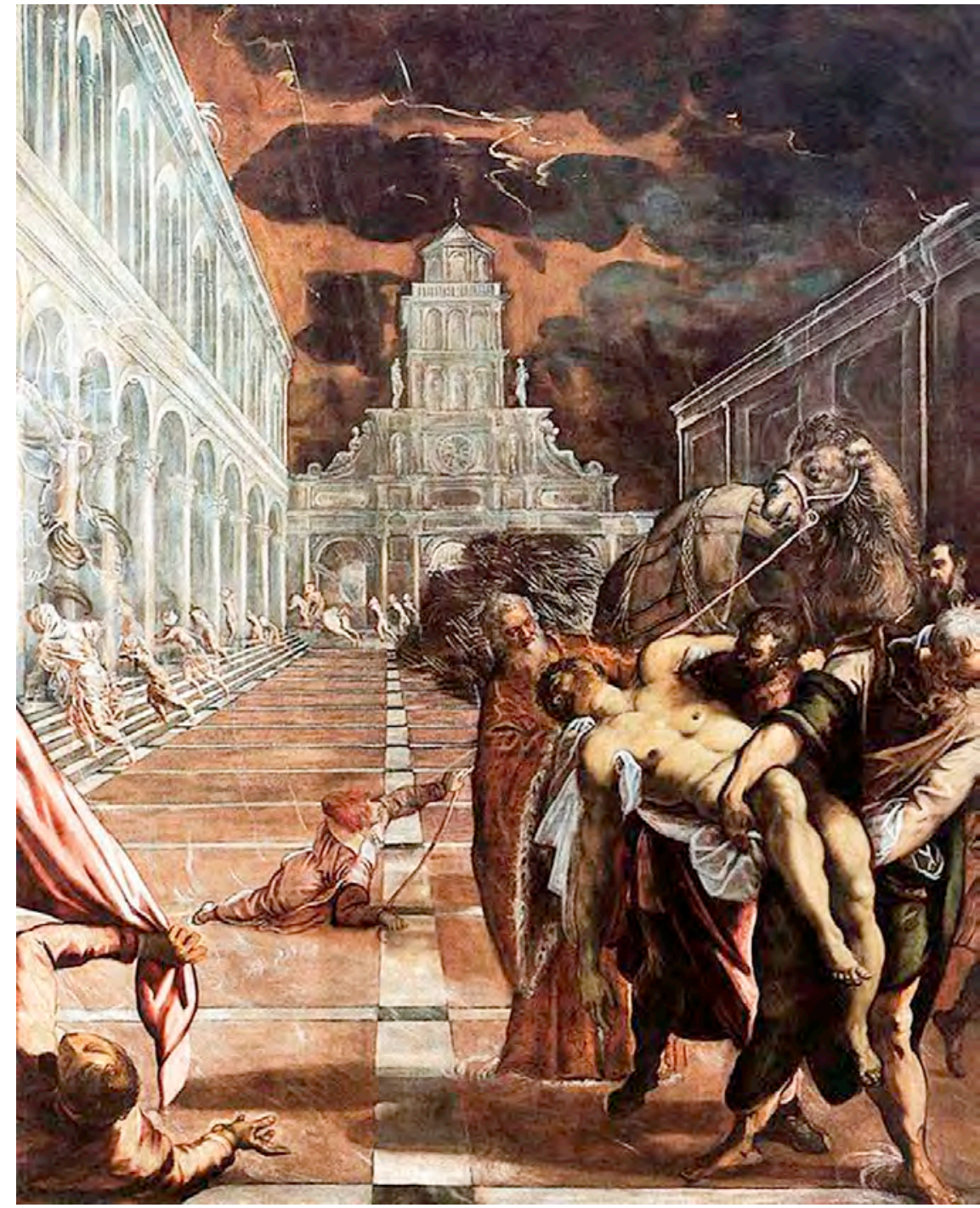

Fig. 1. Jacopo Tintoretto, Trasllat del cos de sant Marc, Scuola Grande di San Marco, Venècia.

superfícies fins a arribar a trencar els motllos més estables i acceptats (fig. 1). El pintor opta per jerarquitzar les densitats de les figures, la seva mateixa consistència, alhora que procura emetre un valor 0 una entitat plàstica específica per a cada fragment de pintura que no es resigna a ser igual que aquell altre fragment que té al costat. Tintoretto ens acosta a un cert informalisme avant la lettre que, lògicament, farà pensar en altres artistes i permetrà evocar també el Velázquez més inquiet i pictòric. ${ }^{18}$ 


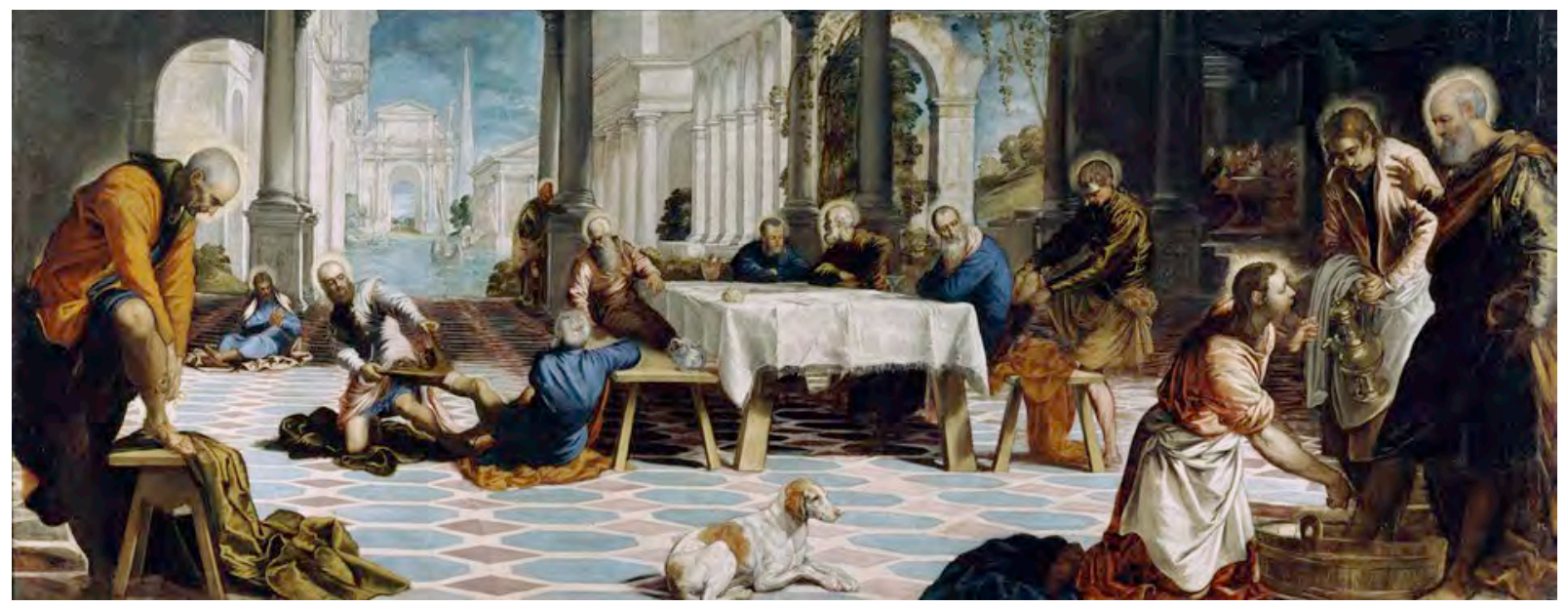

Fig. 2. Jacopo Tintoretto, Rentament de peus, v. 1549, Museo del Prado, Madrid.

Una altra coordenada general que abraça l'art del nostre pintor és la valoració anticipada de l'emplaçament de l'espectador. És ben sabut que Tintoretto avalua el moviment dels qui observen les seves obres i s'hi anticipa per determinar com el nostre desplaçament ha d'incidir en la configuració de les seves pintures, sobretot, és clar, en aquelles que tenen una clara dimensió monumental i en les quals el punt de vista acostuma a ser un vector de reconeixement extraordinari i que, com es pot observar, accentua la versatilitat de les creacions. En aquest sentit, s'ha d'admetre que no pretén fixar l'estructura en un punt inamovible, sinó arriscar al màxim perquè tot participi en un joc visual intrèpid (fig. 2).

Carlo Ridolfi, el primer gran biògraf de Tintoretto, el definiria com a creador d'espectacles, dissenyador de maquetes i de vestits, creador de gags i d'efectes especials. Un artista que ho preparava tot amb models de cera o fang que sabia com articular i il.luminar per assolir els efectes desitjats. ${ }^{19}$ És rellevant per entendre el context en què es treballa que entre 1442 i 1565 es comptabilitzin a Venècia més d'una cinquantena de companyies de teatre, una aposta per l'espectacle i I'espectacularitat que acompanya la ciutat des de tots els angles i racons del seu singular urbanisme. Aquests incentius no podien deixar indiferent un artista que, com altres pintors anteriors medievals o moderns, es veuria implicat molt directament en totes aquestes accions que combinaven una vessant lúdica i popular i una altra de clarament representativa, cerimonial i afiliada als grans poders de la ciutat o la nació.

Al mateix temps que afina les seves habilitats en el camp descrit per I'escenari immens de la Venècia festiva, Tintoretto es presenta com un gran coneixedor del món de l'escultura, creador ell mateix de models arti-
19 En diferents llocs en línia es pot consultar l'obra de Carlo Ridolfi, Le Maraviglie dell'arte, que, editada el 1642, enclou la «Vita di Tintoretto» i les d'altres pintors venecians. També se'n poden consultar diferents edicions modernes i anotades. 
20 Per entendre el paper dels models creats per Miquel Àngel és indispensable el catàleg de Charles DE Tolnay, Corpus dei disegni di Michelangelo, 4 vols., Novara, Istituto Geografico de Agostini, Cassa di Risparmio di Alessandria, 1980. És sabut que Tolnay va dedicar amplis estudis a I'obra de l'artista en tots els seus camps de treball. Vegeu també el conegut volum d'Arnold Hauser, Manierismo. La crisis del Renacimiento y los orígenes del arte moderno, Madrid, Guadarrama, 1965, que veu en Tintoretto el manierista per naturalesa. Vegeu també: Caterina FURLAN, «La fortuna di Miquelangelo a Venezia nella prima metà del Cinquecento», Paola Rossi i Lionello Puppi (eds.), Jacopo Tintoretto nel quarto centenario della morte: atti del convegno internazionale di studi, Collana "Quaderni di Venezia Arti», Venècia, Ca' Foscari, núm. 3, 1996, p. 19-25.

21 R. ECHOLS i F. ILCHMAN (eds.), Tintoretto..., p. 20-21.

22 EdoardoVilLATA, «Gaudenzio Ferrari e la Spogliazione delle vesti al Sacro Monte di Varallo», Arte Lombarda, núm. 145, 2005, p. 76-92. culats que li serviran per experimentar amb el moviment dels volums i les formes humanes. S'acostuma a esmentar el nexe amb el florentí Jacopo Sansovino, però, posats a reconèixer el pes de l'escultura italiana, en un sentit més global cal apreciar les amplituds d’un món de riquesa enlluernadora que havia de reparar obligadament, i així ho va fer, en les aportacions de Miquel Àngel. ${ }^{20}$ Al capdavall, s'ha repetit com un mantra que Tintoretto ens regala amb «il disegno di Michelangelo i il colorito de Tiziano», una frase amb aires metafísics que s'arriba a atribuir al pintor $\mathrm{i}$ que ha fet molta fortuna. És evident que tècnicament aquesta frase ens passarà factura si volem explicar-la amb tot detall, però alhora que oposa, molt gràficament, Ticià a Miquel Àngel, ens endinsa en un problema de la pintura de tots els temps que, al voltant del 1500, condicionaria els uns i els altres.

No crec que Giorgio Vasari es mostrés gaire indecís en el seu judici sobre Tintoretto quan parla de Jacopo com d'un pintor extravagant, capriciós, ràpid i resolt, i el descriu com «Il più terribile cervello che abbia avuto mai la pittura», encara que puc entendre que així es consideri. ${ }^{21} \mathrm{La}$ proximitat artística i cronològica a Tintoretto fa de Vasari pintor un crític que, alhora que aprecia allò que veu, s'ha de veure qüestionat i corprès per una abundància de talent i una imaginació pictòrica que ha d'explicar-se a si mateix si no vol quedar fora de joc. Els seus recels no eviten que degoti en el seu escrit l'admiració per l'existència d'un cervell inigualable. Al seu torn, Ruskin sembla apreciar-ho quan adverteix, a Stones of Venice (1853), que Tintoretto és incomparablement més profund i sever que Tiziano.

\section{Els preparatius de la Passió}

El 1513 Gaudenzio Ferrari ja havia configurat el gran retaule mural de Santa Maria delle Grazie de Varallo, localitat emplaçada entre el Piemont i la Llombardia. Un gran Calvari ordena la programació que, presidida pel Crist a la creu, ens condueix de I'Anunciació a la Resurrecció, tot destacant els temes de la Passió de Crist. Encara que el mestre que signa, Gaudenzius Ferrarius Vallis Siccidae pinxit, no fos el millor de la seva època, ens dona la pauta d'una iconografia encara vigent i ens ajuda a situar la perspectiva normalitzada sobre alguns motius i temes que, com és lògic, admetran variacions múltiples. Tanmateix, ens interessen per advertir que els canvis poques vegades són tan profunds com ho van ser en les propostes de Tintoretto. Molt de la tradició medieval sobrevola encara el cicle de Varallo, per més que les formes puguin ser atribuïdes a un Renaixement ja avançat (fig. 3). ${ }^{22}$ 


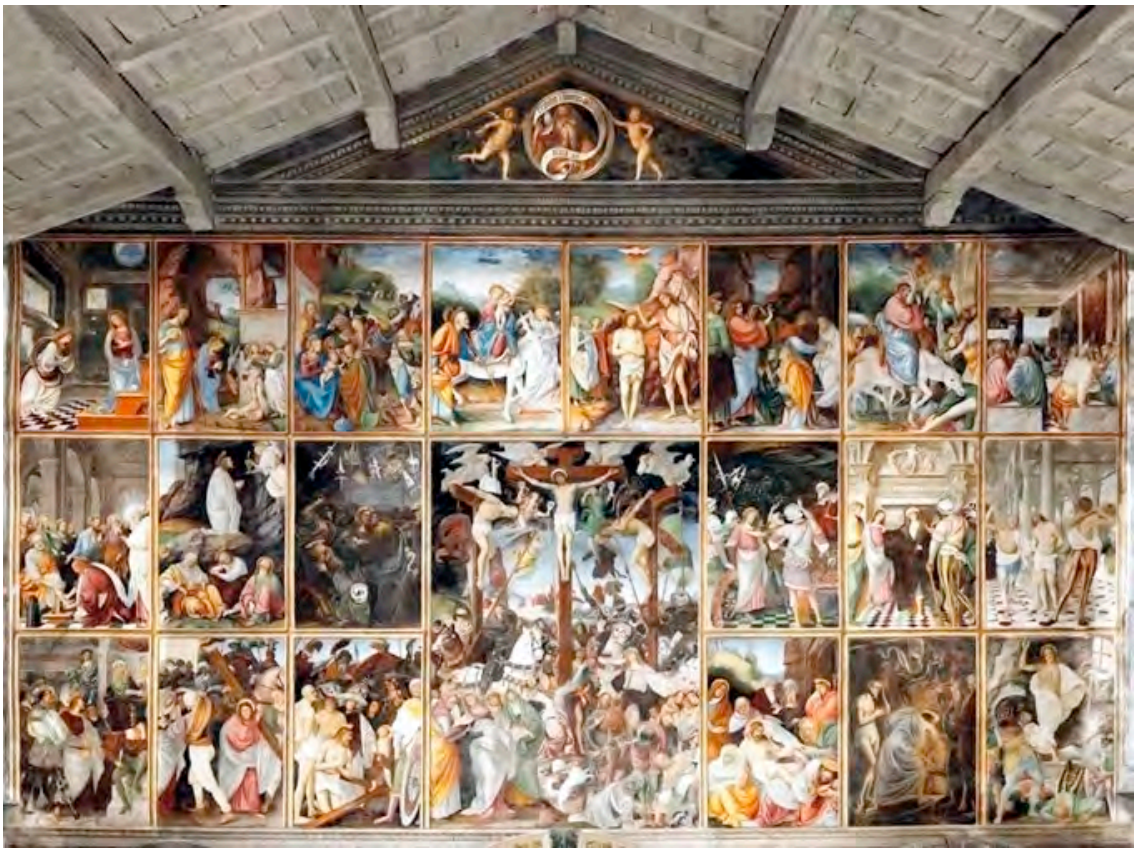

Fig. 3. Gaudenzio Ferrari, retaule mural de Santa Maria delle Grazie de Varallo, 1513.

La gran quantitat d'obres i episodis relacionables amb la Passió de Crist que va pintar Jacobus Tentorettus, anomenat Tintoretto, 'petit tintorer', perquè era fill, com sabem, del tintorer Battista, m'impediran entrar a fons en moltes de les escenes que ens convoquen a reveure un ampli espectre de situacions i temàtiques. El Sant Sopar i altres instants introductoris, anteriors al Judici de Crist, són importants per si sols i caldrà contemplar-los potser massa apressadament. Tot i així, cal tenir-los en compte per entendre el desplegament del discurs que segueix i que va ser creat en diferents etapes de la vida del maestro.

Un dels moments que les teles descriuen amb més eficàcia i potencialitats és el Rentament de peus. Destaca, i molt, la versió que en conserva el Museo del Prado, encara emplaçada en dates prou primerenques de la biografia d'un pintor que no moriria a la seva Venècia natal fins I'any 1594. L'obra ens situa vers el 1549 (figs. 2 i 4). ${ }^{23}$ En aquesta pintura Tintoretto inicia un viatge que no tindrà retorn i que és capaç de subjugar I'espectador. L'interior i I'exterior s'uneixen, i les figures que havien gaudit del Sant Sopar es dispersen o centrifuguen per un espai que és tan immens com ben estructurat. Crea una cadena en què cada nou personatge ocupa un Iloc més inesperat que I'atorgat a aquell que té al costat. Un plausible sant Marc, amb túnica blava i que es podria confondre fàcilment amb Crist, és relegat a un pla Ilunyà que pot ser vist com a inexplicable-
23 L'oli sobre tela té unes mides apaïsades de $210 \times 533$ cm i es vincula a l'església veneciana de San Marcuola, a la qual pertany també un Sant Sopar que serà comentat tot seguit. 


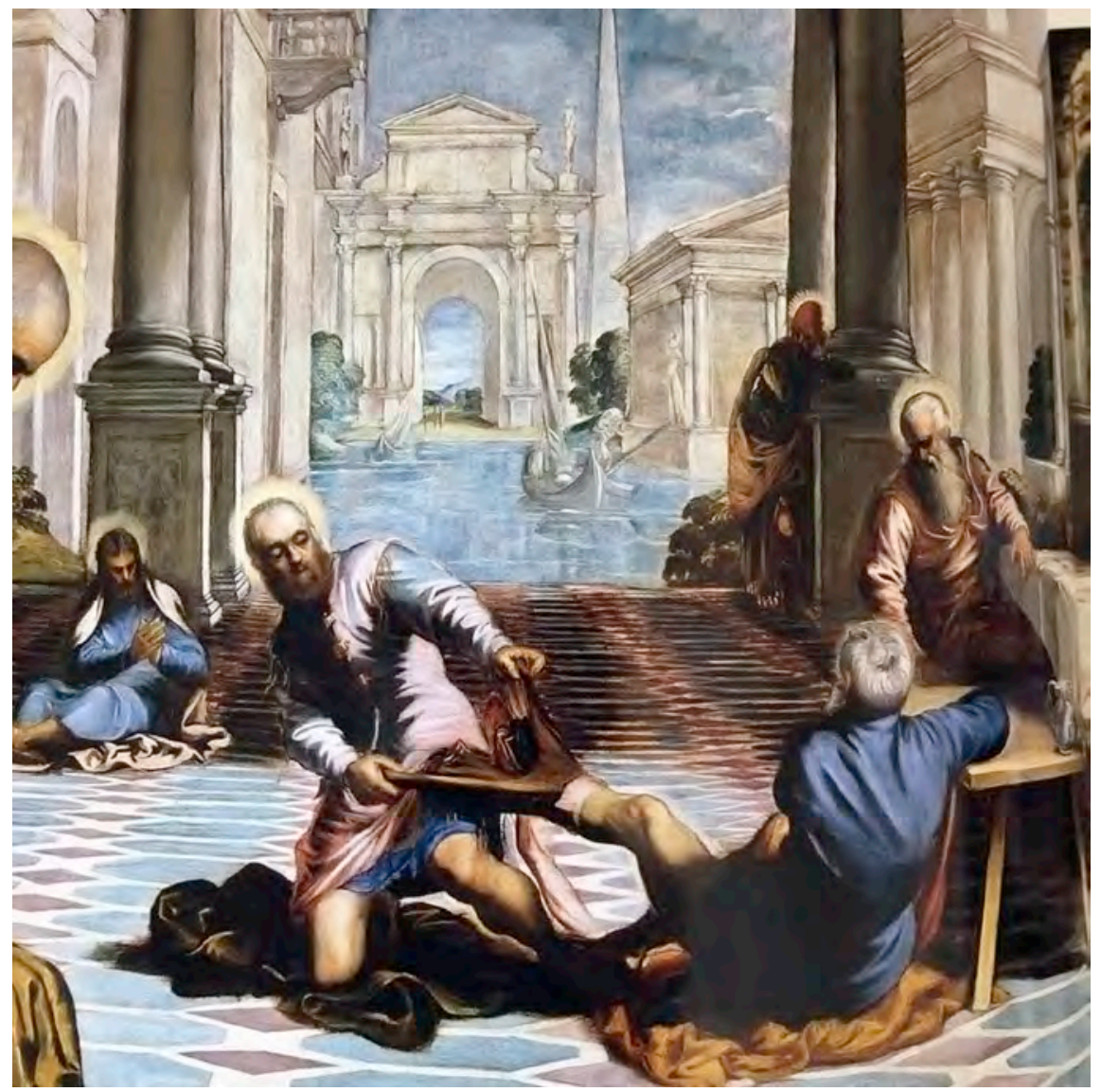

Fig. 4. Jacopo Tintoretto, detall del Rentament de peus, v. 1549, Museo del Prado, Madrid.

ment secundari. La seva persona, asseguda a terra i amb posat orant, romandrà empetitida per la distància, i qualsevol podria pensar que ha de passar quasi desapercebuda (figs. 2 i 4). Tanmateix, es tracta d'un miratge, perquè el color i tota la composició són dissenyats perquè ens hi fixem i no sigui possible badar a I'hora de llegir la pintura i entendre que la seva figura és vital en el discurs. En aquesta direcció col-laboren tant el colossal apòstol que remena una sandàlia, arrecerat a l'esquerra i en primeríssim terme, com aquell que Iluita per desembarassar els peus i les cames d'un company o tercer apòstol, amb una disposició arriscada que permet anar teixint diagonals poderoses que, en aquest cas, detura el gos del primer pla. Això sense menystenir la disposició resguardada de la taula, que dista força del primer terme i que estira la nostra visió vers el fons, alhora que dibuixa una part notòria de l'escenari fent confluir el blanc de les estovalles amb el blanc de les columnates i els arcs del fons. Tot I'espectacle s'ha 
de completar amb la imatge de Crist agenollat que dialoga, a la banda dreta, amb sant Joan, portador de I'aigua, i un sant Pere reticent, ambdós convertits en els seus interlocutors directes. Mentre I'Evangelista para atenció a les indicacions del Mestre, sant Pere té un peu ficat al cubell de fusta, construït amb una tècnica similar a l'aplicada a les velles botes del vi i a les portadores del raïm i també en alguns recipients emprats pels tintorers que recorden molt especialment el que figura en la pintura. ${ }^{24}$ Aquest angle de la tela porta a un segon espai, alçat i dissociat temporalment del primer, on intuïm el cenacle que reuní Crist i els apòstols perfectament compost. ${ }^{25}$ La profunditat de la pintura del Rentament és excepcional, igual que ho és el treball del paviment, que es mou al ritme de I'espectador. Només ho supera tot plegat la coordinació cromàtica, que fa d'aquesta composició alambinada una obra que sembla simple i complaent, però que no ho és. No pretén ser simplement admirable, en efecte, ja que Iluita per ser directament increïble com a realitat pintada. El toc final i poètic el donaran les aigües, les barques que hi suren i les arquitectures clàssiques que ho envolten tot i per a les quals segur que es poden cercar models clàssics i contemporanis, propers al 1500.26

En dates veïnes, una mica abans fins i tot, es pintaria el més discret Sant Sopar de la mateixa església de San Marcuola de Venècia, que ens situa a I'entorn de 1547 i que, segons es pot llegir clarament en la inscripció gravada a la fusta d'un escambell, era del temps de Miser Isepo Morandelo i els seus companys (fig. 5). El tema del Rentament no hi figura integrat perquè ja sabem que es desplegaria després amb autonomia i una grandiositat desmembradora en la tela del Prado. Al Sant Sopar més íntim pren tota la força el grup de Crist amb els apòstols a I'entorn d'una taula rectangular que permet assenyalar un Judes que ens dona l'esquena. Als flancs evolucionen dues dones, que semblen les encarregades de servir el sopar; la de la banda dreta va acompanyada d'una parella d'infants, que obliguen a pensar en la Caritat. El model de San Marcuola es retroba en el Sant Sopar de la Real Academia de Bellas Artes de San Fernando, a Madrid, que insisteix en la composició genèrica, amb àmplies bases, que mostra el traïdor clarament aferrat a la bossa de les trenta monedes dins d'un ambient de calma tensa, que s'interessa per la disposició ordenada de les banquetes de fusta on seuen els comensals i també pel disseny de les lloses del paviment, més notori en el primer cas (fig. 6). ${ }^{27}$ Tintoretto il-lumina amb lluentors groguenques els contorns del cap dels presents, amb una llum que esdevé crucífera en el cas de Crist. Ara bé, si en el primer dels exemples Judes gaudeix d'aquest distintiu, o aurèola, el perdrà en I'obra conservada a Madrid, que va ser retallada possiblement per ambdós costats. ${ }^{28}$

L'església de San Trovaso de Venècia és la ubicació d'un altre Sant Sopar d'ambició considerable, en què el pintor treballarà ja vers el 1563.
24 Vegeu la xilografia reproduïda a Stefania MASON, «Tintoretto Veneziano», p. 41, fig. 32.

25 Només la possibilitat d'emmarcar aquesta pintura hauria justificat perfectament I'exposició que se li va dedicar al Museo del Prado l'any 2007. Remeto novament al seu catàleg: M. FALomir, Tintoretto.

26 Es reconeix en aquest esplèndid escenari el pes dels treballs escenogràfics de Sebastiano Serlio a: R. ECHOLS i F. ILChMAN (eds.), Tintoretto..., p. 12. I dins del mateix llibre: Roland KRISCHEL, «Tintoretto al lavoro», p. 67-68, que aborda el sistema operatiu i els procediments de treball característics de Tintoretto. No oblidem que el pintor es planteja també ara imatges complexes en què atorga el protagonisme als encadenats de figures. El Guariment dels empestats per sant Roc, ja del 1549, és un exemple importanten què il.lumina el terra però deixa el cel de I'estança molt fosc, de manera que crea un ambient que roman clar i en la tenebra a la vegada. La imatge al-lusiva a l'empresonament del sant, també assumida pel pintor, insisteix sobre aquesta visió dels clarobscurs emfàtics que, a parer d'algun autor, com ara Venturi, presagien Caravaggio perquè construeixen les figures $\mathrm{amb}$ una llum aïllant.

27 Molt diferent de la situació atribuïda al Judes de Giotto a I'Arena i, malgrat tot, sembla interessant establir el paral.lel per a un context tan proper a Pàdua. 
28 Les mides són 148,8 $\times$ $297,3 \mathrm{~cm}$.

29 Manuel Trens, La Eucaristía en el arte español, BarceIona, Aymà, 1952, ofereix un repertori general $d$ 'imatges de tema eucarístic. Per als Sants Sopars de I'època més immediata a Tintoretto, vegeu p. 6871 i 95, encara que la mostra sigui limitada.

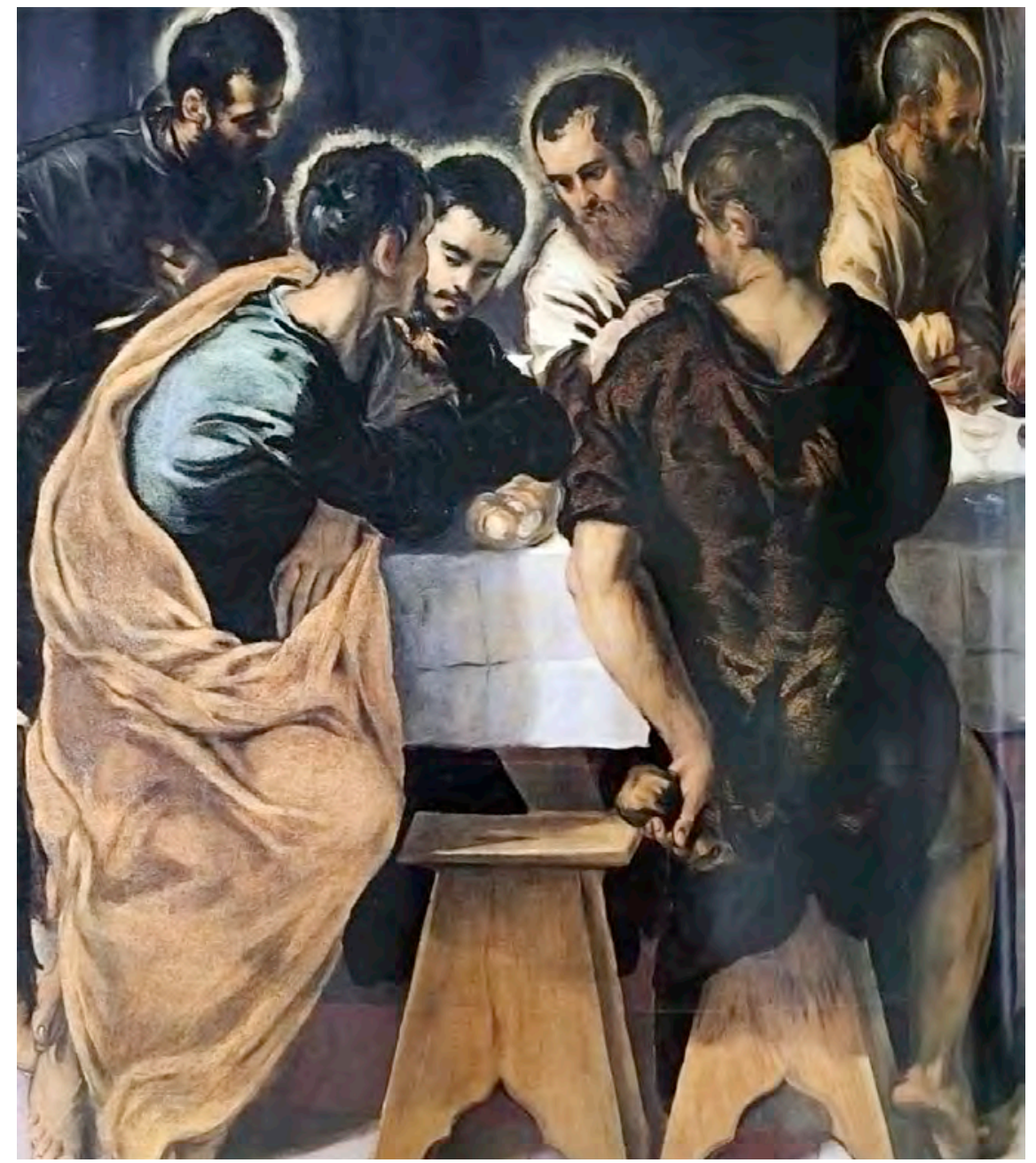

Fig. 5. Jacopo Tintoretto, detall del Sant Sopar de l'església de San Marcuola de Venècia, v. 1547.

Ens demostra que en aquest punt el plantejament ha virat $\mathrm{i}$ ja res no sustenta aquell control tens que podíem admirar a San Marcuola. Alguna cadira caiguda, el moviment sobtat de diverses figures, unes escales que porten a un pis superior i el paper ombrívol i segregat d'un Judes, amb calces vermelles, que es posa en evidència ( $\mathrm{Mt}, 26,23)$, revelen unes coordenades ben diverses que han trasbalsat totalment la naturalesa més aviat ponderada i estable de I'antic episodi, amb la seva repicada dimensió eucarística, malgrat el paper quasi invisible d'una dona que continua amb les seves tasques. ${ }^{29}$ Informats de la deriva de la història, Joan sembla derrotat damunt la taula i la resta no guarda cap compostura cortesana. Sola- 


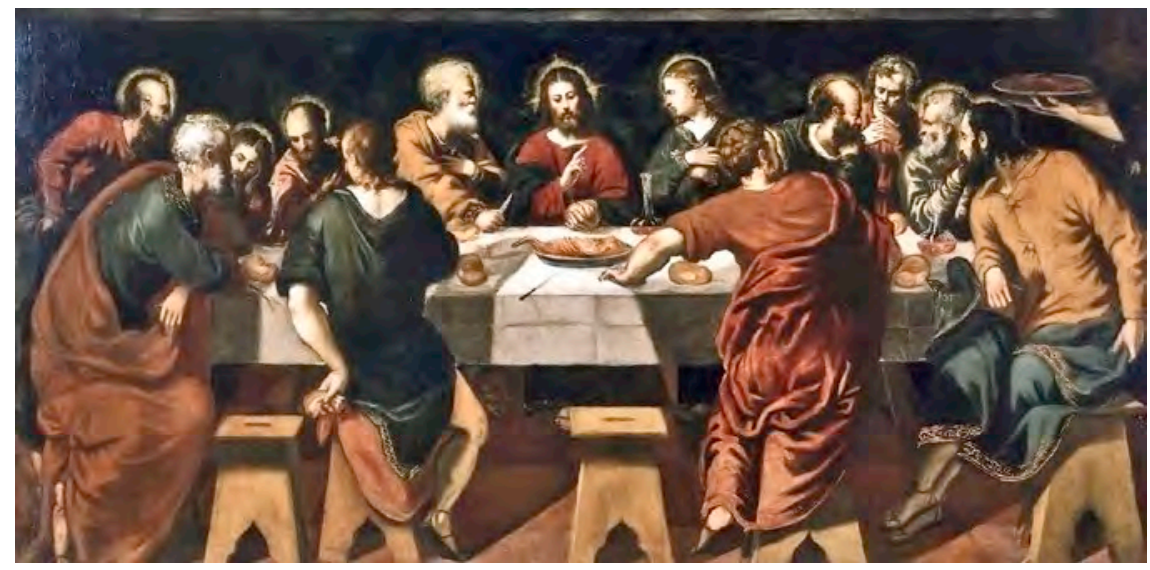

Fig. 6. Jacopo Tintoretto, Sant Sopar de l'església de San Marcuola de Venècia, v. 1547.

ment Crist vol posar pau davant d'un sant Pere neguitós; intenta garantir certa tranquil.litat que ha esdevingut impossible, cosa que pot assumir plenament mentre es prepara el mutis del traïdor. Les dues dones dels flancs, visibles a San Marcuola, s'han convertit en espectres blanquinosos al fons $d^{\prime}$ una imatge que desemboca en una arquitectura molt notòria, que tanca I'escenari i que contrasta amb la visió més aviat severa d'un sopar dissenyat per a pescadors i pobletans que cerquen l'escalfor del braser o s'aferren al vi sense fer compliments (fig. 7). L'espai es perllonga encara, com en el conjunt del Rentament de Madrid, ara amb un arc on advertirem el retall d'un sintètic paisatge que s'ennuvola abans de l'arribada completa de la nit. L'escala amb baranes de fusta té un interès particular i enllaça una filadora espectral, al pla superior, amb el noi que fa de criat i que

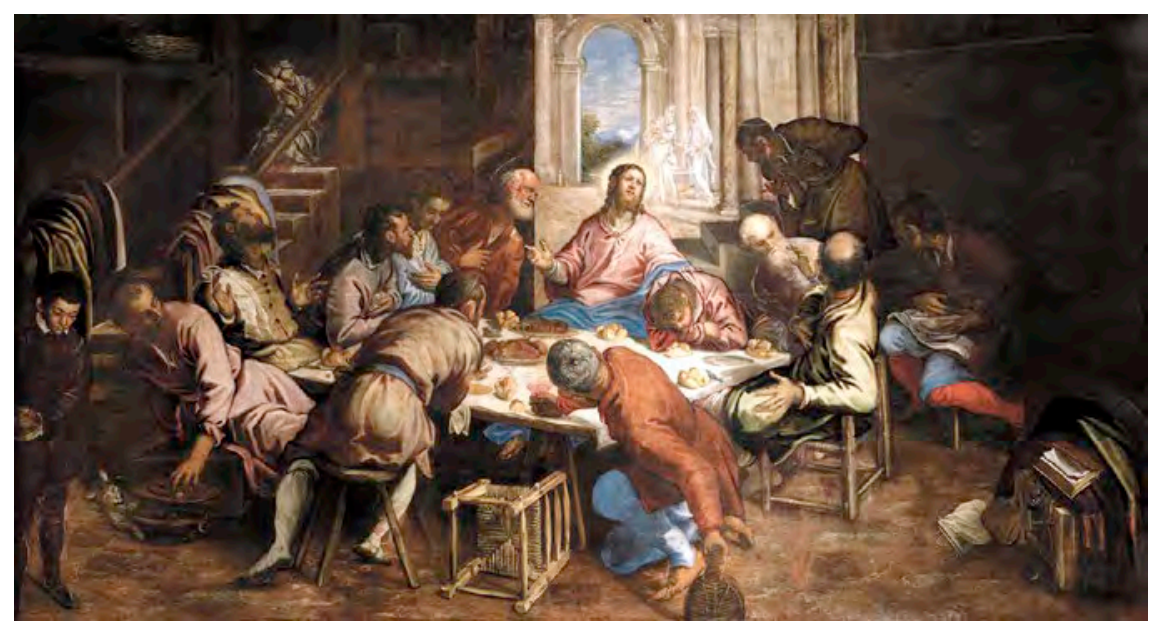

Fig. 7. Jacopo Tintoretto, Sant Sopar de l'església de San Trovaso, v. 1563. 
30 El format torna a ser apaïsat i I'oli sobre tela mesura 200 × 408,3cm, però la precisió perspectiva i la lluminositat del Rentament del Prado donen pas a una visió més austera en tots els sentits.

31 Actualment l'obra fa $208,5 \times 463 \mathrm{~cm}$. Tiziano activa també la proximitat física entre Crist i sant Jaume. Potser per esvair qualsevol possible dubte col-loca la conxa sobre el vestit del segon, però és evident que no deixa marge perquè una mirada atenta pugui caure en l'error.

32 Amb canvis fonamentals en la composició, també es coneix el Sant Sopar de la capella de la Scuola del Sacramento, a San Felice de Venècia i ara a l'església de Saint-FrançoisXavier de París, pintura que, situada segons la inscripció vers el 1559, es considera de Tintoretto amb participació del taller $(240 \times 335 \mathrm{~cm})$.

33 En aquest segon cas, el format és vertical i és clara la tendència a cercar el quadrat $(538 \times 487 \mathrm{~cm})$, només desbordat pels graons que ocupen les figures del primeríssim terme. sembla sorgit d'un altre món més modern que ens podria portar a pintures ja del segle XVII 0, potser, properes al 1600.

El tema del Rentament seguirà el seu curs en una visió més entenebrida de la National Gallery, vers el 1566, en què el tractament de la relació entre Crist i sant Pere recupera la tradició sense deixar de generar actituds i fragments pictòrics que la transcendeixen. ${ }^{30}$ D'una mica abans de San Trovaso i d'una mica després del Rentament de Londres és el Sant Sopar de Tiziano Vecellio del monestir de San Lorenzo de El Escorial, que, realitzat vers el 1563, es considera una obra retallada pels quatre costats. ${ }^{31}$ No som Iluny d'algunes de les opcions de Tintoretto, encara que Tiziano empra en aquesta obra tonalitats més suaus i introdueix alguns motius inesperats que guarneixen el fons amb un paisatge que penetra l'estança. El primer terme es tanca amb una cistella i atuells diversos; un recipient de metall sembla atraure especialment una perdiu viva que, simbòlica o no, s'hi acosta a beure. La disposició de sant Joan i altres detalls fan de l'obra de Tiziano una creació manifestament diversa pel to, pel gest, pel discurs pictòric i, encara, pels detalls de la indumentària d'unes figures que han de comparèixer ben calçades, a diferència del que succeïa al Sant Sopar del 1547, ubicat a la veneciana església de San Marcuola.

Amb una important tradició bizantina al darrere, no hi ha dubte que el tema del Rentament de peus té a veure amb les sandàlies que ja Duccio havia fixat com a expectativa necessària en el seu discurs de la Maestà de Siena (v. 1308-1311), aprofitant models bizantins anteriors. No cal dir que ara I'escena es reestructura i es renova, associada al nou plantejament del Sant Sopar, però sobretot perquè aquest episodi amb entitat pròpia afavoreix, com hem vist al Prado, un plus de moviment i inestabilitat que guia I'espectacle pictòric en tot moment. No oblidem que a Venècia I'episodi del Rentament ja havia sobresortit als mosaics bizantins de la basílica de Sant Marc i que tenia el seu paral·lel, també monumental, a la catedral de Monreale.

EI Sant Sopar es repeteix, sense haver de sortir de la ciutat dels canals, a Santo Stefano $(221 \times 413 \mathrm{~cm})$, vers el 1570 (fig. 9), ${ }^{32}$ i a la Scuola Grande di San Rocco, de la qual Tintoretto era membre des del 1565, ja vers el 1579-1581, on I'escena assolirà les dimensions més grans (fig. 8). ${ }^{33}$ Tant el primer com el segon fan palès l'interès de Tintoretto per l'espai, que permet regirar la taula, ara baixa, de forma arrauxada, i trencar radicalment amb l'antiga opció, igual que es farà en algun episodi de les Noces de Canà. Es podria conjecturar que el moble ja no es pot situar en el pla paral·lel a la superfície pictòrica sense avorrir el pintor. El context guanya cada vegada més amplada i profunditat i relliga escenaris a diferents nivells, on escales i paviments ordenen un contorn complex en què 


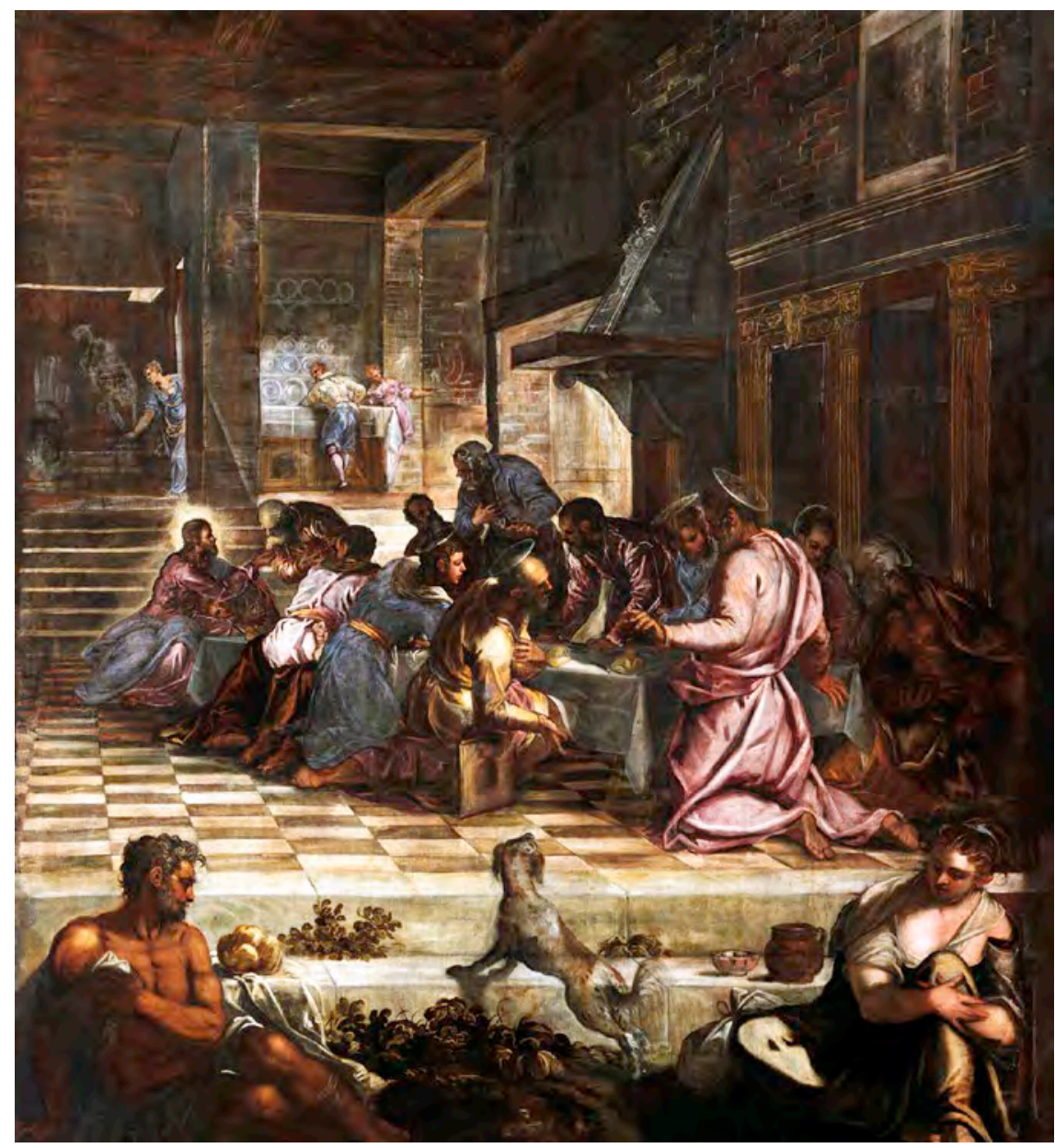

Fig. 8. Jacopo Tintoretto, Rentament de peus, v. 1566, The National Gallery, Londres.

observarem també altres figures que aparenten viure alienes als fets principals. L'atrafegament interior i exterior del grup dels apòstols continua i els deixebles semblen, més que no pas estables sobre un terra fix, moure's de manera compassada, gairebé com si anessin en una barca i el mar els dictés la posició o, en algun cas més extrem, com si estiguessin vivint a l'epicentre d'un terratrèmol. La centralitat de Judes s'ha dispersat dins d'aquest vaivé, on descobrim la confluència generosa de diversos tipus d'aurèoles i on fins arriba a ser difícil localitzar la imatge de Crist. Cal buscar-lo, perquè Tintoretto I'ha amagat, tot i que és la figura més notable en lluminositat. El pintor juga amb l'espectador i amb la seva cultura per tal d'engrescar la part interactiva que pertoca a tot observador eficaç. Els servents i els darrers termes són tractats amb una evident sofisticació que fa abstracció del 


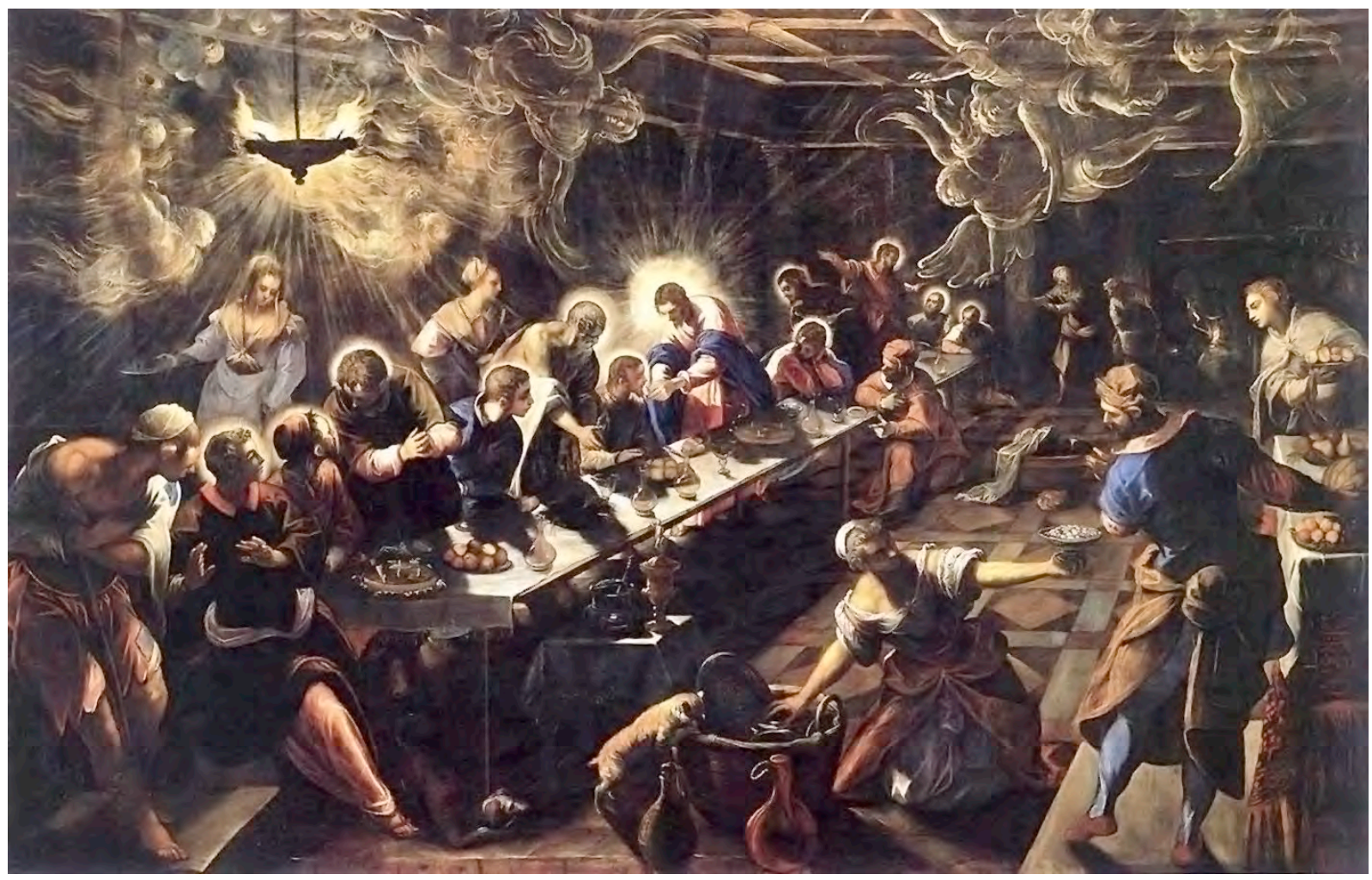

Fig. 9. Jacopo Tintoretto, Rentament de peus de l'església de Santo Stefano de Venècia, v. 1570.

més concret per envair les estances, ja majestuoses des del punt de vista tectònic, amb l'atmosfera i el dinamisme que la llum incentiva — podríem dir encén-, en graduar-se i inspirar ombres i punts de claror magnificada. Aquestes troballes condueixen finalment al Sant Sopar de San Giorgio Maggiore de Venècia, datat el 1592-1594, on la realitat convergeix amb una dimensió celestial. A I'esquerra, el sostre s'omple de presències etèries amb un impacte similar als dels transparents, envoltats d'àngels i nuvolades, d'algunes catedrals importants. En fi, la nebulosa de la llum, I'advertim natural com la dels transparents o artificial com la de la làmpada, no pot competir amb la brillantor solar de l'aurèola de Crist i algunes de les resplendors que generen els apòstols.

Finalment, només un esment de l'Oració a l'hort (v. 1578-1581), que ens retorna a la Scuola Grande di San Rocco (fig. 10). Es tracta d'una composició que ajusta diferents nivells de realitat i prepara les escenes següents. Els apòstols adormits són descoberts a la llum de I'àngel saltironejador, que porta el famós calze a un Jesús endormiscat. Falta encara I'acceptació quan un dels apòstols, que ha de ser sant Pere, s'adona de la 


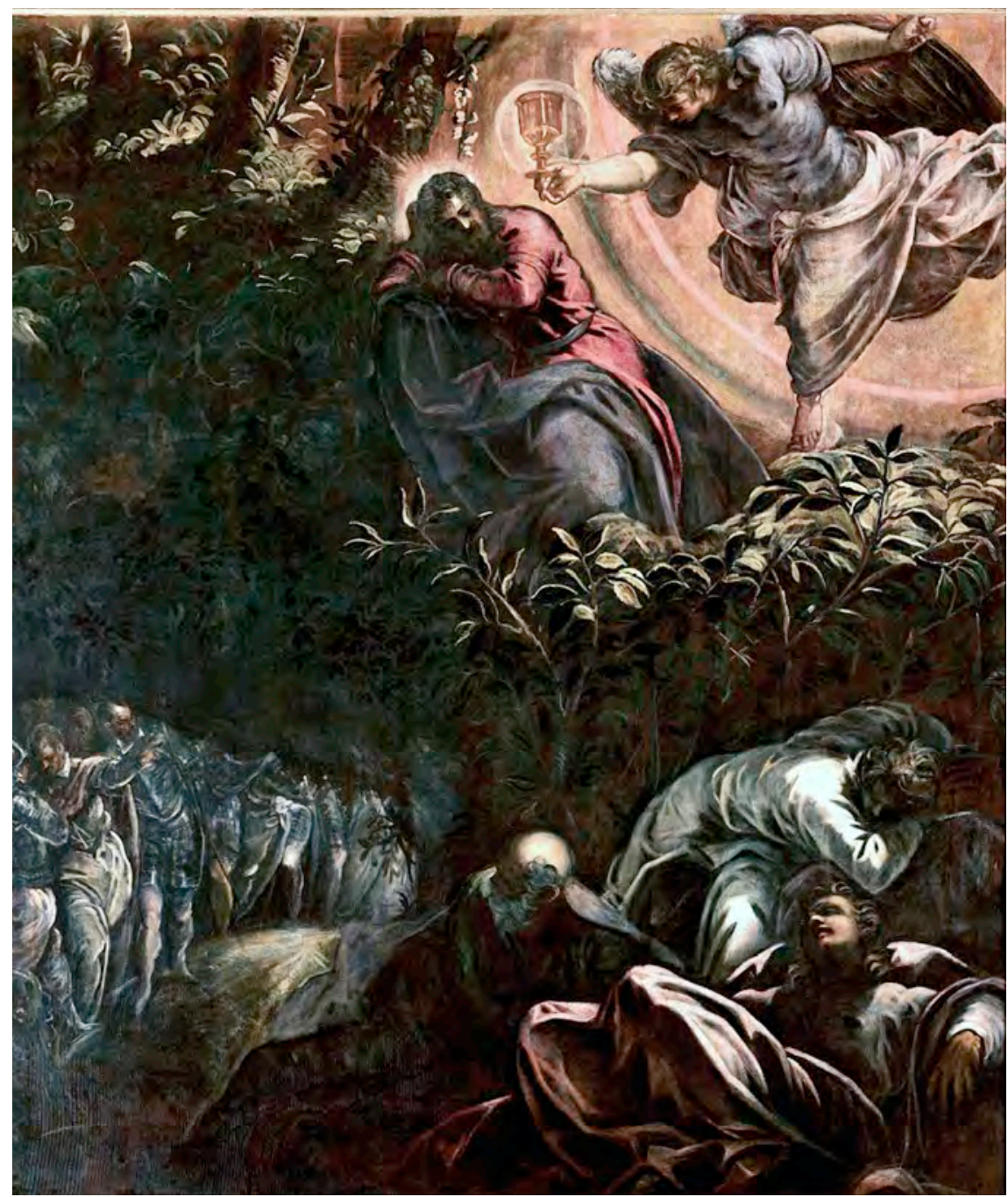

Fig. 10. Jacopo Tintoretto, Oració a l'hort, v. 1578-1581, Scuola Grande di San Rocco, Venècia.

processó àmplia d'espectres que s'acosta, plausiblement sorollosa, a l'escenari. Aquesta corrua imprecisa on es poden distingir els soldats i la imatge d'un Judes que assenyala ja, amb lleugeresa insòlita i incongruent, la imatge de Crist, pronostiquen fàcilment el Greco, sense encarnar-lo encara. No debades, s'atribueix a aquest darrer una admiració incondicional pel Robusti, a qui considerava, com a responsable de la tela de sant Roc i els empestats, autor de la millor pintura del món. Les figures semblen dansar un ball macabre que, congelat en la pintura, transfigurarà en pocs instants el reposat escenari de I’Oració de Crist. El pintor treballa 
34 Gianmario GuidarelLi, "Le Scuole Grandi veneziane nel XV e XVI secolo: reti assistenziali, patrimoni immobiliari e strategie di governo», Mélanges de l'École française de Rome, núm. 123-1, 2011, p. 59-81. URL: http://journals.openedi tion.org/mefrm/664; DOI: 10.4000/mefrm.664.

35 No entraré en el tema del funcionament de la Scuola; vegeu: F. Tonon, "Devotissima Scuola e Fraternità del Glorioso Missier San Rocco. Registro delle Parti, 1488-1549», Quaderni della Scuola Grande Arciconfraternità di San Rocco, núm. 9, 2003, i treballs sobre els temps successius del mateix autor.

36 Es tracta d'un oli sobre tela de $147 \times 199 \mathrm{~cm}$ de la National Gallery de Londres, comentat a Chistopher BAKER, Canaletto, Londres, Phaidon, 1994, cat. 16, p. 62-63.

37 Reproduït a R. EchOLs i F. ILCHMAN (eds.), Tintoretto..., p. 13, fig. 11. aquí des d'una maduresa plena que fa que la pintura combregui amb les formes que cal acaronar i subratllar de manera diferenciada. Ho fa atent als detalls i a les intensitats amb uns resultats immillorables. Destaquem el protagonisme de Judes en el relat, quan assenyala I'indret, com una de les claus figuratives que empeny el drama amb tarannà forçós.

\section{La Passió a la Sala dell'Albergo de la Scuola Grande di San Rocco}

Les escoles de Venècia, Scuole di Devozione o Scuole Grandi, van fixar-se a la ciutat proliferant com a centres d'activitat religiosa i artística fonamental, com a llocs de trobada on els ciutadans de determinades zones 0 barris de la urbs es congregarien, ja fossin patricis o pertanyents a les classes populars. La més antiga és I'anomenada Scuola Grande di San Teodoro, que aniria seguida de les de San Giovanni Evangelista, San Rocco, San Marco, Santa Maria della Carità, la Scuola dei Carmini i la Scuola della Misericordia. ${ }^{34}$

Per al nostre tema ens interessa especialment la Scuola Grande di San Rocco, que havia estat fundada el 1478 en un edifici que estava en construcció el 1477 (fig. 11). ${ }^{35}$ Una de les famoses vistes venecianes de Canaletto, en què el Dogo fa la visita de I'església i la Scuola dedicada a sant Roc, vers el 1735, mostra la festivitat de San Rocco celebrada al davant de I'edifici de la Scuola, ${ }^{36}$ el 16 d'agost, per glorificar un sant patró que havia de protegir els habitants contra les plagues i epidèmies que afectaven amb cruesa, cíclicament i funestament, les aglomeracions humanes de tot Europa i amb especial intensitat les més prominents pels seus ports. Al fons destaca l'edifici decorat amb garlandes i amb pintures diverses que es penjaven a l'exterior i que sempre van tenir un paper en una Venècia molt figurativa que dotava els exteriors dels edificis d'importants pintures murals. Al primer terme observem la continuïtat de l'interès per la commemoració "antipestífera» i comunitària, ja molt temps després de la seva construcció, i decoració interior i de les pestes d'avançat el segle XV. No deixo en I'oblit que Tintoretto ja havia dedicat atenció a san Rocco quan pintà les tasques guaridores del sant dins I'església que porta el seu nom. ${ }^{37}$ Van passar uns vuit anys perquè el 1557 el consell de la Scuola decidís invertir dos-cents ducats en la decoració de l'anomenada Sala dell'Albergo, i encara uns quants més perquè, arribat ja el 1564, es completés la decoració del sostre que finançaven els membres de la institució. A tal efecte es va obrir un concurs que cridava a participar-hi els pintors residents a Venècia, els quals havien de Iliurar un projecte per a l'oval cen- 


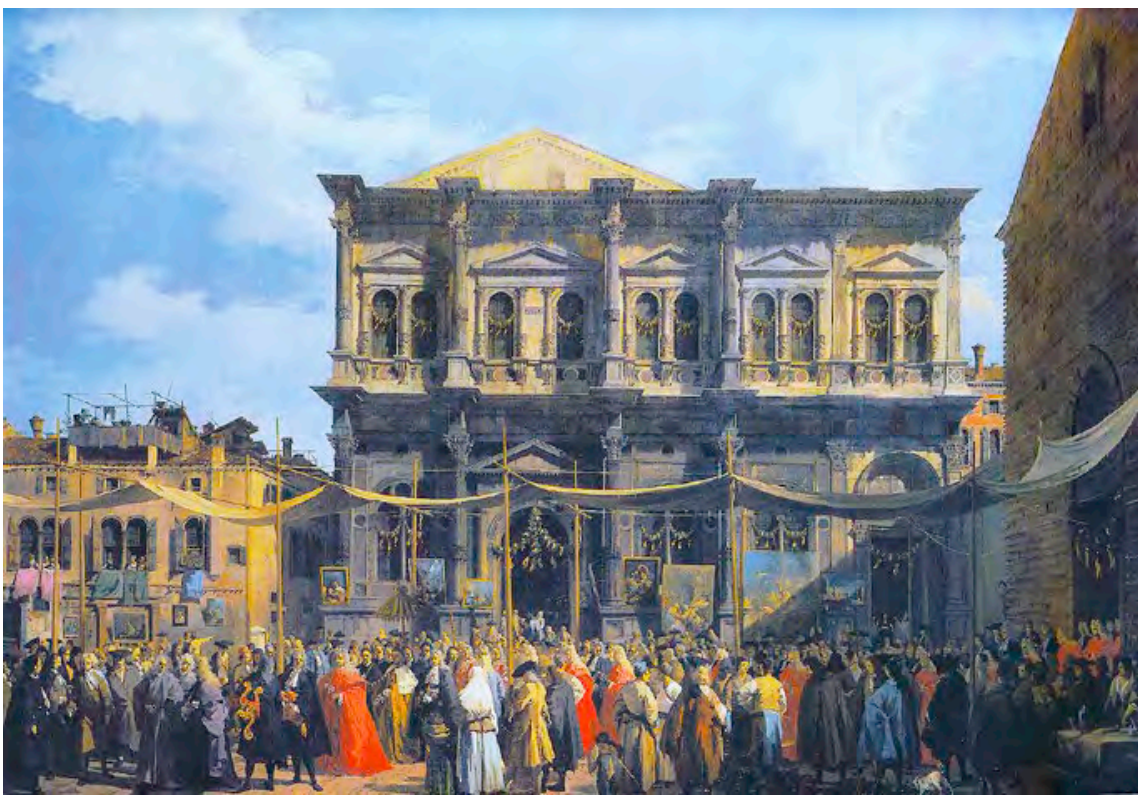

Fig. 11. Canaletto, Visita a l'església i Scuola Grande di San Rocco, v. 1735, National Gallery, Londres.

tral del sostre de l'estança esmentada. Hi havien de participar Paolo Caliari, II Veronese, Lo Schiavone, Il Salviati, Federico Zuccaro i Jacopo Robusti, Il Tintoretto. Vasari explica que Tintoretto, immers en el concurs que havia d'escollir la millor proposta, va pintar la Glorificació de sant Roc com a obra completa i perfecta, en lloc de limitar-se a fer l'esbós que se li demanava. Aquesta pintura va ser col-locada a la Sala dell'Albergo a I'espai assenyalat. Trencant I'esquema plantejat per al concurs, Jacopo Tintoretto hauria decidit aplicar la política de fets consumats i fer ofrena del quadre, sense compensació. A més, s'oferia a concloure I'obra si així ho desitjaven els patrons de San Rocco, i es declarava satisfet amb aquestes condicions (fig. 12). Tancava el text de la proposta tot dient: "Io Jachomo Tentoretto pintor contento et prometo ut supra». ${ }^{38}$

Les pintures que el 1464 Tintoretto va fer per al sostre de la Sala dell'Albergo de la Scuola Grande di San Rocco el convertien en el pintor «oficial» de la institució. Poc més tard arribava a nous pactes amb els seus responsables i del 1565 al 1567 va decorar els murs d'aquest celebrat ambient. Més endavant no desisteix en la tasca d'omplir de grans teleri altres espais imponents de la famosa Scuola, que abasten tota mena de temàtiques religioses amb una inventiva i una capacitat que confirmaven el que ja era manifest des dels anys quaranta. Òbviament, la seva mateixa fama desbordaria els murs de l'edifici i assoliria fites remarcables per tota
38 Existeixen diferents treballs monogràfics sobre la pintura de Tintoretto a la Scuola: vegeu les notes anteriors i Rodolfo Pallucchini i Mario BrunetTi, Tintoretto a San Rocco, Venècia, LeTre Venezie, 1937; Francesco VALCANOVER, Jacopo Tintoretto and the Scuola Grande of San Rocco, Venècia, Storti, 1986. Més enIlà de la monografia estricta, podeu veure: Tom Nichols, Tintoretto. Tradition and Identity, Londres, Reaktion Books, 1999, amb un ampli estat de la qüestió i dos capítols dedicats a San Rocco (p. 148-237), precedits d'una introducció sobre el pintor i els artistes de la seva època, la cultura literària veneciana i els seus encàrrecs i comitents. 
39 La Glòria del santés un oli sobre tela de $240 \times 360 \mathrm{~cm}$ que s'envolta d'altres pintures, entre les quals destaquen les quatre estacions de I'any, considerades del mateix 1564, sempre olis sobre tela amb diàmetre de $90 \mathrm{~cm}$. S'hi afegirien, a més, altres al-legories dedicades a les Scuole de sant Joan Evangelista, la Misericòrdia i la Caritat, I'Esperança i la Fe, sant Marc, sant Teodor, santa Felicitat i les santes Bondat i Liberalitat, totes de $90 \times 190$ $\mathrm{cm}$.

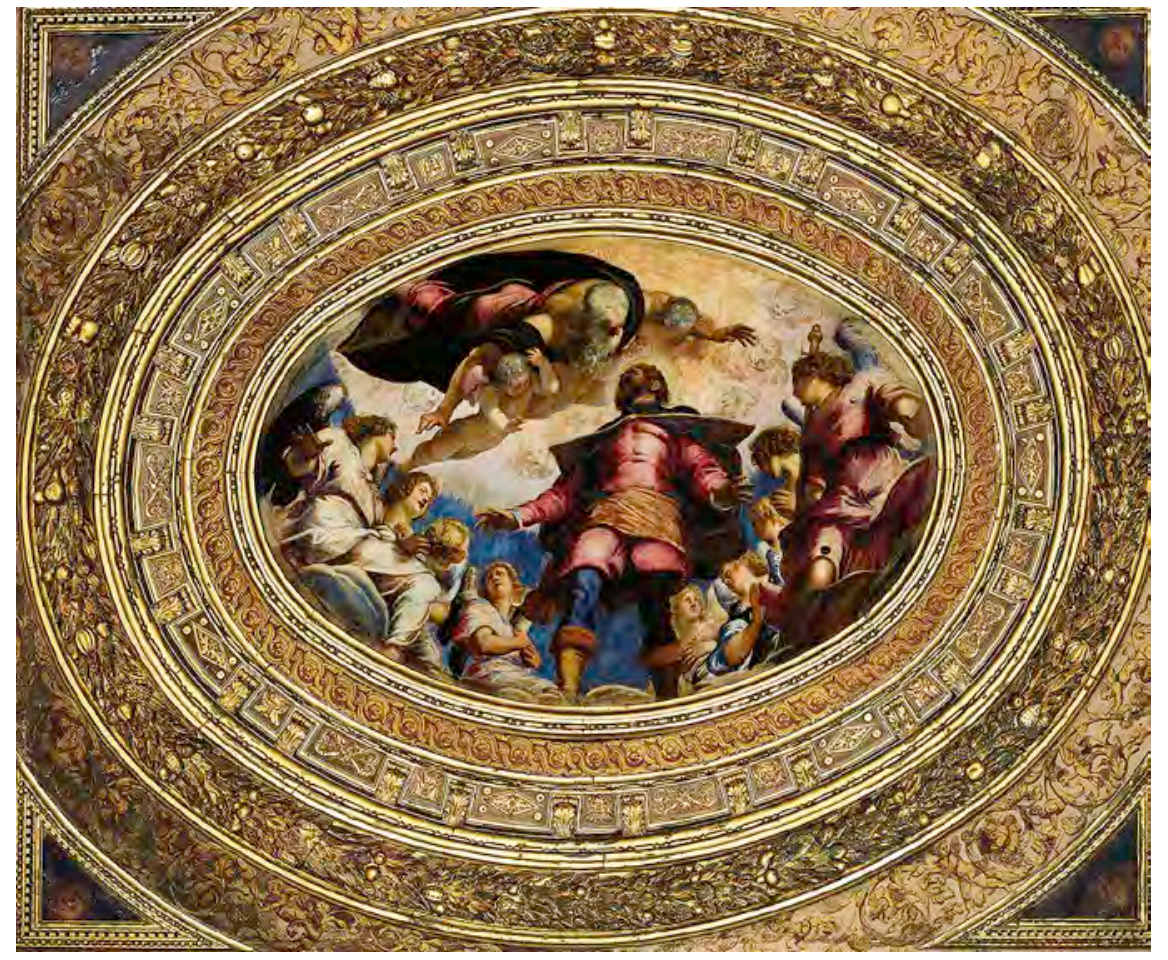

Fig. 12. Jacopo Tintoretto, Gloria di san Rocco, Scuola Grande di San Rocco, 1564, Venècia.

la ciutat. El primer capítol a la Scuola Grande va ser, tal com he assenyalat, I'oval dedicat a San Rocco in Gloria (fig. 12), però la resta de I'espai havia de centrar-se en la Passió de Crist, que és el tema en què ens fixarem. La conversió de San Rocco glorificat a la manera d'un nou sant Francesc sobrevola aquest programa, si bé ara pararem més atenció a altres aspectes. $^{39}$

\section{El Judici de Crist davant Pilat}

Tintoretto va assolir l'èxit amb la seva iniciativa i els anys següents, 15651567, es faria càrrec en primer terme, com ja indicava, dels murals que havien d'omplir els murs de l'estança, uns murs que el mateix Tiziano Vecellio cobejava però que el primer ja havia dotat d'un sostre convenient. La tela del Gran Calvari seria la primera d'executar-se, el 1565, com a mural principal, visible des del mateix accés a la sala. A la paret oposada se situarien el Crist davant Pilat, de $515 \times 380 \mathrm{~cm}$, I'Ecce Homo $(260 \times$ $390 \mathrm{~cm})$ i el Camí del Calvari $(515 \times 390 \mathrm{~cm})(\mathrm{fig} .13)$. 
Reconstruirem el fil narratiu per advertir la forma que Tintoretto va adoptar per transcriure la Passió, encara que cal tenir sempre en compte que el Calvari va ser pintat abans de crear les altres pintures de I'estança, amb l'excepció del sostre, és clar. Per començar, observem que s'evita la lectura d'esquerra a dreta i s'imposen unes coordenades singulars que honoren el cos de I'Ecce Homo com a imatge central, anivellada a les imatges de devoció. El Crist coronat d'espines supleix en part la funció que abans s'hauria pogut atorgar a un Baró de Dolor. És obligat, però, revisar primer, a la recerca de I'esquema cronològic, el Crist que davant de Ponç Pilat és transformat en una mena de columna humana lluminosa (fig. 14). Venturi, en un estudi del 1929, el definiria com a fantasma de llum. És cert que la imatge del Déu-home serà repetida tres vegades en aquesta part del mural, de maneres molt diferents, i també ho és que el Jesús que més límpidament i excelsament sobresurt és el de l'escena que comparteix amb Pilat, amb intensitat dramàtica i espiritual aplicada a fer rellevant la seva divinitat. ${ }^{40}$ L'espai que ocupa el fa prevaldre, és ben clar, com l'ésser diví que és i el contraposa a la dimensió humana que s'esplaia prou intensament en les escenes anteriors i en la subsegüent, a les quals em referiré més endavant.

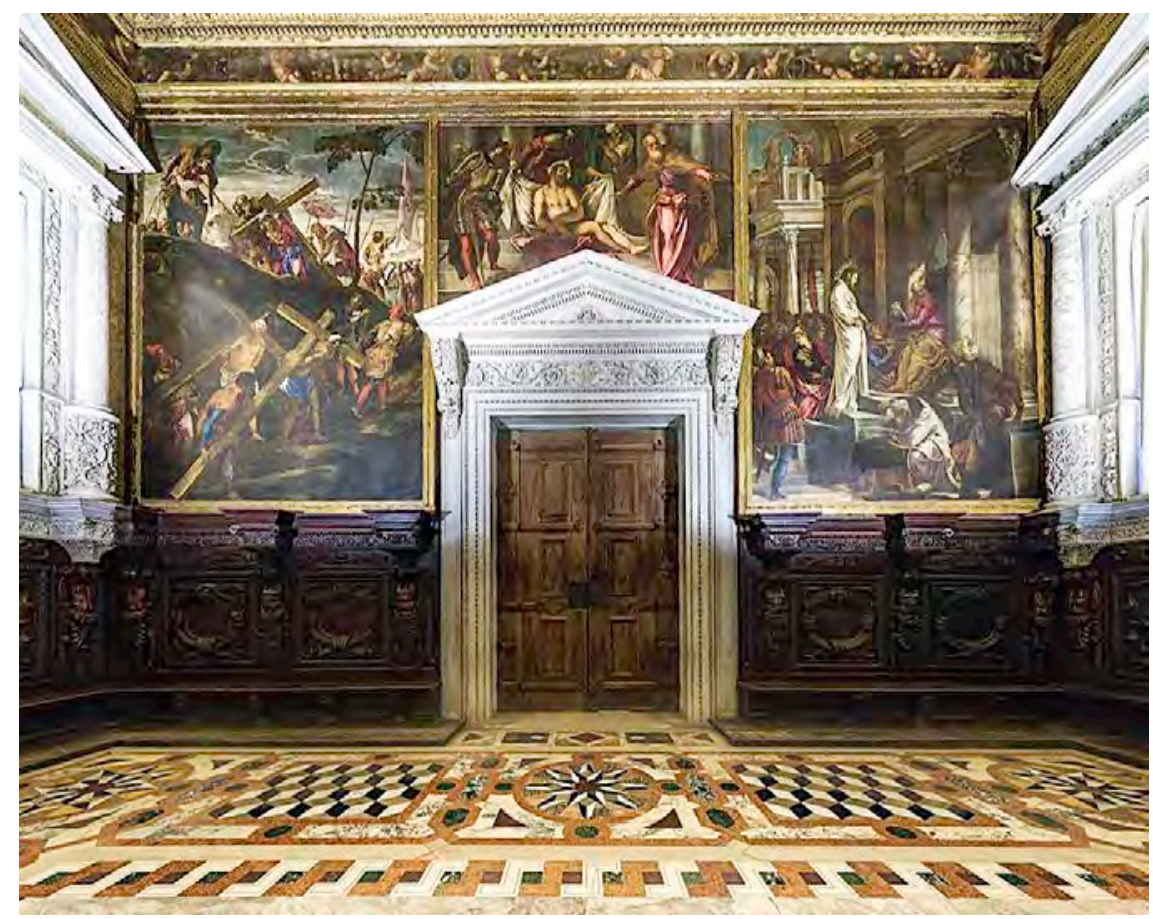

Fig. 13. Jacopo Tintoretto, Sala dell'Albergo, Scuola Grande di San Rocco, Venècia.
40 Calia partir dels Evangelis: Mc 15, 2-20; Lc 23,3-25; Jn 18,33-19,6, però es reconeixen també altres fonts que enriquien la cultura religiosa del pintor. 


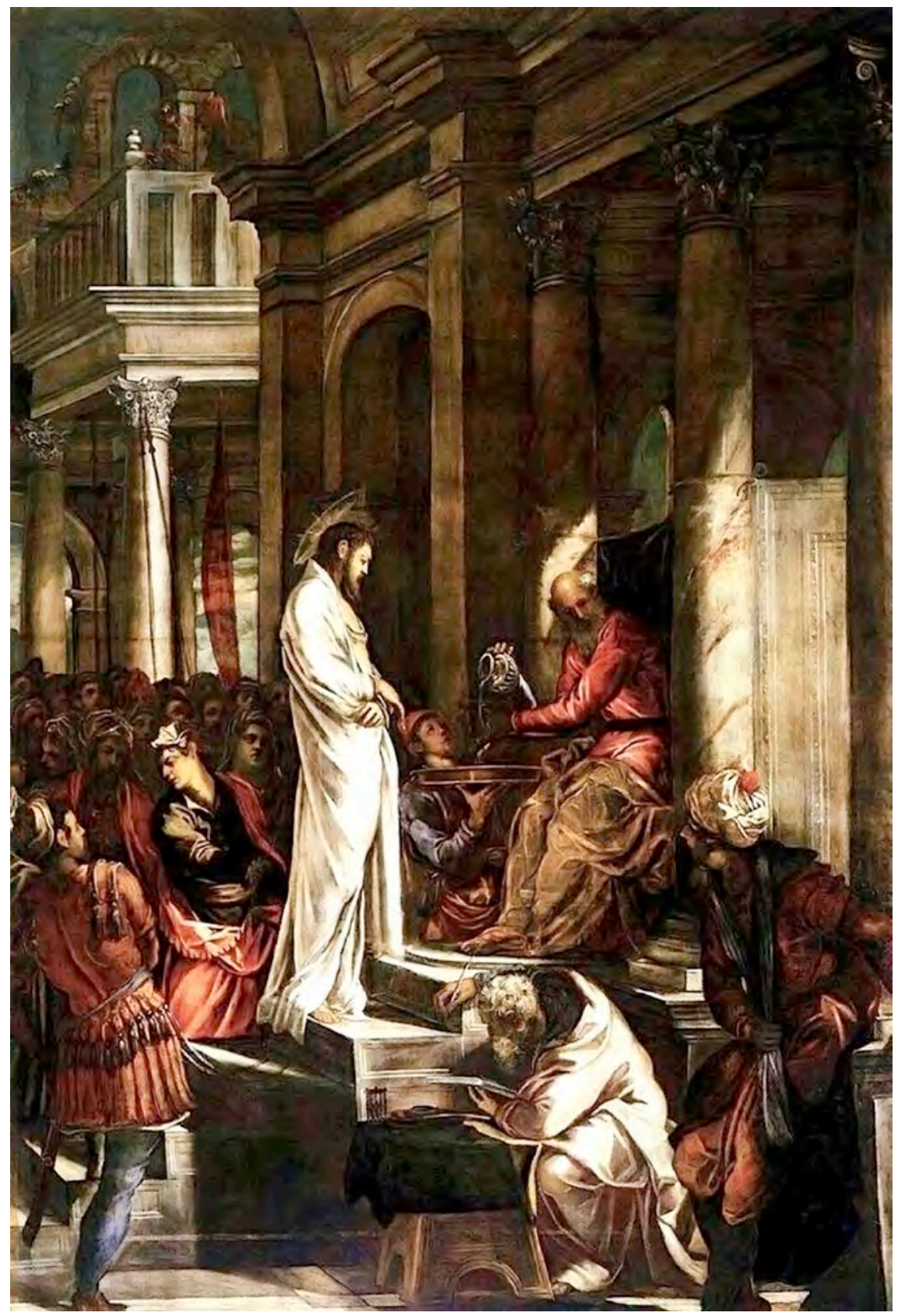

Fig. 14. Jacopo Tintoretto, Crist davant de Pilat de la Sala dell'Albergo, v. 1566, Scuola Grande di San Rocco, Venècia. 
Si ens centrem en I'episodi de Pilat, advertirem que Crist és déu abans de ser home, perquè és un déu encarnat. S'han fet comparacions, degudes ja als treballs de Tietze, de De Tolnay o de De Vecchi, amb creacions d'Albrecht Dürer, en particular amb la Petita Passió. ${ }^{41}$ Els gravats d'inicis del segle XVI, així com algunes propostes de Hieronymus Bosch, per exemple, situen Crist en un pla inferior al que serà ocupat per Pilat o, si més no, quasi al seu mateix nivell, cosa que assenyala sovint el caràcter adolorit i humà del protagonista, per més que Dürer destaqui I'alçada del reu i comprometi la prioritat del personatge entronitzat. Tintoretto crea més distància entre ambdós actors principals i eleva clarament Crist abillat de blanc, que, tot i romandre un esglaó per sota del pla ocupat per Pilat, sobrepassa gairebé en un cap el romà. El governant de testa nua fa una ullada al costat esquerre, alhora que s'afanya a rentar-se les mans sense mirar, amb l'ajut d'un servent sol-lícit que alça la mirada i exerceix des de baix la tasca d'aquari, amb un posat necessàriament artificiós però elegant. Crist s'aixeca com un pilar inamovible i persuadeix doblement, per la blancor de les teles —al.lusives tant a la seva innocència com a la seva dimensió divina - i per la determinació amb què es planta davant de Pilat i la resta dels assistents, que són nombrosos. Un altre punt que cal considerar és la seva projecció sobre I'obra del Greco, que passa per Venècia el 1567-1568. Entre altres pintures, cal tenir en compte L'espoli de la catedral de Toledo (v. 1577-1579), malgrat el canvi espectacular de color en el Crist, que vira del blanc a un vermell intens (fig. 15a). Alguna cosa hi ha que el converteix en conseqüència dels experiments venecians que el portaran, pas a pas, a La Resurrecció del Museo del Prado, al voltant de 1597-1600 (fig. 15c). En aquesta darrera obra, el Crist diví del Greco, despullat i aeri, amb un evanescent cos antropomorf, sense pes ostensible, branda una bandera alba on es desplega la mateixa idea agençada per Tintoretto en I'anterior vestit immaculat de I'Albergo. Es pot apreciar que el venecià ha deixat visible el pit nu de Crist, el qual travessen, creuades per davant, les mateixes cordes que també li Iliguen les mans. Les barbes són llargues i arrissades, igual que els cabells. El nimbe és transparent i executa amb destresa la forma tradicional del plat eteri que ha de qualificar la testa més sacralitzada. ${ }^{42}$ L'estendard es combina amb el mantell rosa que voleia i que torna a recuperar les fondes tonalitats venecianes, per damunt dels cossos dels soldats que el ressuscitat centrifuga amb la seva força ascensional. ${ }^{43}$ La figura de Déu Pare, literalment enfundat en blanc, torna a ser capital al Baptisme de Crist del Greco (fig. 15b) i facilita la possibilitat d'ampliar un cercle de Ilarg radi que també toca, per exemple, la divinitat resplendent de L'enterrament del comte d'Orgaz. ${ }^{44}$

Abans d'insistir en la repercussió del tema, és interessant valorar un altre Crist davant de Ponç Pilat que conserva el Museo Civico de Belluno
${ }^{41}$ Hans TieTze, Tintoretto, the Paintings and Drawings, Londres, Phaidon, 1948. També es comenta a Carlo BERnARI, Pierluigi DE VECCHI, La obra pictórica completa de Tintoretto, Barcelona, Noguer, 1974 (1970).

$42 \mathrm{~S}$ 'ha dit que el blanc podria ser una al.lusió al vestit dels folls. És evident que aquesta foIlia divina no té equivalent terrenal possible i que és la llum la que avala el seu significat i la seva raó de ser. El galileu porta el vestit blanc després de la visita a Herodes, que, ja amb aquest indument, I'envia a Pilat perquè dicti la sentència (Lluc, 23, 11).

43 Miguel Falomir (ed.), Jacopo Tintoretto. Actas del Congreso Internacional Jacopo Tintoretto, Madrid, Museo Nacional del Prado, 2009.

${ }^{44} \mathrm{M}$ 'estalvio fer la llista dels precedents, però em sembla evident el nexe que es vol establir entre el Pare Etern, I'Ego sum lux mundi i el Crist emplaçat davant Pilat. 

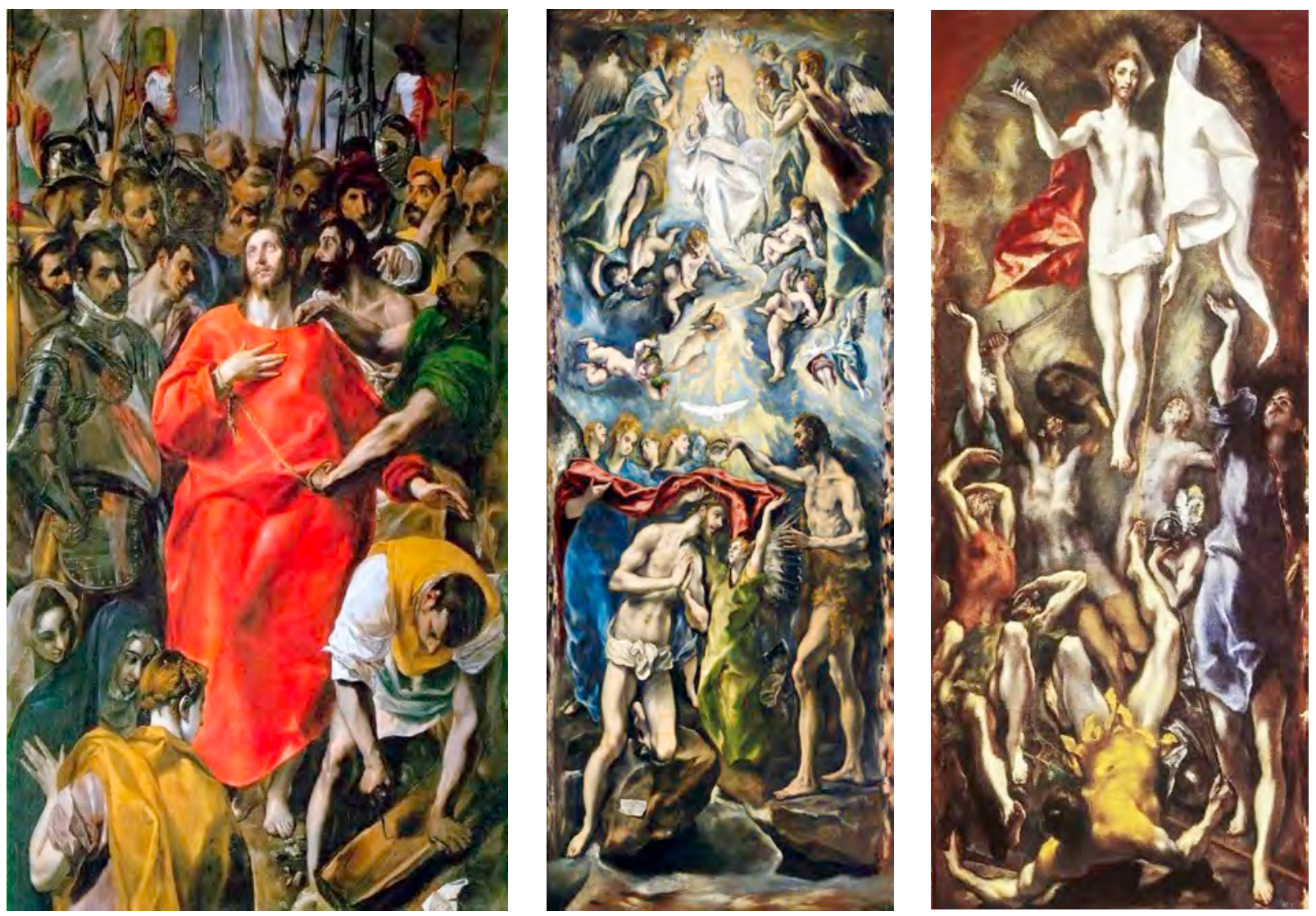

Fig. 15. a, b, c. El Greco, Espoli de Crist de la catedral de Toledo, v. 1577-1579, Baptisme i Resurrecció de Crist, v. 1597-1600, Museo del Prado, Madrid.

(fig. 16) i que s'ha vinculat en algun moment a l'activitat de Domenico Tintoretto, fill de Jacopo i germà de Marietta i Marc, també pintors. L'admirable tensió aconseguida a San Rocco no ha persistit aquí, i el cap il.luminat de Crist a la manera del pare no millora la conclusió. L'innocent compareix ajupit, fins una mica pesarós, davant d'un Pilat que, vestit ricament, domina I'escena amb nitidesa i té I'aparença més de dux, 0 poderós de l'època en context venecià, que d'antic prefecte romà de Judea. El servent que s'ocupa del gibrell on va a parar l'aigua del rentament sembla tan distret com el mateix Pilat, la qual cosa fa pensar que és un veritable miracle que l'aigua de la gerra no caigui on seria inconvenient. Aviat advertim que no és ell qui se n’ocupa, com passava abans, sinó un segon servidor del prefecte, ben concentrat en el que fa. En tot cas, el recurs ha perdut intensitat $i$ altivesa $i$ una densitat desitjable que no mancava en cap moment a l'escena de la Sala dell'Albergo. L'assaig es disper- 


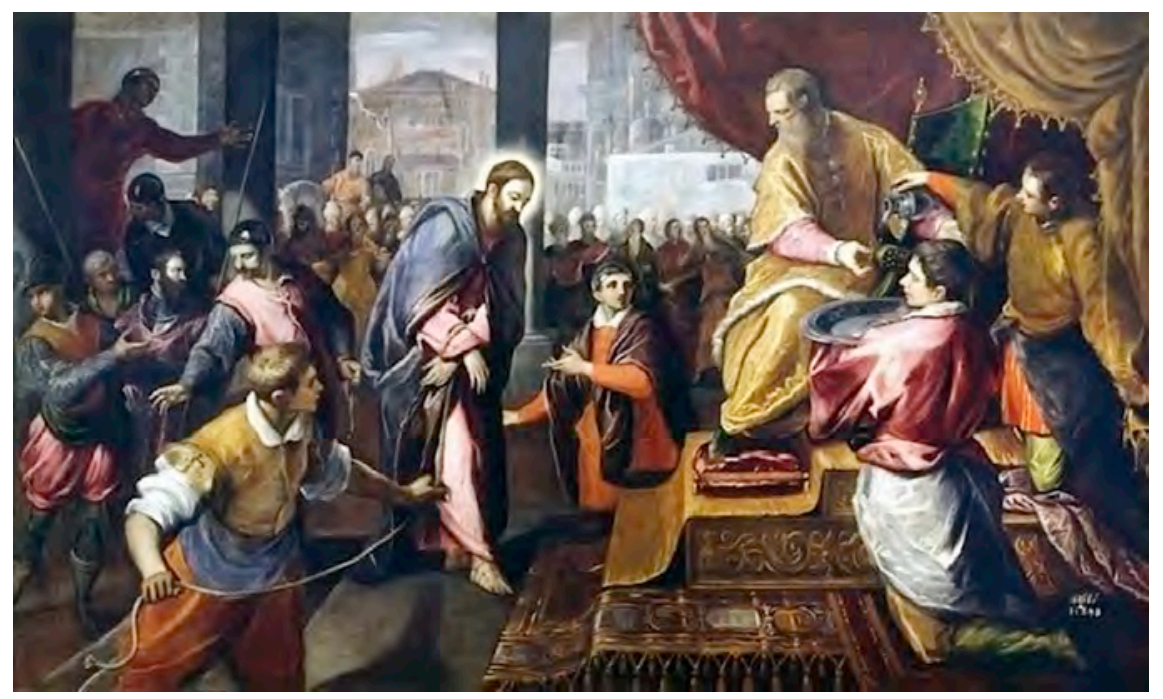

Fig. 16. Domenico Tintoretto o taller de Tintoretto, Crist davant de Pilat, Museo Civico de Belluno.

sa ara sense gaire necessitat d'amoïnar-se per coordinar dues accions en una. En contrapartida, pren protagonisme individual el noi que condueix Crist Iligat de mans amb la corda, per bé que I'esquema minva el verisme de I'acció quan descriu una distància exagerada entre ambdós que, com a tal distància, Tintoretto havia explotat amb lucidesa en altres circumstàncies. En fi, sense que es pugui dir que la pintura és un fracàs, allò que era subtilesa majestuosa en I'exploració de la distància en obres com el Rentament de peus del Prado, s'ha esvaït en nom d'unes estratègies que criden més l'atenció, en alguns aspectes, que el missatge essencial de la pintura. Això es posa de manifest també en comparar el quadre, que no deixa de tenir atractiu, amb I'excepcional creació de San Rocco, on Crist rutilava al centre visual de la pintura, malgrat trobar-se escorat a l'esquerra, enfundat en la seva indumentària blanca, que insisteix amb voluntat tautològica en la seva puresa i centralitat. És a dir, el color i la disposició aconsegueixen centrar la idea i la capitalitat del protagonista, que, si bé és envoltat d'ombres i personatges que no veiem del tot, entona cromàticament amb l'escala que li dona suport i li fa de peanya, amb la columna del fons, que a més redunda sobre la seva verticalitat, tan austera com astuta, quasi d'estàtua columna, i, finalment, amb la figura del personatge assegut, que pensa i escriu amb una ploma, convertit en notari que dona testimoni d'allò que està passant. La complexió i disposició $d^{\prime}$ aquest subjecte voluminós del primer terme reprodueix el mòdul d'un evangelista, i no em puc creure que no sigui de manera buscada. En con- 
45 Lionello PupPI, «Andrea Schiavone nella bottega...», per la clara relació que es pot establir entre ambdós.

46 Fundació de Federico Zeri, catàleg en línia: www. fondazionezeri.unibo.it/it. seqüència, el blanc determina una diagonal en la tela que talla pel mig la figura de Jesús i obliga a fixar-hi la vista. Al seu voltant els colors són densos i revelen les tonalitats carmins i vermelloses amb algun discret blau que, com algun altre apunt Iluminós que ensopega amb el mur de fons, contribueix a aclarir tímidament el vestit i la calba de Pilat, al qual es diria que ja li pesa massa la decisió que ha pres. Andrea Schiavone (Zara, 1510 - Venècia, 1563), amb orígens dàlmates i, en I'obra que comentaré, amb una clara propensió al Tiziano originari de Pieve di Cadore (Belluno), ens brinda un Crist davant Pilat que opta per escurçar totes les distàncies i fa de la mirada entre un vell jueu i Crist una forma d'abandó que expressa un Pilat gran i derrotat i que, malgrat els erminis que vesteix, ha de plegar-se al crit de les masses (fig. 17). ${ }^{45}$ Crist torna a vestir de vermell, però el negre s'apodera també del seu indument i de la zona que ocupa el personatge que té al costat dret.

Al taller de Tintoretto es deuen altres escenes vinculades al tema de Pilat i que fan cap a la Flagel/lació de Crist. Del període 1585-1590 cal atendre la que es conserva al Kunsthistorisches Museum de Viena, també apropada en alguna ocasió al seu fill Domenico (1560-1635). Un cas alternatiu remet a uns Improperis d'escola de Tintoretto, genèricament considerats així al catàleg de Federico Zeri. ${ }^{46}$ No hi insisteixo perquè ens allunyen clarament de I'escenari creat per al Crist davant Pilat de San Rocco, per bé que puguin recordar altres moments de la Passió i servir de transició a creacions anònimes o de l'escola del pintor. La Coronació d'espines de Tiziano Vecellio, a Munic, ens situa ja a I'entorn de 1570 i, al meu parer, és just recordar-la ara pel paper o contrapunt que hi haurien posat els models definits per Tintoretto a San Rocco (fig. 18). Remeten efectivament a les decoracions de la Scuola Grande, els draps blancs que cobreixen el cos de Jesús, assegut sobre unes escales, mentre els botxins criden i remenen pals de canya al seu voltant, així com el soldat que s'aferra a una atxa poderosa de doble tall, però sobretot ho fan les tonalitats profundes $i$ pseudobizantines del color.

Per unes altres vies és interessant cercar els indrets anteriors en què el color blanc dels draps que embolcallen Crist fou una constant i on es mantindrà. Pot fer servei el Baró de Dolor d'Andrea Mantegna (1431-1506), conservat a I'Statens Museum for Kunst de Copenhaguen (fig. 19), que s'esplaia en una idea que també va ser del gust de Giorgio Schiavone (1433 o 1436-1504). Aquest darrer resulta força original quan cobreix el cap i les mans de Jesús amb les robes blanques i el perfila amb els ulls tancats. No té res d'estrany que els draps siguin blancs i que les situacions afins vagin evolucionant paral-lelament a aquesta temàtica votiva que emplaça Jesús entre la mort i la resurrecció. Si cerquem imatges del Fill vestit de 


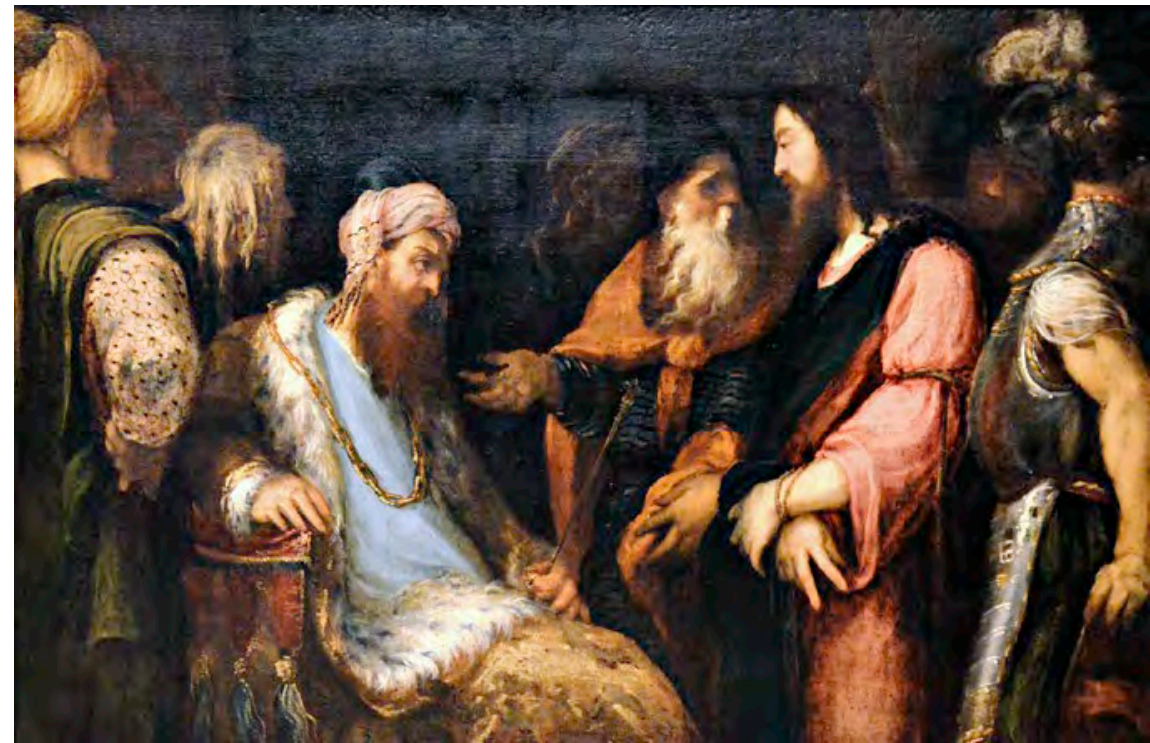

Fig. 17. Andrea Schiavone, Crist davant Pilat, v. 1585-1590, Kunsthistorisches Museum,Viena.

blanc davant de Pilat, observarem que la rutina més estable no és cobrir-lo amb un mantell blanquinós, i menys encara amb un d'immaculadament blanc (fig. 20). L'exemple més espectacular que recordo d'ús del blanc es troba al Crist davant Pilat (fig. 2la) de la Maestà de Duccio (v. 13081311) per a la catedral de Siena, que, tanmateix, no preval com a color del vestit de Jesús en totes les escenes dedicades al Judici de Pilat, i la túnica del captiu és, en I'escena del Rentament de mans de I'obra senesa, íntegrament vermella. Ludovico Mazzolino (Ferrara, 1480-1528) retornarà sobre I'hàbit blanquinós de lleu tonalitat blavosa, i Pontormo, a la Certosa del Galluzzo (Florència) (fig. 21b), crearà un mural de Gesù davanti a Pilato, devers 1523-1525, en què és el gris el que sembla dominar la figura d'una pintura massa danyada per fer-se una idea perfecta dels colors. ${ }^{47} \mathrm{En}$ tot cas, el nexe amb Tintoretto no sembla gaire probable, tampoc el que portaria a un singular Hans Holbein el Vell (1460/65-1534), que generalitza el blanc per a les figures de tots els presents indiscriminadament. Només les carnacions i els caps, també les lloses del paviment, trenquen la grisalla lletosa del Crist davant Pilat de la Graue Passion vinculada a Holbein el Vell. El recorregut sempre es podria estirar, considerant el blanc que empra Ludovico Mazzolino per a un Crist, del Fitzwilliam Museum, a Cambridge, que Pilat es mira des de molt amunt, per arribar a concloure que aquesta opció fou una possibilitat, més que no pas una obligació, sempre amb el benentès que a Crist arrestat se'l va vestir prou freqüentment de vermell 0 de rosa ataronjat i de molts altres tons, sense haver $d^{\prime}$ abundar-hi
47 En tot cas, sempre es pot recórrer a la versió realitzada per Jacopo Ligozzi a partir de Pontormo, que conserva la Pinacoteca de la Certosa, on les teles del Crist tornen a apuntar a la tonalitat blavosa. 


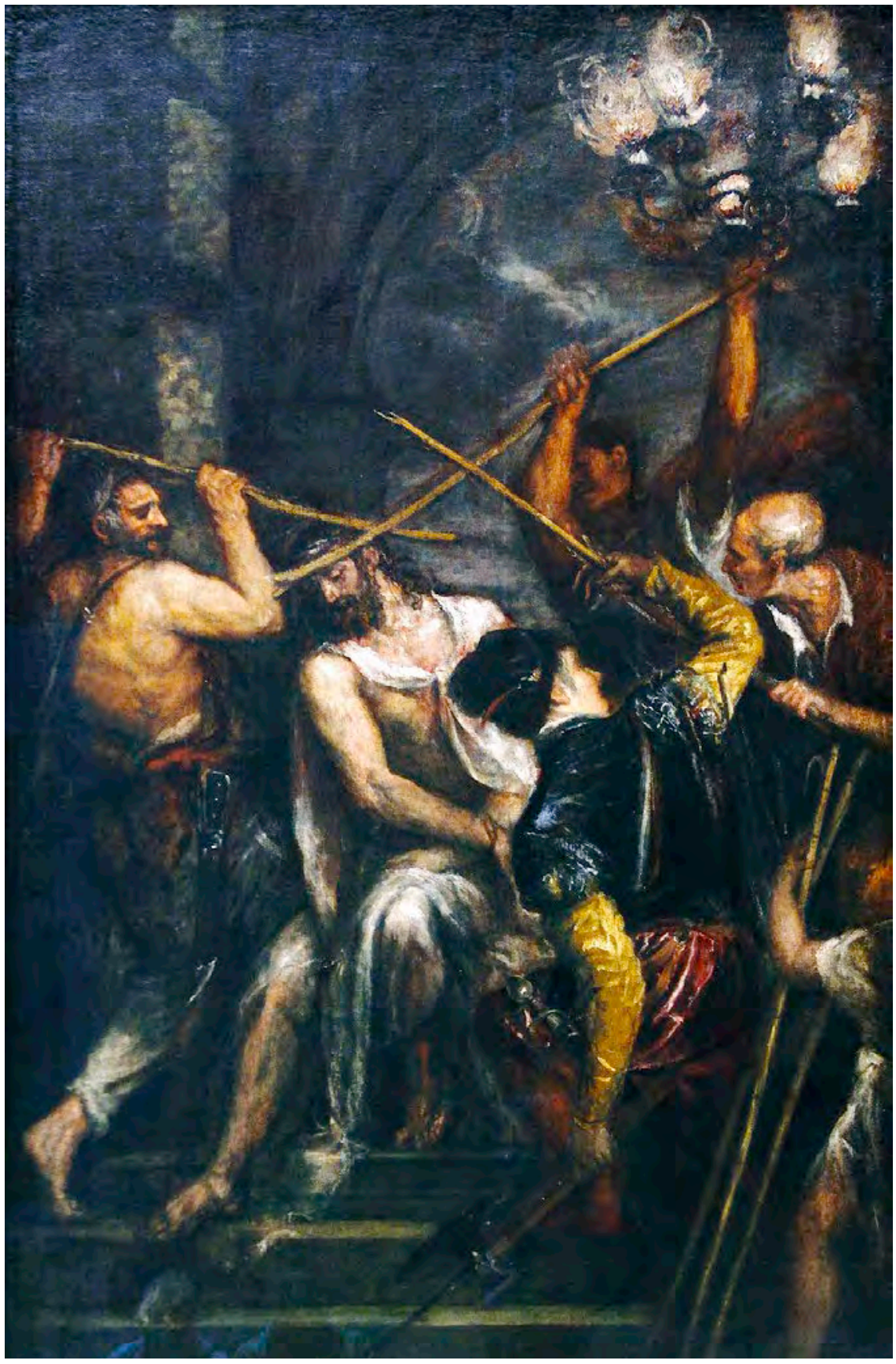

Fig. 18. Tiziano Vecellio, Coronació d'espines, v. 1572-1576, Alte Pinakothek, Munic. 
més o fer distincions com les establertes per Duccio en un cicle excepcional. El blanc impollut es reserva per a algun dels soldats del Judici al políptic de la Pierpont Morgan Library de Nova York, obra del taller dels Bassa, i fins i tot $s^{\prime}$ emprarà en algun dels magistrats que envolten Pilat en obres posteriors, mentre que la tintura blanca pot reaparèixer en les vestidures de Crist en altres escenes, com ara el Camí del Calvari.

Tintoretto, tal com va preveure Giotto en el seu Crist davant Annàs i Caifàs, estudia la fórmula per aconseguir que l'ésser diví superi en jerarquia relativa -i iconogràfica, hi podria afegir - el prefecte romà. Queden molt lluny les fórmules que supeditaven

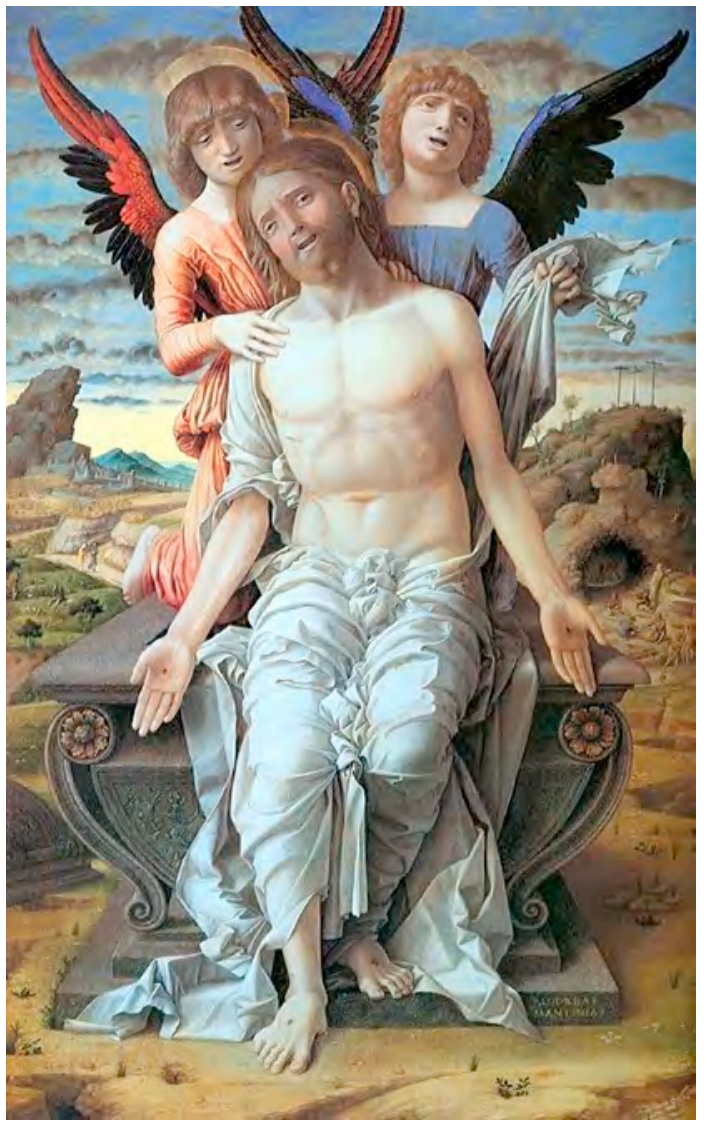

Fig. 19. Andrea Mantegna, Baró de Dolor, Statens Museum for Kunst, Copenhaguen.
Crist a un nivell inferior mentre Pilat gaudia de la perspectiva d'un tron que sobrevolava I'escenari. Ho observem en un brodat del taller de Pieter van Aelst, de cap al 1528, que conec a través de I'Inventario dei beni storici e artistici della diocesi di Trento. ${ }^{48}$ Es tracta d'una manufactura de Brussel.les molt interessant que manté una visió frontal del governant i magnifica el seu posat i la seva situació de poder quan s'enfronta a l'ésser diví, que roman desvalgut i que, per infortuni evident, es veurà obligat a condemnar. En altres passos del Judici la túnica de Crist també pot ser blanca, però es combina amb un mantell més fosc. Per la proximitat geogràfica a Venècia, reproduïm una de les dues taules d'Antonio della Corna (Pàdua, 1469-1491), en què Crist vesteix la túnica alba. La primera representa Crist davant Annàs i fou adquirida el 1981, a les Galeries Römer de Zuric, per La Salle University Art Museum (fig. 21c). ${ }^{49}$ Henry Walters, el 1913, va adquirir a París (Trotti Galleries) una segona taula molt semblant que acull el tema de Crist davant
48 https://www. beweb. chiesacattolica.it/benistorici/ bene/1000011966/Van+ Aelst+P.+\%28ante+1528\% $29 \% 2 \mathrm{C}+$ Arazzo $+\mathrm{di}+\mathrm{Ges} \%$ C3\%B9+Cristo+davanti+ a+Pilato.

49 https://www.christies. com/lotfinder/Lot/antonio-de Ila-corna-active-padua-14691491-christ-6136737-details. aspx. 
50 La tela té unes mides considerables, $260 \times 390 \mathrm{~cm}$, tot i ser la menor de les pintades per als murs de l'Albergo.

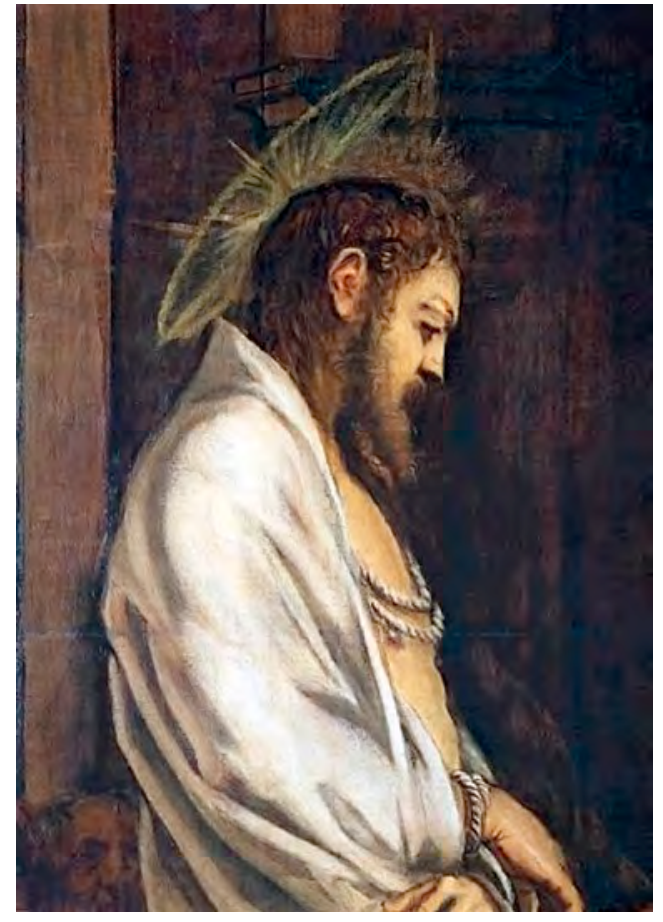

Fig. 20. Jacopo Tintoretto, detall de Crist davant de Pilat, Sala dell'Albergo, v. 1566, Scuola Grande di San Rocco, Venècia. reclama el seu lloc a l'Ecce Homo de Tintoretto (v. 1566) per posar en relleu la seva consciència sobre la falta de culpa de Crist (figs. 22a, 22b i 22c). El paper del romà en aquesta escena és molt important perquè, en fer la declaració que judica el condemnat, es judica a si mateix i judica el seu entorn immediat. El tema es troba al costat esquerre de I'escena del rentament de les mans. Compareix damunt de la porta que dona pas a la Sala dell'Albergo de la Scuola Grande di San Rocco. ${ }^{50}$ Al vell prefecte correspon cridar I'atenció sobre el Crist, ja castigat, a la multitud que ha estat elidida o superposada a l'espectador, que ha de fer-se càrrec del moment amb un punt de vista únic que I'implica. L'Ecce Homo es troba pràcticament nu i exposa el cos sagnant damunt d'un llençol on han quedat les marques de totes les ferides. Un mantell del mateix color avinat, sanguinolent, que tenyeix el vestit de Ponç Pilat, quedarà atrapat sota el cos de Crist, que té encara les mans IIigades i porta el ceptre i la corona d'espines. Fent pendant al romà hi ha un segon personatge poderós que, dret, a la manera del governant, Ilueix una armadura platejada que genera lluentors i reflexos intensos. El militar mira Crist directament, mentre a ell se'I mira I'home que sosté el Ilençol tacat. 

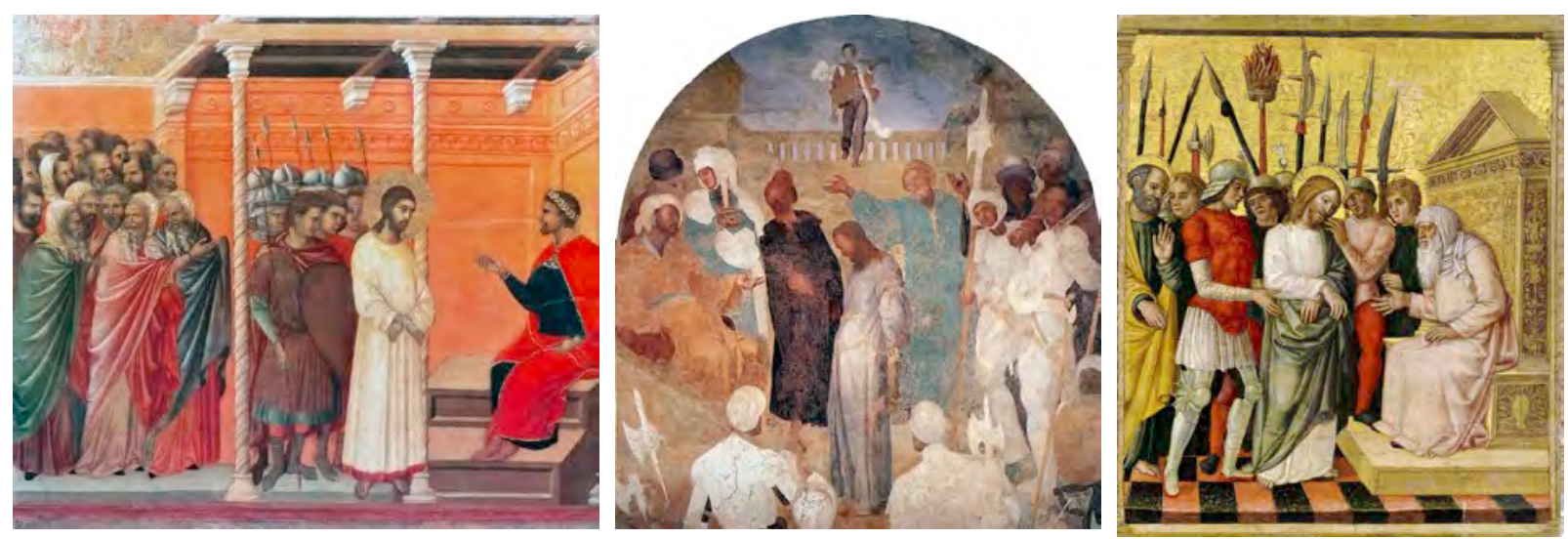

Fig. 21. a, b, c. Duccio, Crist davant Pilat, revers de la Maestà de la catedral de Siena, v. 1308-1311, Museo dell'Opera del Duomo, Siena; Pontormo, Crist davant Pilat, Certosa del Galluzzo, Florència; Antonio della Corna, Crist davant d'Annàs, La Salle University Art Museum.

Tintoretto trava amb mestratge els vincles entre I'autoritat culpable i les seves mans executores. Al darrere de Crist fa aparició un segon home de substrat baix, que aixeca un cortinatge per accedir a aquest espai compromès, amb el seu turbant i un posat d'anar per feina, mentre fa una llambregada a mà dreta. Tot el conjunt de figures ens aboca a resseguir una arriscada perspectiva creada per les escales que cauen sobre la mateixa sala, només frenades pel marc de la porta de gala. La testa de Crist mostra les brillantors «sacralitzadores» pertinents, però cal admetre que manen més uns ulls grossos i extraviats i els regalims vermells de la sang que ha provocat la corona d'espines (fig. 22a). La mirada de Pilat és furtiva i tota la intenció està encastada en el gest i l'actitud, en un pas nerviós endavant que el portarà a obrir els braços també a la recerca de la profunditat (fig. 22b).

És productiu comparar la solució de San Rocco amb la d'una escena del Museu de Arte de São Paulo en què Pilat torna a presentar Crist a la multitud. Es tracta d'una obra anterior de Tintoretto que, cap al 1546-1547, exposava l'innocent dret i pràcticament recolzat en les mateixes figures que I'acompanyen (fig. 23). L'escala hi torna a tenir un paper, però ara distribueix I'escenari i s'integra en una narració més tancada sobre ella mateixa. Als graons s'hi recolzaran algunes figures i un gos adormit, mentre destaca I'home que va ascendint per la banda esquerra. L'escala ha de servir de frontera a la multitud que s'acosta pel mateix costat. Els cavalls i les Ilances, al fons, envolten aquest terme estret que activa a la part alta un cel potent que, com a part del fons del quadre, no recau sobre I'espai de l'espectador.

Més distant, lògicament, és la solució devers el 1515 de Quentin Massys a I'Ecce Homo del Museo del Prado, on Crist, amb la corda lligada al coll 

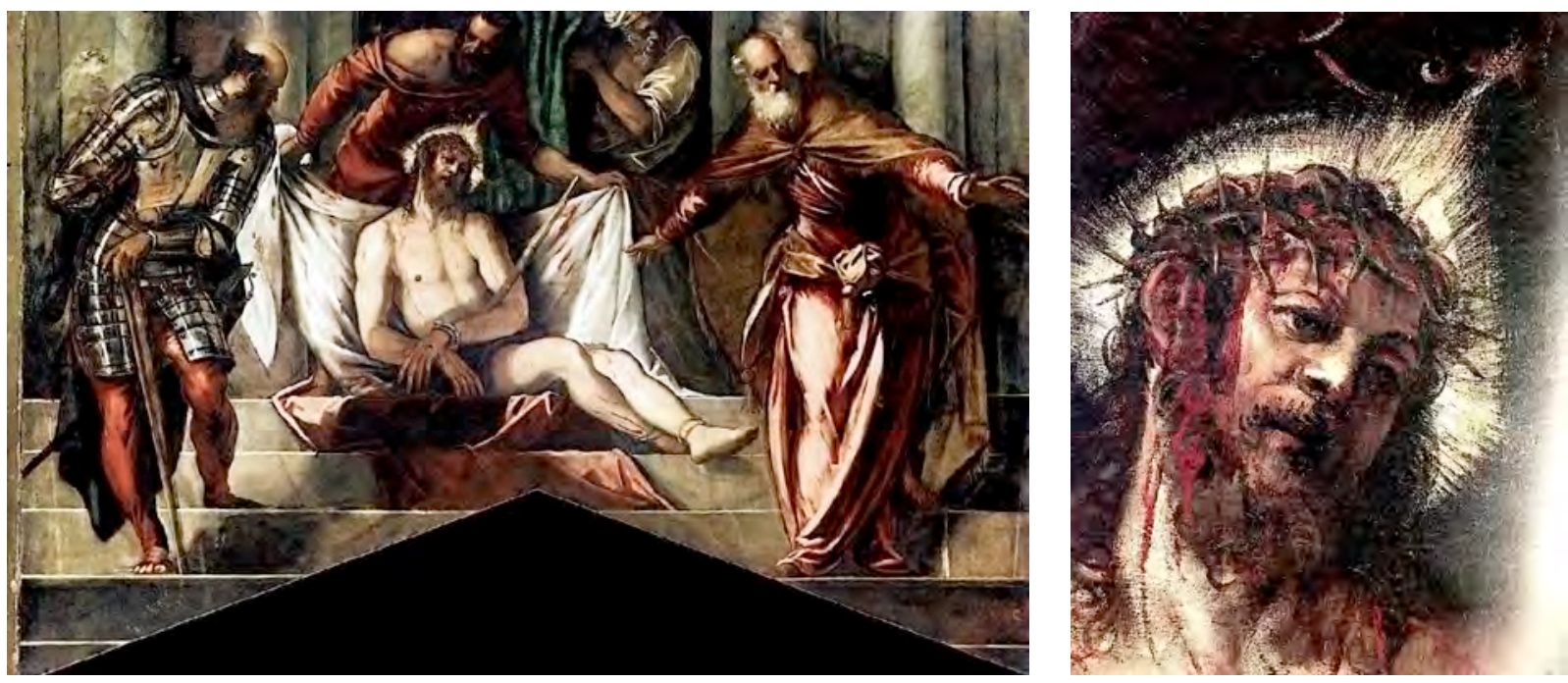

Fig. 22. a, b. Jacopo Tintoretto, episodi de l'Ecce Homo i detall del cap de Crist, Sala dell'Albergo, v. 1566, Scuola Grande di San Rocco, Venècia.

${ }^{51}$ Es coneix una versió de la col-lecció Emil G. Bührle de Zuric, en oli sobre tela, de $149 \times 125$ $\mathrm{cm}$, que ja fou publicada per August L. MAYER, Jacopo Tintoretto, vol. 1, Munic, R. Piper $\&$ Co, 1923, p. 267, n. 1. Per a una fitxa completa de I'obra es pot consultar: https://www. yumpu.com/en/document/ $\mathrm{read} / 20622847 /$ provenienzausstellungen-literaturangabensammlung-egbuhrle. i a les mans, compareix a la balconada al costat d'un Pilat concentrat en si mateix abans d'iniciar el discurs. El grup de botxins embogits que s'aplega a la palestra pot recordar, a banda del foll professional de la part baixa que Ilueix el seu uniforme de bufó, algunes de les solucions bosquianes que prosperen en I'horitzó dels mateixos anys, una mica abans i després de la mort de Hieronymus el 1516.

No es poden oblidar les solucions que proposaria Tiziano, però el seu Ecce Homo del Saint Louis Art Museum, és ja de dates posteriors i, vers el 1570-1576, determina una configuració més suau i intimista en la qual Pilat sembla més proper a Crist, tot i el seu aspecte cortesà, les mans enjoiades i la indumentària fastuosa i fins una mica bufonesca (fig. 24). Tot plegat podrà fer pensar també en un Ecce Homo anterior gravat per Albrecht Dürer vers el 1512.

\section{El camí del Calvari}

Si les dues escenes precedents són originals i sorprenents, el Camí del Calvari de San Rocco no queda pas enrere (fig. 25). ${ }^{51}$ Ràpidament crida I'atenció la disposició del seguici que congrega en el primer terme els dos lladres i els seus acompanyants. Aquest grup segueix la comitiva encapçalada per Crist, que es pot veure enfilat, quan pràcticament arriba ja al capdamunt del promontori. La seva figura em-petitida per la distància torna a ser, gràcies a 

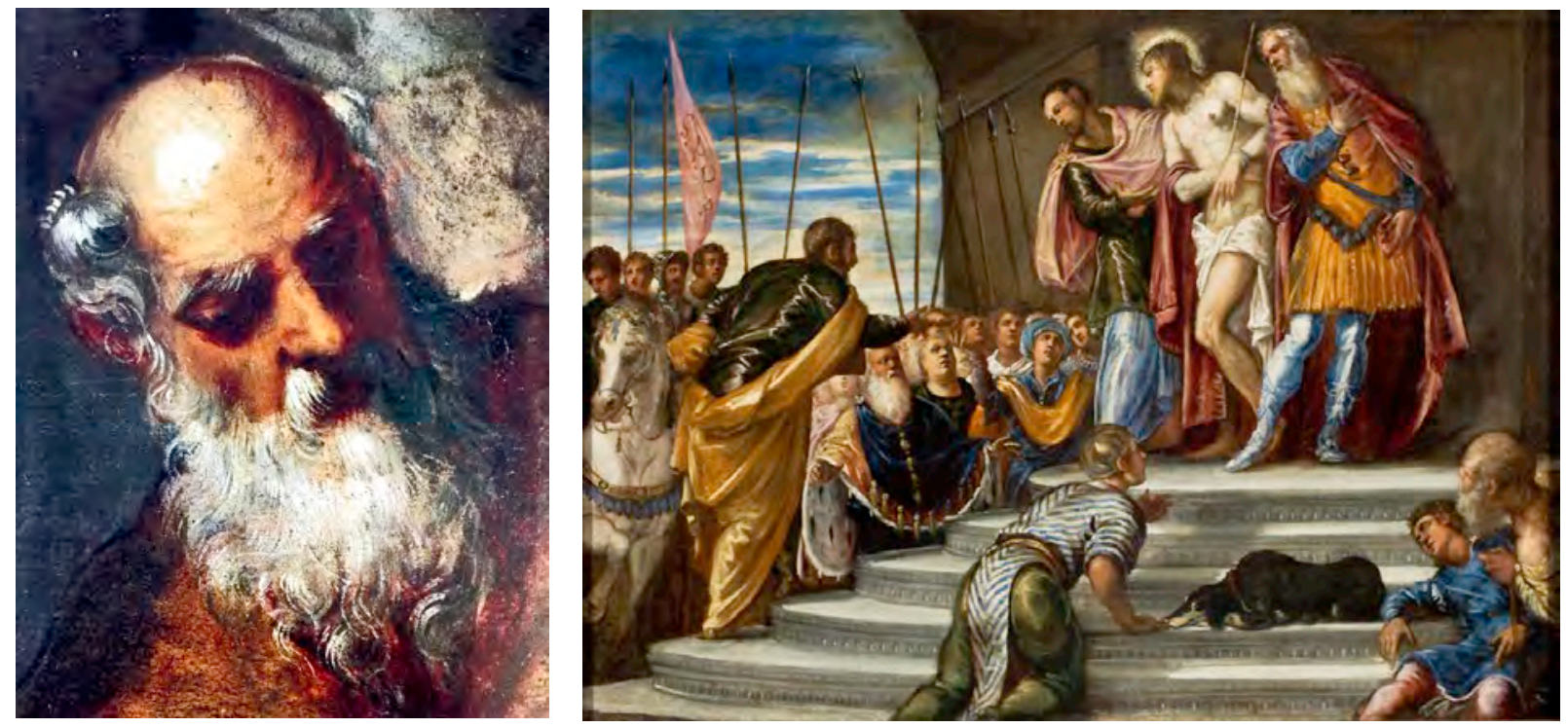

Fig. 22 c, 23. Detall del cap de Pilat, Sala dell'Albergo, v. 1566, Scuola Grande di San Rocco, Venècia. Jacopo Tintoretto, Ecce Homo, v. 1546-1547, Museu de Arte de Sáo Paulo.

les habilitats innegables del pintor, un punt absolutament rellevant de la tela executada vers el 1566-1567. Els lladres, mig nus, es mostren amb les grans i llargues creus encordades en un moment difícil del camí. No porten el pes d'igual manera que Crist, encara que també són ajudats per altres homes que s'agafen als pals verticals dels instruments de martiri. Crist, en canvi, en I'espai elevat, progressa oferint el seu rostre ben bé sota la creu, gairebé com si ja hi hagués estat clavat. Un home de rostre enfosquit gestiona la corda mentre d'altres, a cavall o a peu, el segueixen amb algun estendard rosat (SPQR) que voleia al fons, fent gairebé d'ombrella virtual per a l'espontani que, potser identificable amb Simó Cirineu, també s'acosta

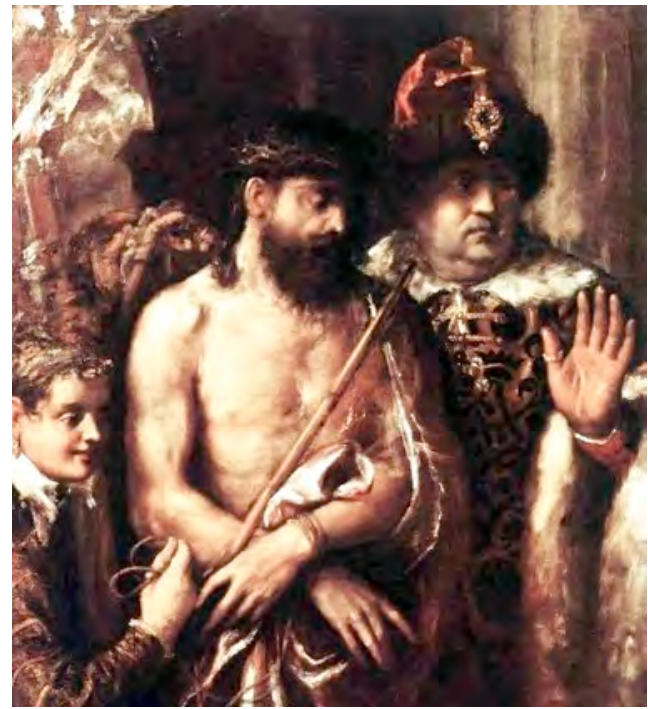

Fig. 24. Tiziano Vecellio, Ecce Homo, v. 1570 -1576, Saint Louis Art Museum. 
52 Rosa Alcoy, El Bosco en dos trípticos del Museo del Prado, en premsa. per aixecar una mica la creu de Crist. Tot és interessant en la instantània aïllada, però aquesta visió des de baix del Crist que camina, amb túnica rosa i mantell blau encordat a la cintura, ha de quedar gravada en la retina sobre un cel que amenaça i congria una aparatosa tempesta.

Per fer un seguiment de models anteriors, podríem recordar les solucions sorgides del taller de Bosch — que tracta el tema en diverses ocasions - que ens poden portar de les seves etapes inicials a la fi de la seva carrera. Encara que I'obra de Bosch mai no deixa de ser original i els seus camins del Calvari renoven molts aspectes que ara no puc entrar a deta$1 / a r,{ }^{52}$ el seu punt de vista queda prou lluny de la perspectiva oberta per Tintoretto perquè es concentra sovint en la visió paral·lela al pla de la imatge i fa recaure la creu, com havia estat habitual, sobre una espatlla de Crist, cosa que descriu una posició clarament asimètrica que no té res a veure amb l'adoptada pel crucificat. La munió de botxins folls del Camí del Calvari, feres en temps de la Passió, també s'allunya del discurs del pintor italià, però ambdós comparteixen una capacitat innegable per obligar l'espectador a repensar les seves propostes i entendre uns missatges que no són tan planers i immediats com es podria esperar.

El mateix Tiziano fa evolucionar el Via Crucis amb un Crist solitari que afronta el Calvari en un quadre del 1560 que, ara al Museo del Prado, revela la nova perspectiva, tot i que ressegueix I'esquema més afermat i conegut (fig. 26). Que I'esquema bàsic sigui conservador no vol dir, és clar, que el seu oli sobre tela $(98 \times 116 \mathrm{~cm})$ ho sigui. Som ben Iluny d'una obra poc innovadora o secundària. És una obra excepcional en tots els sentits, que avala la bellesa d'una imatge en què Cirineu i Crist dialoguen amb les mans i les mirades, I'un per damunt del travesser vertical i I'altre encaixat sota l'encreuament dels dos taulons de fusta. L'òptica pictòrica els apropa. I Tiziano torna a demostrar el seu interès per aquesta relació en un segon Crist portador de la creu del Museo del Prado que, adquirit a Itàlia entre 1637 i 1642 pel marquès de Leganés, passaria a mans de I'arquebisbe de València Isidoro Aliaga i, vers el 1666, a les colleccions reials. El seu plantejament torna a contrastar amb el del Tintoretto, però, malgrat el pes que va poder tenir sobre la seva pintura, el gran Tiziano no es deixa subjugar per esquemes d'altri i genera les seves pròpies i espectaculars plantilles. En canvi, em crida l'atenció la proximitat del Camí del Calvari de la Gemäldegalerie de Berlín creat, ja al segle XVIII, per Giovanni Battista Tiepolo (v. 1738-1740), perquè, sense ser una còpia literal del Camí del Calvari de Tintoretto, és prou clar que en depèn (fig. 27). La figura del Crist sota la creu i els ritmes que configura I'ascensió al Calvari renoven la proposta del pintor del segle XVI sense ocultar completament un deute que imagino ben conegut i 


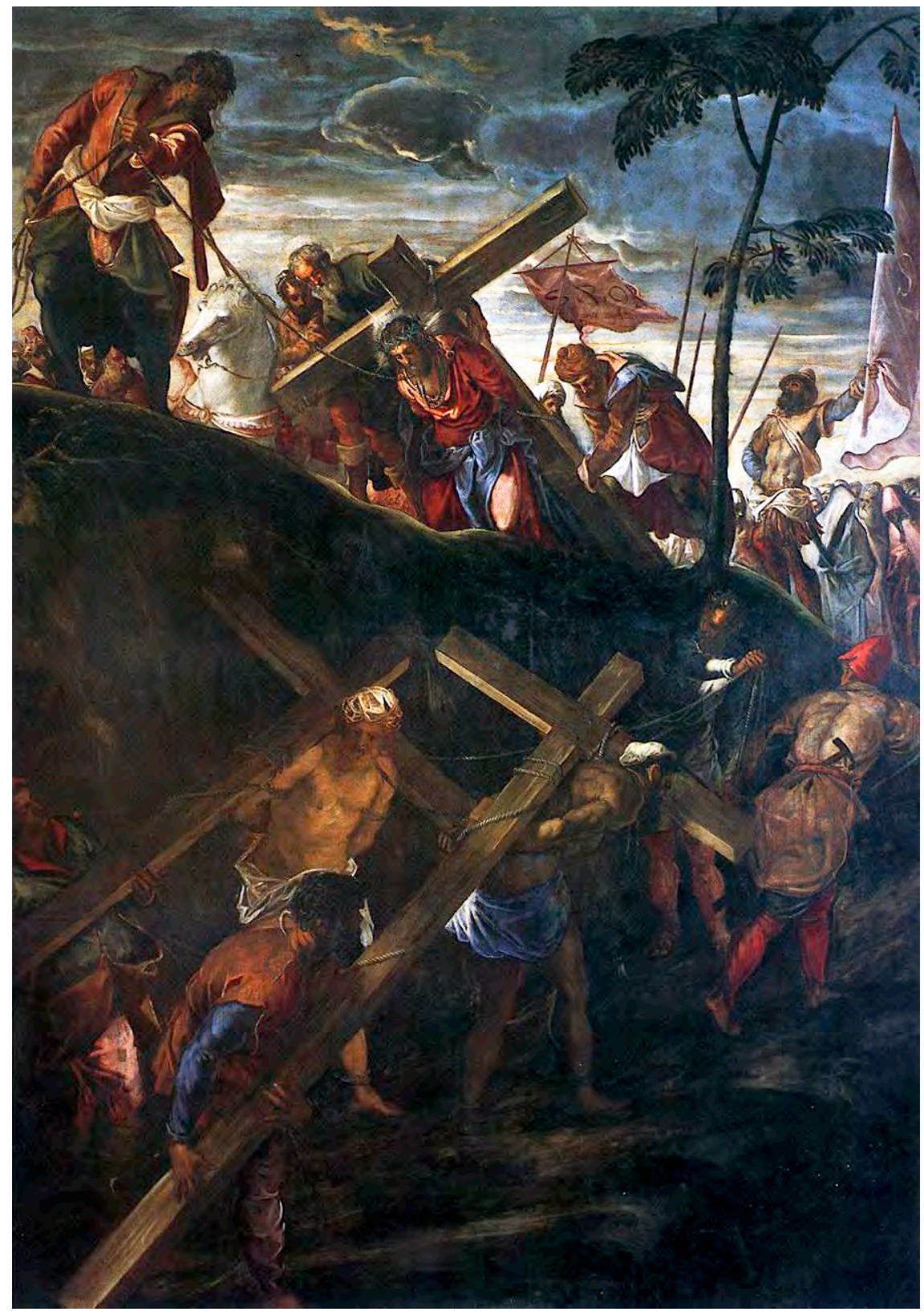

Fig. 25. Jacopo Tintoretto, Camí del Calvari de la Sala dell'Albergo, v. 1566-1567, Scuola Grande di San Rocco, Venècia.

que ens portaria a una altra versió del mateix tema, vinculada també al taller de Tiepolo i que s'exposa a les sales del Museu Nacional d'Art de Catalunya. 
53 És, com en els altres casos, un oli sobre tela, però ara de $536 \times 1224 \mathrm{~cm}$, la més gran de la Scuola di San Rocco, però no la més vasta de les sorgides del taller. El tema remet a les fonts evangèliques: Mc 15, 21 32; Lc 23, 26-43; Jn 19, 17-27, i es pot resseguir fàcilment a Antonio Manno, Tintoretto. La Crocifissione nella Scuola Grande di San Rocco a Venezia, Venècia, Marsilio, 2013; Antonio Manno, «I Vangeli di Tintoretto», P. Rossi i L. PuPPI (eds.), Jacopo Tintoretto nel quarto..., p. 207-211.

54 Les dimensions del conjunt ja devien impressionar Karl M. SwobodA quan escrivia «Die grosse Kreuzigung Tintorettos im Albergo der Scuola di San Rocco», Arte Veneta, núm. xxv, 1971, p. 145-152.

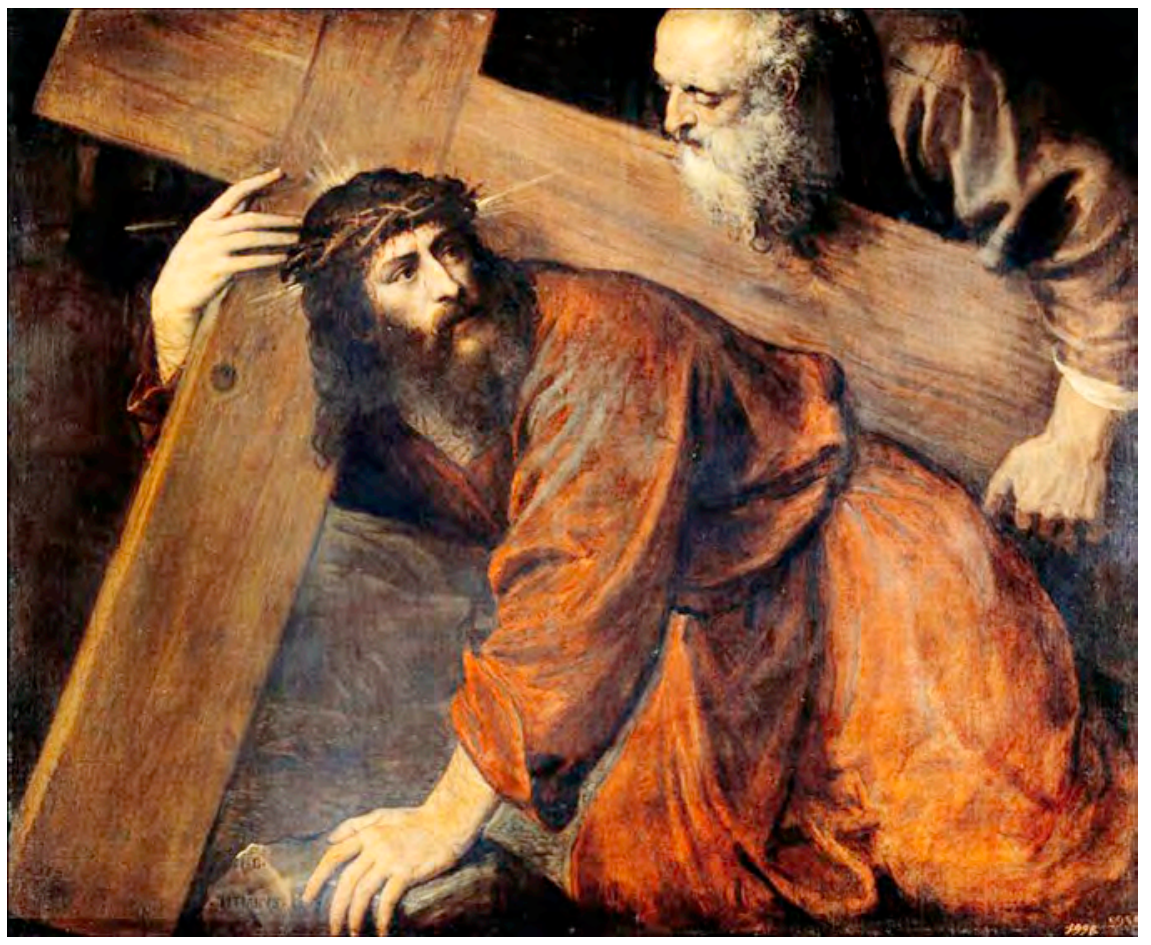

Fig. 26. Tiziano Vecellio, Crist cami del Calvari, 1560, Museo del Prado, Madrid.

\section{El Calvari, any 1565}

Cal fer un gir de cent vuitanta graus per encarar la composició centrada en el Calvari, una pintura d'excepcionals dimensions que omple el mur del fons de la sala, ${ }^{53}$ per damunt del ric arrambador de fusta que, trenat d'escultures, ressegueix el perímetre de l'estança de I'Albergo i genera un banc corregut en les zones escaients. Al davant de la immensa Crucifixió de Crist hi ha espai per a la taula destinada a I'òrgan de govern de la Scuola, ja que la sala era lloc de reunions i de presa de decisions, un ús que es podria considerar habitual o normatiu en espais de govern o de caràcter judicial i que aquí s'oblida totalment com a convenció establerta per la mateixa magnitud assignada al tema. Els finestrals que s'obren als trams curts de l'aula il-luminen I'espai i, amb una decoració blanquinosa, similar a la de l'accés, carreguen les columnes i els vistosos arquitraus amb frontispicis triangulars (fig. 28). L'epígraf situat a la banda inferior esquerra, integrat en la pintura, no deixa cap dubte sobre la cronologia i I'autoria: M.D.LXV | TEMPORE. MAGNIFICI | DOMINI HIERONYMI | ROTAE, ET COLLEGARUM | IACOBUS TINCTOREC | TUS FACEBAT. ${ }^{54}$ 


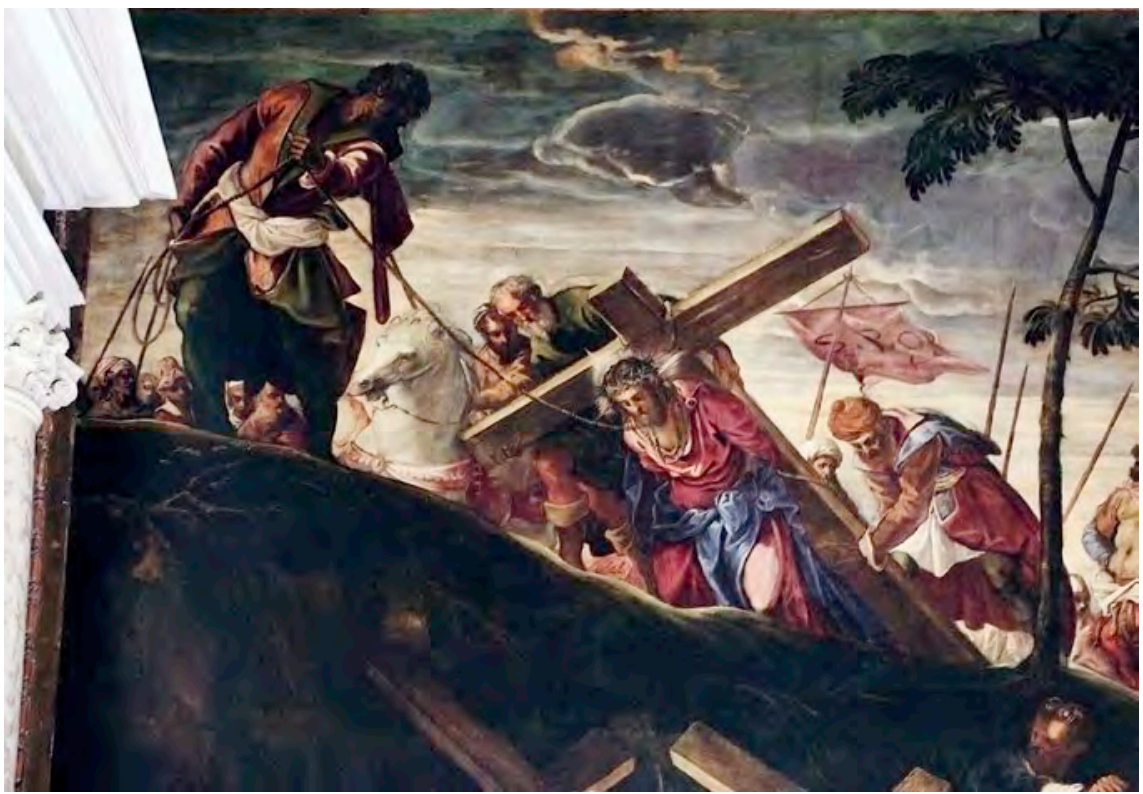

Fig. 27a. Jacopo Tintoretto, detall del Camí del Calvari, Sala dell'Albergo, Scuola di San Rocco, Venècia.

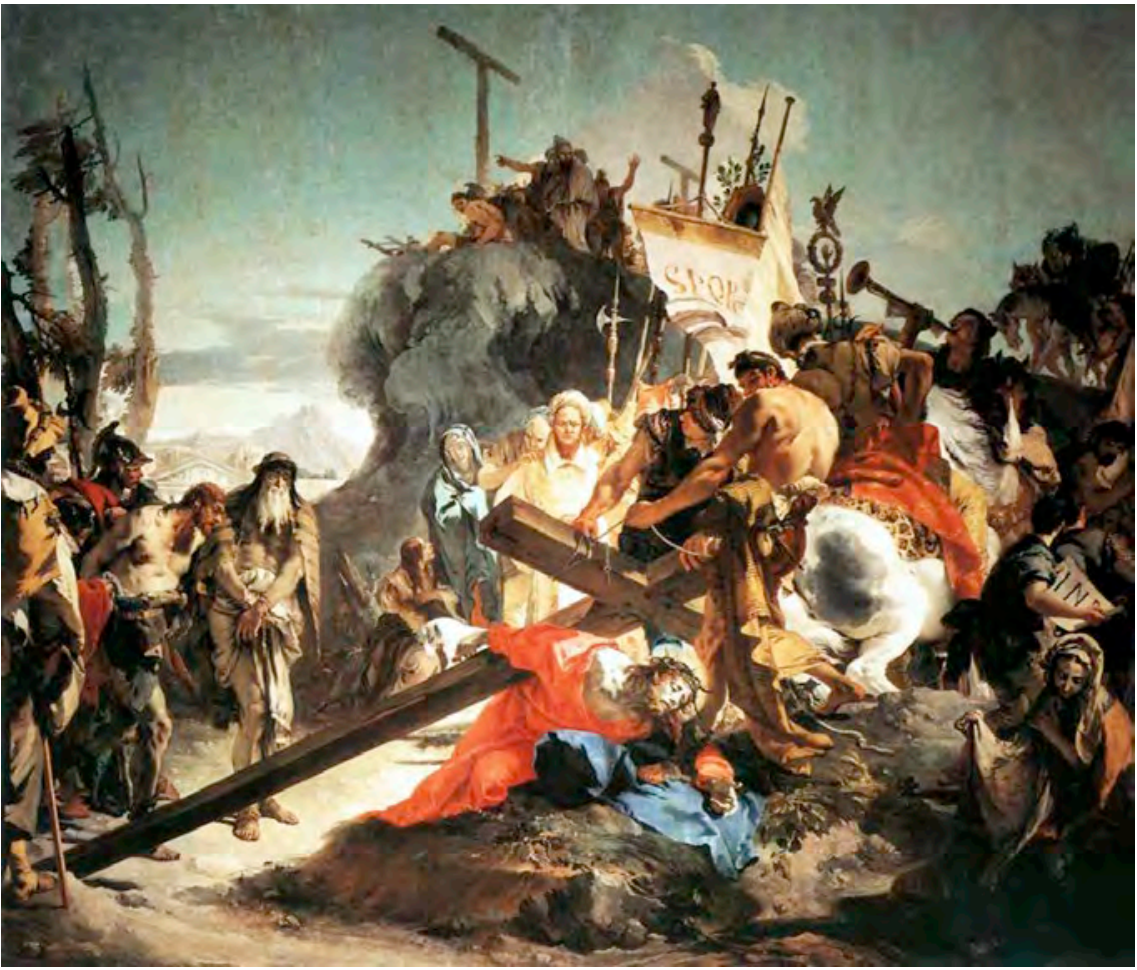

Fig. 27b. Giovanni Battista Tiepolo, Camí del Calvari, v. 1738-1740, Gemäldegalerie de Berlín. 
55 No m'entretinc amb les qüestions relatives a les funcions de la Scuola, ressenyades en diversos treballs citats i al.ludides també, i aquesta sala en concret, a A. Manno, Tintoretto. La Crocifissione..., p. 6-8, que la considera el cor de la seva Caritat, alhora que relaciona sant Roc, imitador de Crist, amb el rol i la influència dels franciscans instal.lats a la zona veïna a la Scuola.

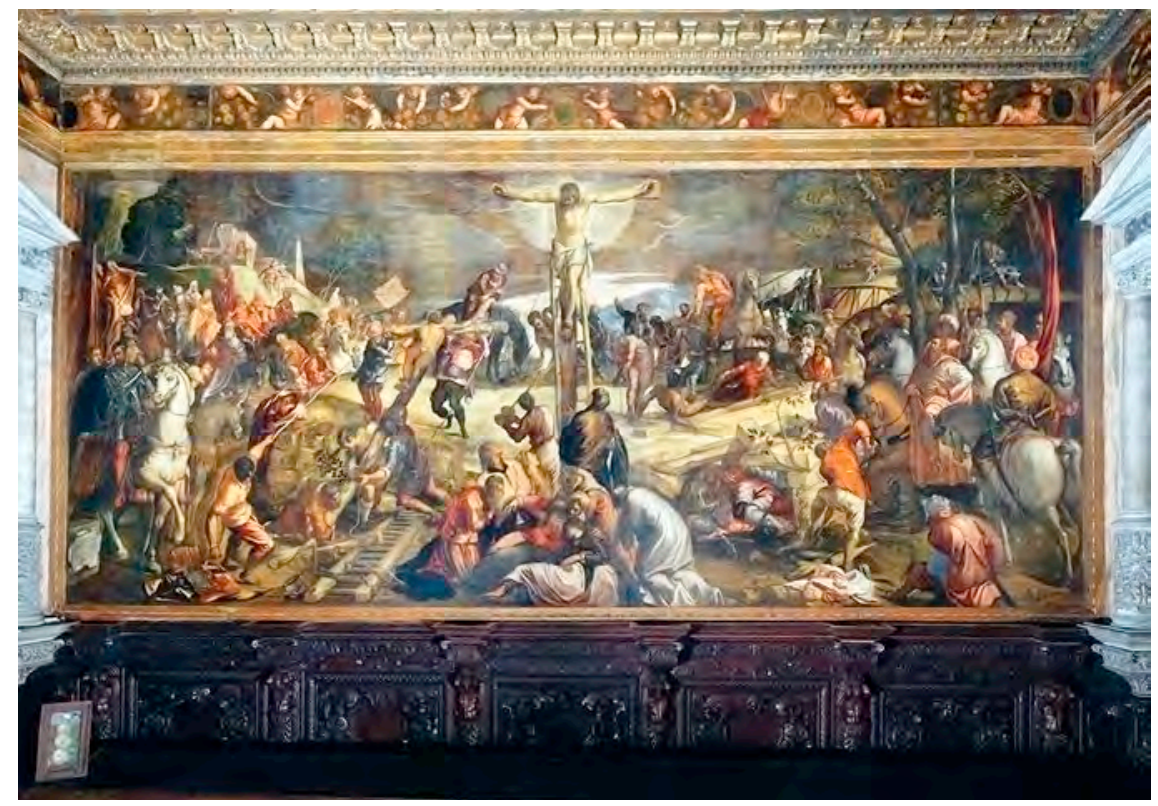

Fig. 28. Jacopo Tintoretto, Crucifixió de Crist, 1565, Sala dell'Albergo, Scuola Grande di San Rocco, Venècia.

La pintura crea efectes innovadors que caldrà remarcar pas a pas i que des de l'àmbit iconogràfic sostenen les noves propostes formals que interessen al pintor. ${ }^{55}$ En termes generals, no s'estalvia algunes paradoxes quan fa confluir el cap de Crist amb el límit horitzontal superior de la pintura i, al mateix temps, separa la creu del primer terme, on gairebé s'apilonen les Maries i altres figures properes al Mestre, com ara sant Joan i Josep d'Arimatea. La Magdalena podria ser la dona ajupida i de cabells rossos ben visibles que mira commoguda la creu, encara que li pren la davantera una dona dreta que mira amunt astorada. L'instant sembla precedir el moment d'abraçar la creu amb el gest que s'hauria pogut veure tantíssimes vegades tenint com a protagonista la santa i antiga pecadora. Observem que aquests registres icònics permeten que el Crist sigui una figura emplaçada a la part alta, sobre el primer terme, per més que li correspongui el segon si ha d'alliberar l'espai que pertoca als seus fidels a la zona inferior. Maria Magdalena no pot abraçar la creu, ni tampoc cap altra dona arriba a fer-ho, mirem d'aclarir-ho, perquè una escala de mà encara roman recolzada al pal vertical, emprada per una parella d'homes que semblen traginar amb l'esponja i el vinagre, en un moment encara previ a la mort del sentenciat. Aquest peu de la creu sobresurt per ell mateix, igual que el Crist robust i amb sever potencial victoriós que ha estat descrit com a eix central indiscutible de tota la composició, àrbitre d’una escenografia especialment dilatada i complexa, 
ben a la par dels dotze metres de pintura que s'estenen de punta a punta d'una franja de més de cinc metres d'ample. ${ }^{56}$ Tintoretto no descuida cap detall i aconsegueix que la seva sigui una projecció suculenta en tots els racons i raconets d'una pintura tan extensa. El perill dels desequilibris visuals i les inintel/ligibilitats discursives creix amb les mides, però el venecià domina amb una solidesa envejable tots els recursos que fan que els encaixos i les sutures, tot i ser innovadors i cridaners, siguin ben poc perceptibles.

L'ús que va fer el pintor dels textos no és l'objectiu d'aquest breu estudi. Les seves dimensions impedeixen entrar en el debat que emmarca les fonts i la relació entre els textos i les imatges. És clar que aquestes ineludibles referències han estat resseguides ja en diferents treballs que han insistit en la importància de les fonts bíbliques, però també les apòcrifes, les litúrgiques i les teatrals, sense descartar els comentaris dels pares de I'Església i els inabastables textos d'altres religiosos i ordes diversos. Val la pena, amb tot, remarcar la importància assolida per les Meditationes vitæ Christi i una cultura religiosa específica en la qual s'aprecia sovint el vincle amb contextos franciscans. ${ }^{57}$

Per començar, cal dir que la situació de les dones, sant Joan — que també aixeca el cap- i el que podria ser un dels cristians, és factible que Josep d'Arimatea, és singular i es correspondria, més que no pas amb un Calvari, amb la composició d'un Davallament de la creu o d'una Pietat complexa. En el marc de la Crucifixió, en sentit estricte, no havia estat tradició ocupar l'espai frontal anterior a la creu amb l'escena del desmai de la Mare i els seus acompanyants (fig. 29). Es tracta, per tant, d'una Ilicència que implica desplaçar tot el grup, que acostumava a ocupar l'espai situat a la dreta de Crist, a un centre que permetrà al pintor diversos exercicis més d'una fondària reflexiva que no pas minúscula. Per tant, no és secundari que hagi optat per situar els bons, inqüestionablement benaurats, en el lloc que Ilargament havia ocupat el crani d'Adam i sovint també alguns dels seus ossos. En algun cas excepcional, aquest espai del peu de la creu havia permès al·ludir a la resurrecció dels morts i al pecat original que introduïa la mort enfrontada a la Creu salvadora. ${ }^{58}$ L'espai esquerre de la imatge, però a la dreta del crucificat, va ser ocupat reiteradament pels seus seguidors. No cal acumular-ne exemples, encara que valgui la pena constatar que fins i tot ocupen aquest espai personatges santificats que no hi eren en el seu moment, com pot exemplificar sant Francesc en un dels Calvaris que Cimabue va pintar a la basílica superior d'Assís o alguns donants que també envaeixen la base de la creu en temps medievals. ${ }^{59}$ També és clar I'emplaçament en I'escena que va desenvolupar Pietro Lorenzetti en el marc inferior del mateix temple, on Maria i els seus envolten la creu del Iladre bo (fig. 30). La qüestió dels Calvaris en versió exten-
56 Manno fa notar la mancança de la ferida al costat de Crist, fet rar que s'explica apuntant a una restauració maldestra, atès que el gravat a partir de Carracci revelaria, tot i que molt discretament, la presència del detall: $A$. MAnNo, Tintoretto. La Crocifissione..., p. 26. Vegeu també les seves apreciacions sobre la possible identificació del soldat romà Longí ( Longinus), que no deixen de contradir en part el que es mostra als gravats.

57 Ester Brunet, La Bibbia secondo Tintoretto. Guida biblica e teologica dei dipinti di Jacopo Tintoretto nella Scuola Grande di S. Rocco, Venècia, Marcianum, 2012.

58 El foli 60 del Sacramentari de Fulda, v. 975, manuscrit theol. 231, Gottingen Universitats Bibl., així ho planteja. Vegeu una visió més sintètica al Sacramentari de Sant Cugat, ACA, ms. 47, que ho redueix tot a la figura d'un Adam redimit, que mira amunt i estén els braços.

59 Rosa Alcoy, Anticipaciones del Paraíso. El donante y la migración del sentido en el arte del occidente medieval, Vitoria-Gasteiz, Sans Soleil, 2017. 
60 Rosa Alcoy, «Ideas para lo ordinario y para lo extraordinario en las representaciones góticas de la Pasión de Cristo, prospecciones en Cataluña y en otros contextos del 1300», Codex Aquilarensis, núm. 27,2011, p. 155-190. sa obliga també a passar pel Cappellone degli Spagnoli de Santa Maria Novella, a Florència, i retrobar els murals d'Andrea Bonaiuti (13191377), on les coses, ja als anys seixanta del segle XIV, tampoc no han canviat radicalment. La tensió entre dreta i esquerra es manté en I'obra d'Altichiero a Pàdua, encara que ja s'hi podrien introduir alguns matisos interessants que afecten I'emplaçament de la Magdalena abraçada a la creu. ${ }^{60}$ Arribats quasi a mitjan segle $x \mathrm{~V}$, el Beato Angelico respectarà la tradició en el seu Calvari de la Sala Capitular del convent de San Marco de Florència (v. 1440-1442), de la mateixa manera que ho farà Andrea Mantegna en el seu més famós i excepcional Calvari per a San Zeno de Verona (1456), on la plataforma natural no deixa de ser un referent per a la que valorem com a creació de Tintoretto.

Aquest 0 algun altre recorregut que es podria fer per l'art medieval i del Renaixement ajuda a corroborar la dimensió excepcional de la tria realitzada, la qual permetrà a Tintoretto alliberar la banda de l'esquerra, la més immediata a la creu, per ubicar-hi una Ilarga escala dipositada a terra que ha de dimensionar la distància sobresortint que separa virtual-

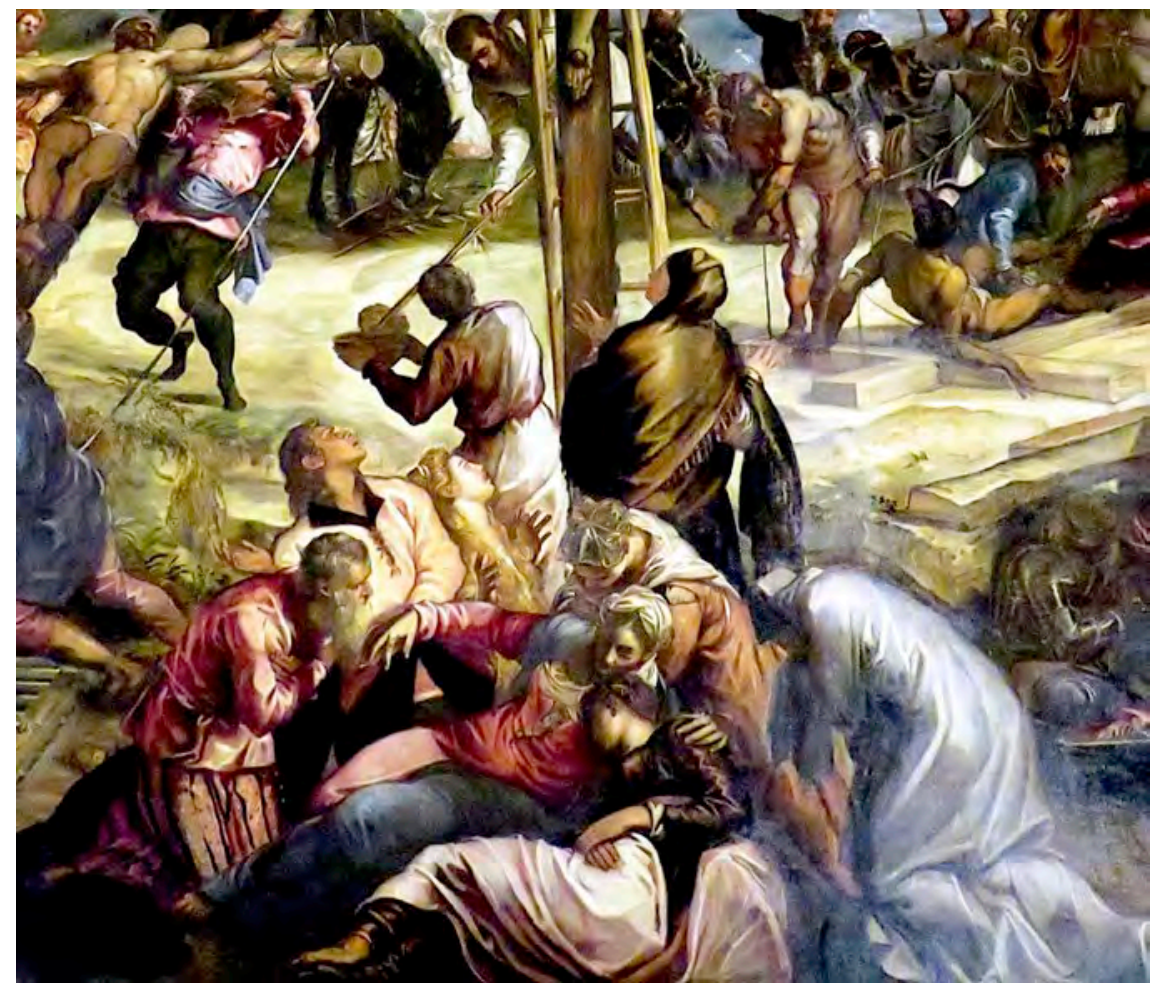

Fig. 29. Jacopo Tintoretto, grup de les Maries, Crucifixió de Crist, 1565, Sala dell'Albergo, Scuola Grande di San Rocco, Venècia. 
ment el primer pla de la pintura de la creu (fig. 31). A terra s'amunteguen tota mena d'eines, un petit inventari d'aparells posats al servei de fusters o manyans. Sobre aquest eix quasi perpendicular que determinen els muntants de I'escala, sustentats pels travessers, es crea la diagonal mitigada que abasta diferents plans i que genera la creu de Dimes, el bon lladre, un instrument de martiri que intenten aixecar amb esforç i les cordes pertinents mitja dotzena d'homes. El delinqüent penedit tomba el cap vers un Crist ben predisposat a veure'l i procurar-li la redempció, malgrat que els plans on s'haurien de creuar les respectives mirades no puguin guardar la deguda correspondència.

El centurió de Cafarnaüm que assenyala la creu al seu acompanyant és identificat amb el genet sobre vistosa muntura blanca. Manno hi veurà també el retrat d'un possible alt oficial de la República veneciana. Si aquesta opció és real i va prosperar també en altres casos que afectarien

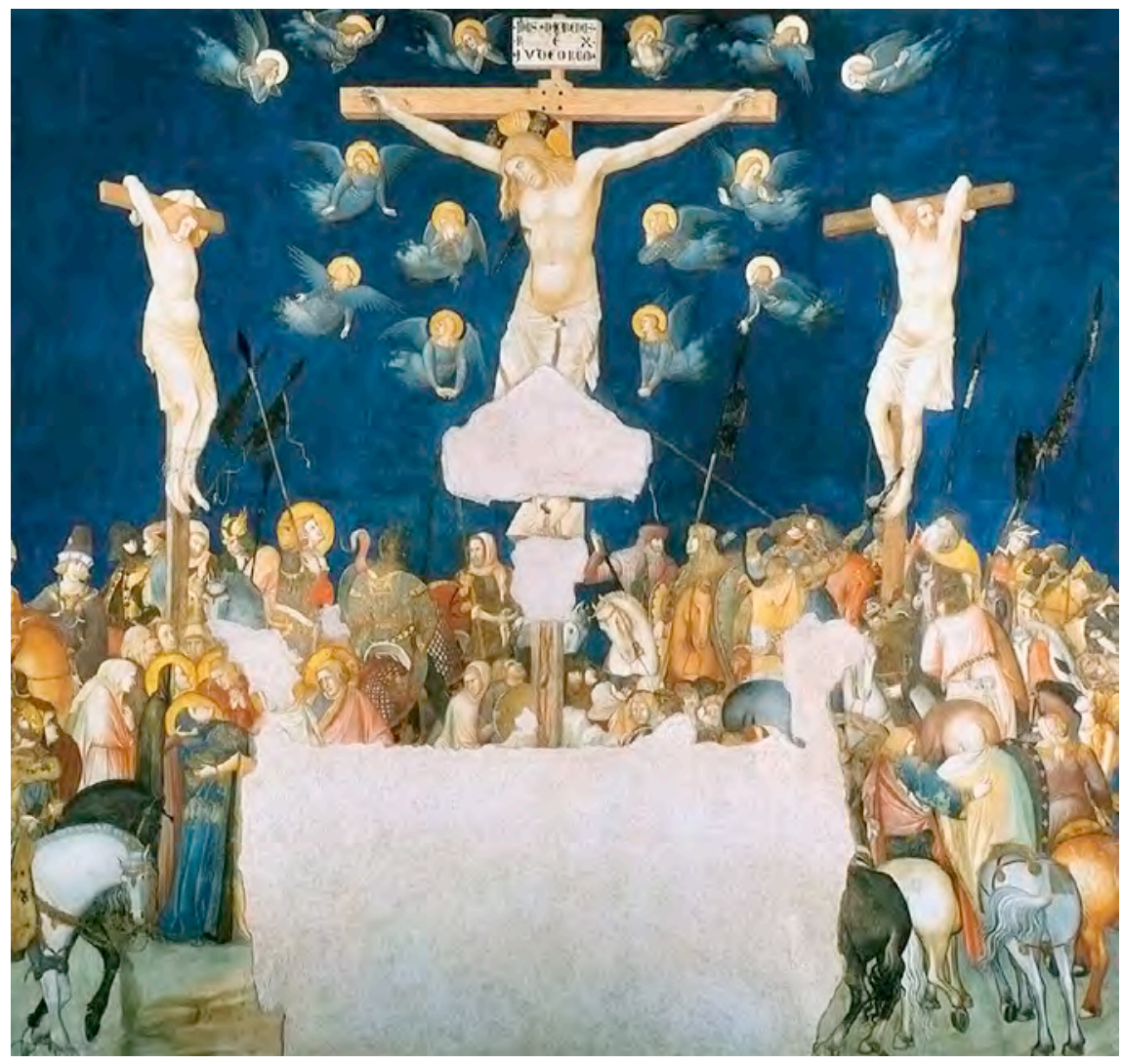

Fig. 30. Pietro Lorenzetti, Crucifixió de Crist, transsepte de la basílica inferior de Sant Francesc d'Assís. 
61 A. Manno, Tintoretto. La Crocifissione..., p. 22. així mateix el Camí del Calvari, en particular els subjectes misericordiosos que ajuden els condemnats, el pintor seguiria un joc de substitucions que, tàcit o explícit en cercles concrets, havia estat a l'ordre del dia en temes com ara I'Epifania, el Plany sobre el cos de Crist mort o el Davallament. A la figura del centurió s'hi oposarien els genets de la banda dreta. Crida I'atenció el reconegut com un otomà que ens dona l'esquena i que es vincula a altres infidels turcs que poblen l'escenari i que podien preocupar com a amenaça real a la ciutat adriàtica. Ben plantat i donant la cara s'imposa un segon cavaller d'identitat més discutida. Per a Manno ha de ser Caifàs, ricament vestit a l'estil oriental, un personatge que actuaria com el representant més destacat del món jueu, directament implicat en la condemna de Crist. ${ }^{61}$ Altres propostes apunten a Ponç Pilat, però per més d'una raó no em sembla que aquesta identificació li escaigui. La primera tindria un caire immediat, ja que la figura dista molt del personatge que actua a I'escena del Rentament de mans o a l'Ecce Homo de la sala. Es fa difícil

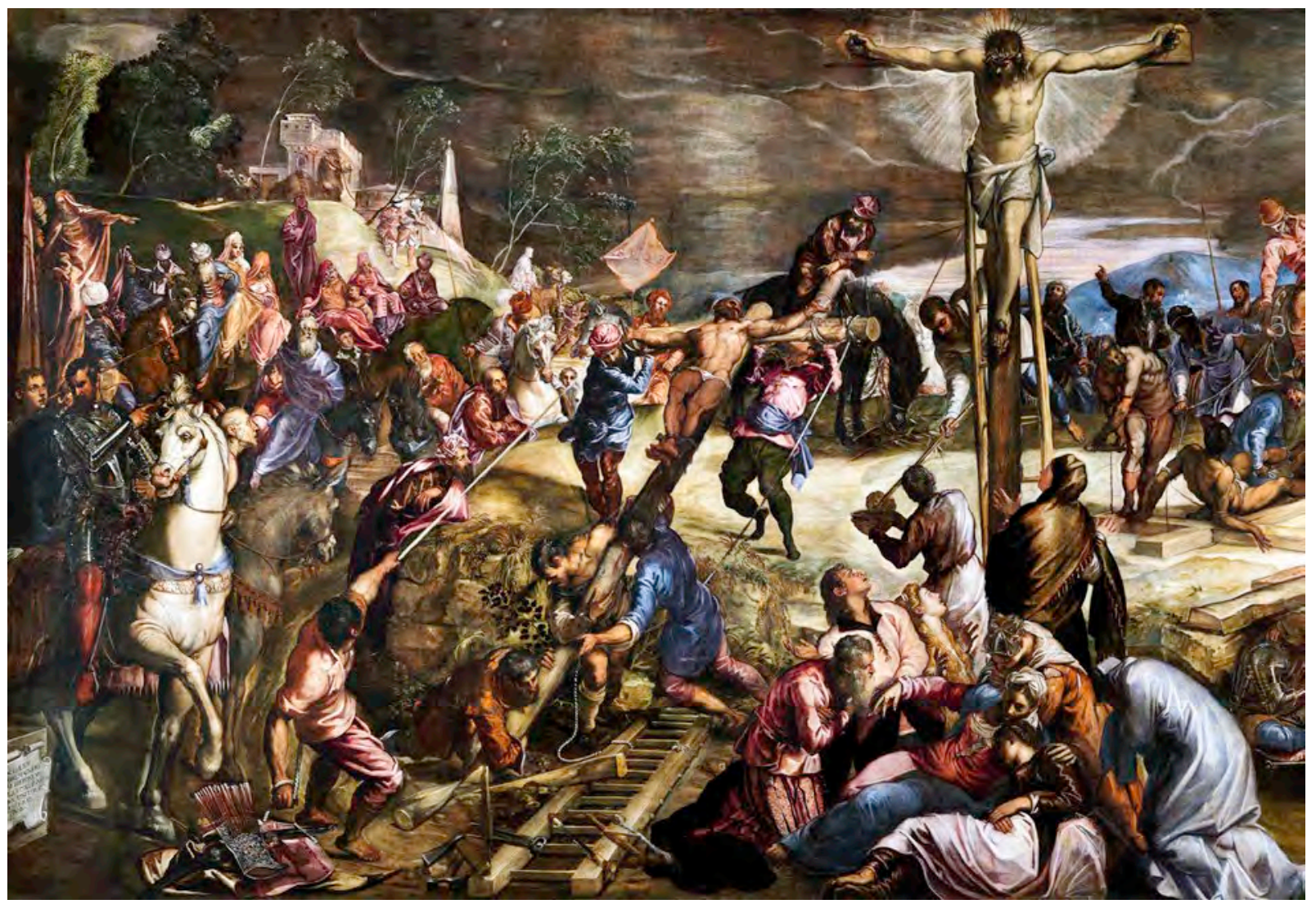

Fig. 31. Jacopo Tintoretto, banda esquerra de la Crucifixió de Crist, 1565, Sala dell'Albergo, Scuola Grande di San Rocco, Venècia. 
creure que el prefecte hagi recuperat la cabellera i s'hagi engreixat en tan poc temps. La segona raó té a veure amb el posat fanfarró del cavaller, que no és coherent amb la voluntat d'escapolir-se, o d'implicar-se el mínim, de Ponç Pilat, algú que considera una injustícia la condemna, opinió expressada reiteradament i sense embuts en la presentació de Crist a la multitud: «Ara us el trauré aquí fora, perquè sapigueu que no li trobo res per poderlo inculpar». I també en la resposta als que demanaven la crucifixió: «Emporteu-vos-el vosaltres mateixos i crucifiqueu-lo, que jo no li trobo res per poder-lo inculpar». Per consegüent, una declaració en tota regla de la innocència del reu que contradiu el posat del genet clarament afecte als defensors de l'ajusticiament. ${ }^{62}$

Resseguint vers el fons aquesta banda de la tela, contrària a la del grup del centurió, veurem el mal lladre, que és clavat a una creu completament aplacada encara a terra. ${ }^{63}$ No es tria només la mà esquerra de Crist, sinó que també es posterga l'acció a un pla més secundari i llunyà i, d'aquesta manera, també s'allibera l'altre costat de l'escenari, on es reprodueixen els mals exemples. Res no farà evident un eix de simetria al costat del qual es fixen dues creus més. Crist trona sol sobre la creu alta que el distancia de tot allò que I'envolta. No ha de competir amb cap Iladre, ja sigui bo o dolent. La seva és una acció única i exclusiva que destaca la seva posició en el vèrtex que configuren les dues diagonals nascudes d'un mateix punt. El nus, esborrat o encobert pel grup de les dones i sant Joan, persisteix gràcies a l'encreuament a dreta i esquerra d'aquests dos eixos grans i potents. L'espai generat a la dreta de la imatge serà ocupat per un esvoranc construït en la roca i que fa possible ubicar, en un lloc força insòlit, la juguesca dels soldats que voldrien posseir la túnica de Crist (fig. 32). Se'ls veu amb els daus entre mans, clandestins i amagats de les mirades, Iluny de la vistositat que adquireixen en el Calvari de Giotto, a I'Arena, on un ganivet sembla donar a entendre que les coses aniran de mal borràs. El tema del joc té un valor més estructurat, i supervisat pels sacerdots, en mans d'Altichiero i altres mestres del Trecento i el Quattrocento que treuen suc a l'anècdota i que fan pensar en el caire misteriós que Tintoretto afegeix a l'apunt, que és reflexió sobre un atzar deshonrós que no satisfarà a ningú. 64

Tot té les seves conseqüències i els cavalls i la gentada acaben circumdant amb mil anècdotes i posats un decorat que tendeix a definir un escenari alt i un de més baix. Són dos nivells segregats que fan funcions importants en I'obra. El primer és ensotat, a manera de prosceni, i el configura la terra fosca. El segon és pròpiament l'escenari i és delimitat per la roca 0 pedra més fortament il.luminada que, com he assenyalat, construeix les dues diagonals o radis d'una roda escènica incompleta. Aquest espai elevat
62 Opta per identificar Pilat E. BRUNeT, La Bibbia secondo Tintoretto..., p. 27-29.

63 Totes aquestes qüestions troben els seus precedents, però en aquests casos el protagonista del clavament a la creu era Crist, i no pas els Iladres. Crist puja a la creu en una miniatura de Pacino di Bonaguida devers el 1320, i el mateix tema va ser tractat per Giovanni Baronzio, v. 1325 (Gallerie dell'Accademia). El clavament es pot veure al Saltiri anglocatalà de París (París, BnF, ms. lat. 8846) i als murals de Valnerina, però cap d'aquestes fórmules no s'inventa al segle XIV. Es pot observar ja en obres italianes anteriors, com ara algunes creus pintades al segle XIII.

${ }^{64}$ A. Manno, Tintoretto. La Crocifissione..., p.18, relaciona I'obertura on s'amaguen aquests soldats amb la cisterna que, ajustada a la plataforma pètria, ja havien pintat Mantegna o els Bellini als seus Calvaris. 
65 Tant Miquel Àngel com Tintoretto resolen per aquesta via algunes de les seves principals propostes, dissonants 0 matisades en altres obres com ara el Calvari del Museo Civico de Pàdua, algunes obres dels Bassano i encara d'altres del mateix Tintoretto. Sobre la restauració de la Crucifixió de Pàdua, vegeu S. ABram (ed.), La crocifissione di Tintoretto. L'intervento sul dipinto dei Musei Civici di Padova, Torí, Editris 2000, 2013. reproduiria en part, sobre el terreny, la forma astral lluminosa que permet donar ales al Crist clavat sobre una altíssima creu (figs. 31 i 33a). És interessant la disposició dels braços, que no pengen avall, com passa en la pintura del gòtic septentrional, en creus esculpides, i es comença a albirar també en l'art de Giotto. Els braços es mantenen rectes com en un exercici gimnàstic molt conegut, tot configurant la tau que reprodueix el bastiment de fusta. La situació no és nova, ja que la pintura bizantina i italobizantina medieval se n'havia servit amb escreix, i incloc Cimabue en el recompte. Allò que canvia és I'anatomia dels braços, que deixen de ser formes retallades per un dibuix fluid que dissenya els plans pe $r$ entomar la força dels volums, que marquen els músculs i les articulacions com a fornit embolcall dels ossos. Hi ha un apropament a Miquel Àngel que cal acceptar i que podem observar a partir d'un esplèndid dibuix del British Museum, que es completaria amb altres troballes recents (figs. 33 a i 33 b) ${ }^{65}$ Com acabem de veure, la roca de la Sala dell'Albergo té un cau que ha estat ocupat pels soldats, que improvisen així un petit amagatall on jugar-se la túnica, ben poc sensibles al que està passant. D'alguna manera, arriben a prefigurar els soldats que vigilaran el sepulcre, insensibles i incapaços d'evitar la resurrecció de Crist. Ara són davant d'un Crist que s'alça poderós davant la mort i es presenta, així com era ordenat, per ser el jutge genuí de la humanitat sencera. Encara al Calvari, uns treballen durament mentre d'altres són tafaners coneguts o comentaristes destacats, entre els quals es colarà algun

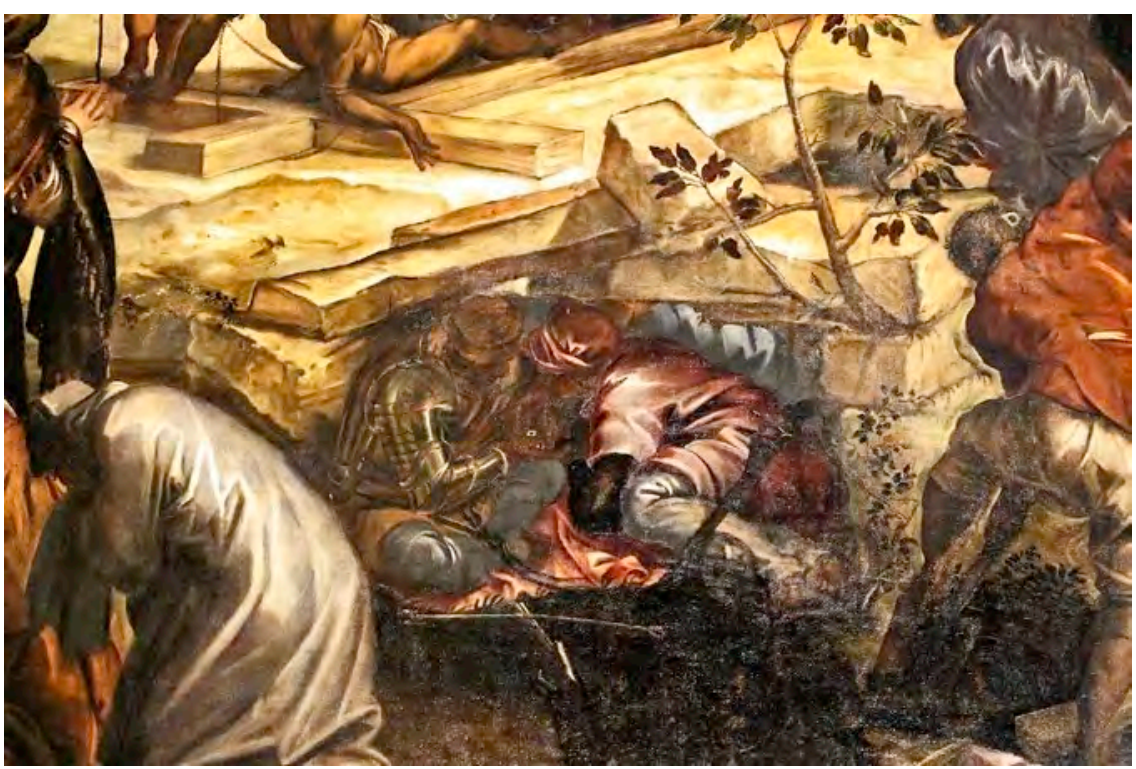

Fig. 32. Jacopo Tintoretto, detall de la Crucifixió de Crist, 1565, Sala dell'Albergo, Scuola Grande di San Rocco, Venècia. 

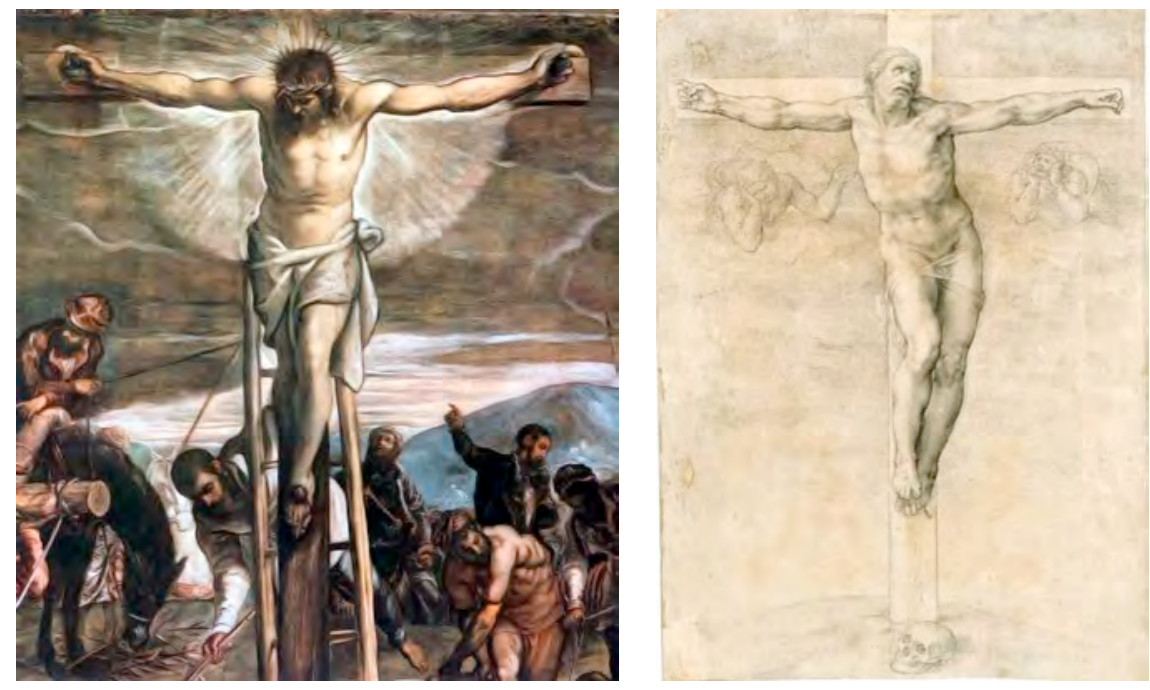

Fig. 33. a, b. Jacopo Tintoretto, Crist de Crucifixió de Crist, 1565, Sala dell'Albergo, Scuola Grande di San Rocco, Venècia; Miquel Àngel, dibuix del Crist crucificat, v. 1540, British Museum, Londres.

convers, ja sigui d'incògnit o sigui la seva identitat més publicitada. Uns i altres no dubten a cercar un bon lloc des d'on observar la tràgica escena.

Per veure sintèticament I'episodi, puc recomanar el dibuix que en va realitzar John Ruskin, Copy after the Central Portion of Tintoretto's "The Crucifixion» in the Scuola Grande di San Rocco, en la seva estada a Venècia el 1845, però també convé, per analitzar més minuciosament tots els detalls que integra aquesta gran pintura, servir-se d'alguns dibuixos que ens menen a Agostino Carracci (1580) i a les versions gravades a partir d'aquestes exploracions prèvies de la gran tela mural (1582-1589) i que, no cal insistir-hi, també la interpreten (figs. 34a, 34b i 34c). ${ }^{66}$

Les còpies del conjunt mostren fins a quin punt s'ha entès (o no) la proposta del venecià. Per exemple, la d'un anònim del segle XVII que porta les idees a un oli sobre tela de I'església de San Giacomo de San Domenico de Forli. Menor en dimensions, el pintor hi simplifica algunes propostes $\mathrm{i}$ regira I'escenari, cosa que fa avinent l'impacte dels gravats. En aquest cas, el contundent efecte que atrau Crist al primer pla es perd, ja que sobre el seu cap ha definit un arc de mig punt que configura una extensió en forma de lluneta, ideal per fer retrocedir la seva figura al pla que veritablement li corresponia però que no era el que Tintoretto havia buscat. Tanmateix, si hem d'explorar un cas en què el que es representa no sigui el clavament, sinó l'esforç per aixecar la creu, haurem d'anar a Nuremberg i descobrir un tríptic que mostra el moment en què Crist serà elevat, una
${ }^{66}$ Gravat de Roeland van Bolten, segons el disseny d'Agostino Carracci a partir de Jacopo Tintoretto. Vegeu-ne la reproducció en alta qualitat a: https://collezioni.genusbononiae.it/products/dettaglio/81. 
67 L'obra se situa vers el 1480-1490 i és un treball sobre fusta. Centre: $66 \times 48,3 \mathrm{~cm}$; cada costat: $66 \times 23,5 \mathrm{~cm}$.

68 A la part baixa del mural el pintor ha trobat la manera de crear dues plataformes excepcionals que generen un trompeI'oeil molt remarcable, que són la base del plany sobre el Crist mort i una espectacular resurrecció amb Crist volador. Res de nou en el vol en si, ja explorat en obres del segle XIV, però sí en el model que se segueix.

69 El gravat no seria, en tot cas, I'origen de la representació del tema, que remet, tal com hem vist, a obres anteriors al segle XVI.

70 Charles de Tolnay, Hieronymus Bosch, Nova York, Antabras, 1966; R. Alcoy, El Bosco en..., en premsa. acció en què no participen menys de vuit personatges. ${ }^{67}$ Les creus dels Iladres encara són a terra i, per tant, han d'esperar resignats que arribi el seu moment al batent dret del conjunt, oposat al que ocupen les Maries i sant Joan.

Ja sabem que la idea d'assistir al clavament de Crist a la creu té els seus precedents, però ara són els malfactors que l'acompanyen els que han estat elegits per descriure una tal situació. Crist també havia estat clavat d'altres maneres que implicaven una elevació prèvia de la creu, com en el cas del mural de San Colombano, ja vers el 1600. Vincenzo Campi (15361591) va optar per mantenir la idea del Crist clavat mentre la creu era encara a terra en una pintura que pertany al Museo del Prado; el mateix que, temps abans, havia plantejat Giovanni Antonio de Sacchis, Il Pordenone, en el seu Cristo inchiodato alla croce del Duomo di Cremona (1520) (fig. 35), un cas en què la baralla entre els soldats que es juguen la túnica es precipita a mà esquerra amb la presència de ganivets i punyals, com en I'antiga tradició germànica que s'havia divulgat a l'entorn del 1400 fins a arribar a Catalunya. Si observem el Calvari del mateix cicle (v. 15201521), acusadament expressionista i creador de detalls molt singulars, veurem que les tres creus són clavades en els espais corresponents del Gòlgota i que un botxí procedeix ja a trencar les cames dels Iladres. ${ }^{68}$ Som Iluny del planteig de Tintoretto en aquest particular, encara que tots aquests precedents de Calvaris poden interessar a I'hora d'interpretar algunes de les imatges del Calvari de San Rocco, molt especialment consternat per les llums i les tensions teatrals.

Sigui com vulgui, no convé deixar de mirar al nord, perquè és en una Crucifixió de Pieter Bruegel el Jove, del 1617, on advertim un joc amb les creus dels lladres, que encara s'han d'acabar de disposar i encaixar en I'espai que els pertoca. No es tracta de disposar Jesús en la creu, fet que resulta més comú en la iconografia del tema i tornarà a interessar a Hans Baldung Grien per il.lustrar un Espill de la Passió de Crist. ${ }^{69}$ Aquesta escenografia pot haver estat avançada per obres anteriors als Països Baixos i, sense haver fet una revisió prou exhaustiva, és força clar que el Bosch ja havia pensat en el tema. Ho demostra la grisalla de I'exterior del tríptic de l'Adoració dels reis de l'Orient del Museo del Prado. La creu del Iladre que es condemnarà no és encara a lloc i es descriu només la seva ascensió pel Camí del Calvari. Aquest espai simbòlic que separa els benaurats dels penats a l'infern serà ocupat per Judes, que es penja de l'arbre. ${ }^{70}$

Sobre el grup de les dones que acompanyen, en el primer terme, la Mare de Déu, encara cal posar-hi l'accent per advertir que no són solament les tres Maries, les que s'han apropat a l'indret. Ara no disposo d'espai per desenvolupar adequadament aquesta interessant qüestió que en terres ita- 

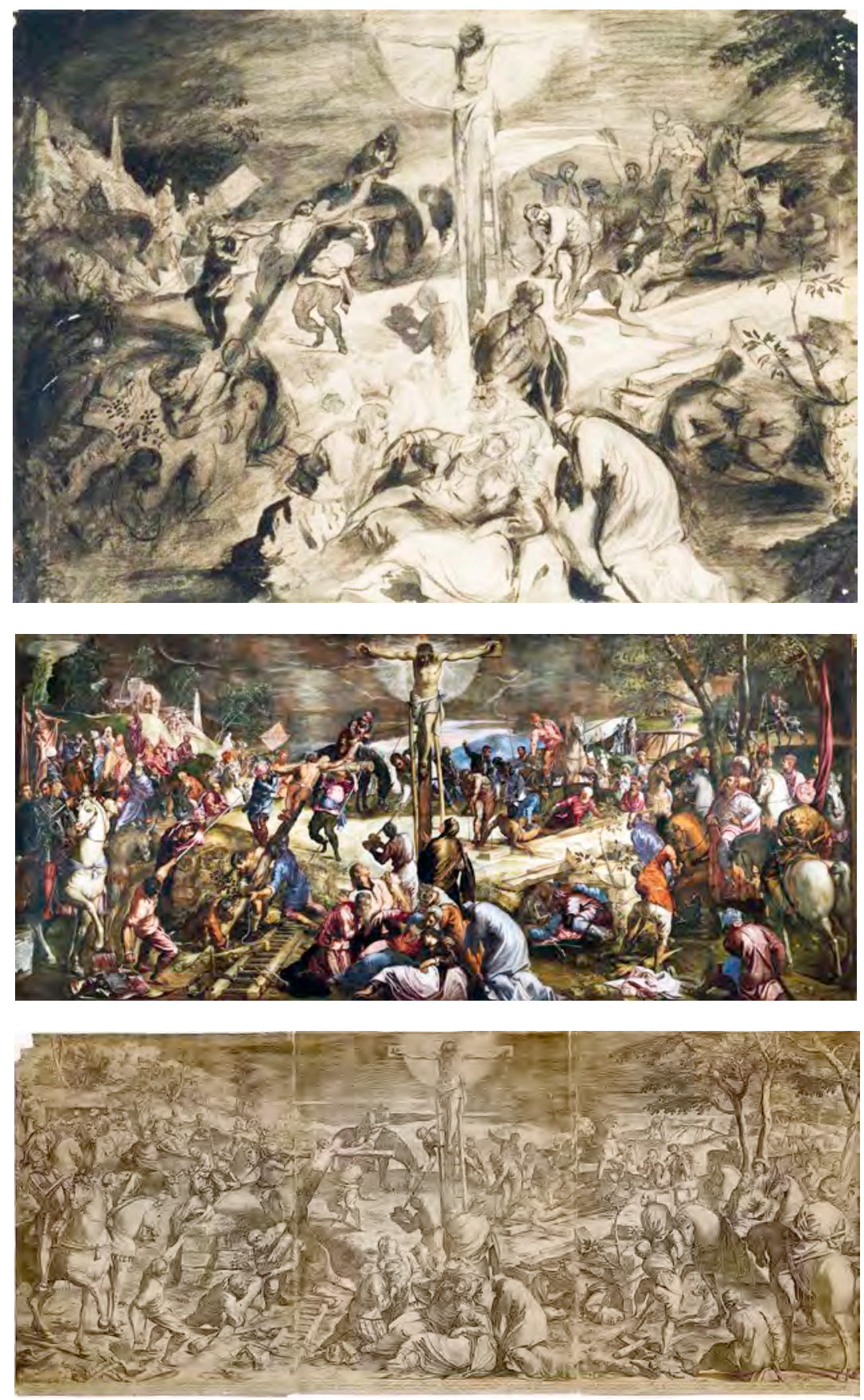

Fig. 34. a, b, c. John Ruskin, còpia de la part central de la Crucifixió de Tintoretto a la Scuola Grande di San Rocco, v. 1845; Tintoretto, Crucifixió de sant Roc i gravat de Roeland van Bolten realitzat a partir dels dibuixos d'Agostino Carracci. 
71 Rosa Alcoy, «Una propuesta de relación texto-imagen: "Las madres de los Santos Inocentes" y la iconografía de la pasión en la pintura italiana del siglo XIV», D'Art, núm. 11, 1985, p. 133-162.

72 Me n'ocupava més recentment a R. AlcoY, «Ideas para lo ordinario...».

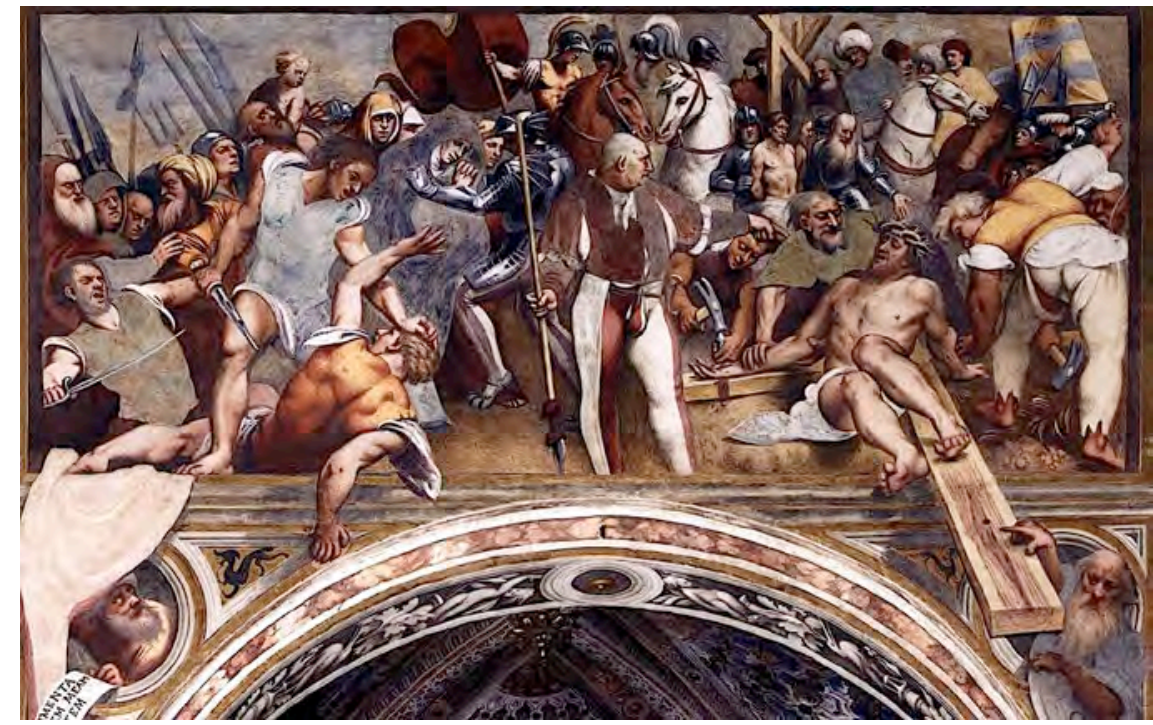

Fig. 35. Il Pordenone, Cristo inchiodato alla croce, v. 1520, Duomo di Cremona.

lianes va gaudir de gran fortuna ja des del segle XIII, però remeto a un estudi precedent on es valoren les possibilitats d'interpretació d'unes solucions que cal resseguir també dins I'època moderna, com tantes altres ja plantejades i planejades pels artistes del gòtic. ${ }^{71}$ Simplement recordaré que ja els Pisano, a les seves trones, inclouran el tema d'aquestes dones de més, dites de Jerusalem, que es poden relacionar amb les mares dels sants innocents i que la pintura acull també a Assís, tant al Calvari com al Camí del Calvari de Pietro Lorenzetti. ${ }^{72}$ En el cas de Tintoretto, és interessant relacionar aquest grup del desmai de Maria, que tomba vers I'esquerra, acollida en braços per una de les dones, mentre una altra sembla recolzada sobre ella, en una bella escena dels anys quaranta (v. 1547) dedicada a la història d'Ester i Assuer. El desmai de la primera, amb aparença més cortesana i tractament pictòric ric i preciosista (fig. 36), és un esment directe del tarannà més sever que escau per resoldre la imatge de Maria. Val la pena anar fins a l'Antic Testament, perquè el motiu fa també ben palès el paper de les dones del voltant $i$, en algun cas, revela la pròdiga aquiescència amb les fórmules del Veronès. També val la pena al-ludir, dins la mateixa Scuola Grande di San Rocco, a la Matança dels Sants Innocents, que ja en el tardà 1482 permet a Tintoretto redescobrir-nos el moment de la massacre, en la qual genera una excel-lent i renovada prefiguració de la mort de I'Innocent al Gòlgota (fig. 37). Els vols i les caigudes de les dones i I'eficàcia sense ànima dels soldats creen buits i zones de pas que atorguen a l'escenari una gran profunditat, i no només relativa a I'espai. La dona que té 


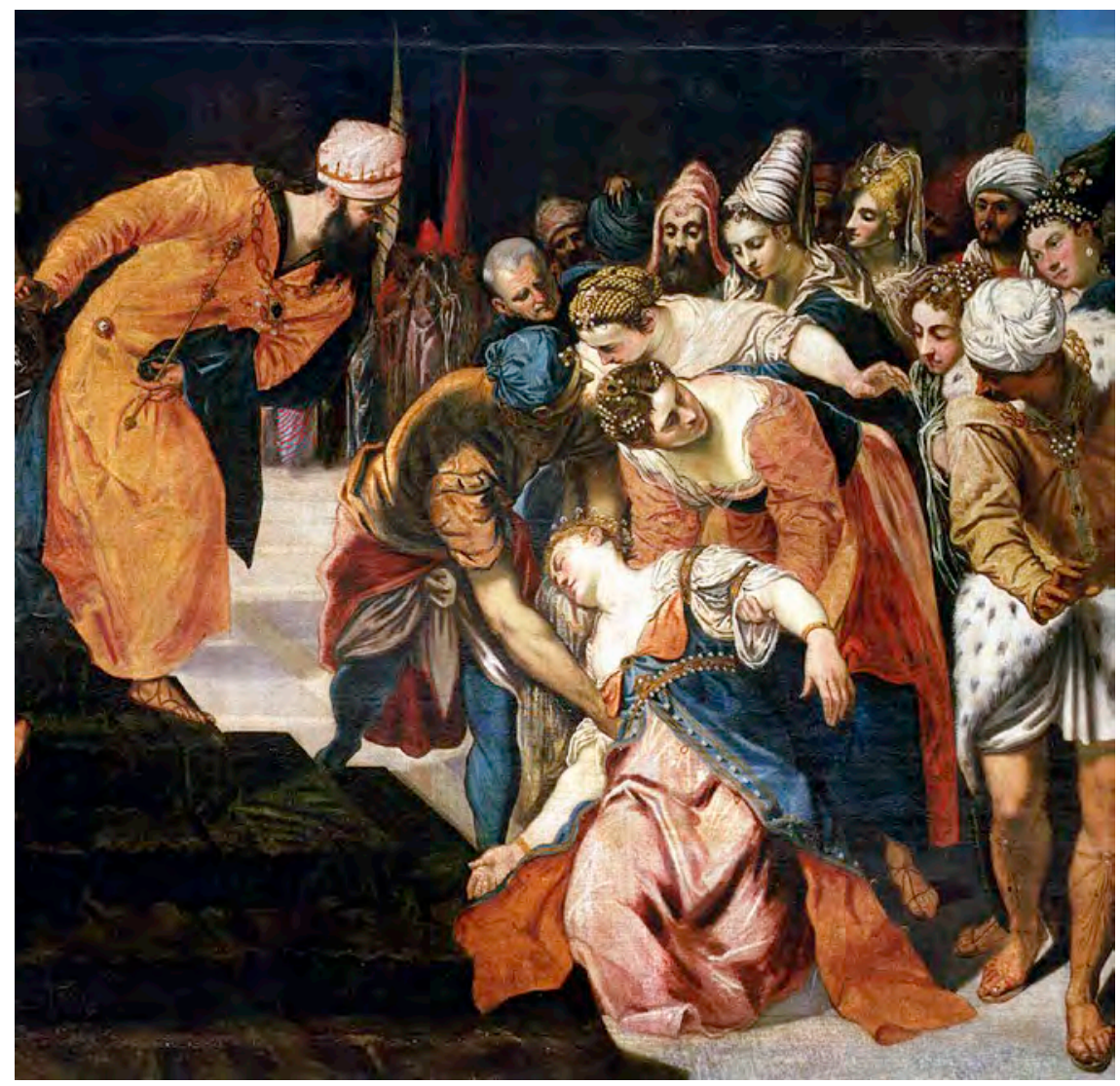

Fig. 36. Jacopo Tintoretto, detall d'Ester i Assuer, v. 1547, Royal Collection, Kensington Palace, Londres.

I'infant damunt la falda ens proposa una versió d'antics models alhora que exhibeix el plany d'aquella a la qual ja no cal lluitar per la vida del nadó.

A San Rocco, alguns autors han volgut relacionar amb les personificacions de l'Església i la Sinagoga, d'una banda, la dona dreta al peu de la creu $i$, de I'altra, una segona figura plausiblement femenina i completament coberta que sembla dur un barret al cap i que se situa, una mica ajupida, al costat dret del grup format per Maria i els fidels a Crist. Cap de les dues no es distingeix per atributs clars que assenyalin la seva identitat. Tanmateix, els que volen confrontar-les com a imatges de l'Església, en el primer cas, i de la Sinagoga, en el segon, no tenen en compte altres possibilitats molt ben installades en la tradició italiana. No podem oblidar ni les Maries, és clar, ni les mares que reclamen el retorn a la vida, si més no a l'eterna, dels seus fills innocents, morts durant els temps de la infància de Crist. En el primer cas, es passa a descriure dues protagonistes confrontades, Església i Sinagoga, amb 
un sentit antitètic que no repara en el dol comú i més aviat anònim al peu de la creu per tal de veure-hi les dues personificacions, d'ús simbòlic ben conegut en aquest context. Malgrat els canvis d'època, no s'acostuma a romandre indiferent a algunes precisions iconogràfiques que siguin prou clares i també exigibles perquè no facin dubtar de la identitat de les representants de la Nova i I'Antiga Llei. En aquest sentit i no sense tenir en compte la necessitat d'aprofundiment en aquest punt amb noves recerques sobre la «invenció» del tema en els temps moderns, la idea em sembla molt insegura.

Sobre el cap de Crist, il-luminat per darrere amb tintes blanques, encara és ben visible la corona d'espines. També s'ha pintat un INRI (Iesus Nazarenus Rex Iudaeorum) que sembla flotar sobre la creu. Les mans clavades remeten a la distància que separa les obres del segle XIII —amb claus que semblen punts $i d^{\prime}$ 'on ragen filets de sang molt ordenadamentde I'altar d'Isenheim de Matthias Grünewald (1512-1516), on les mans es recargolen amb els ossos i Iligaments en patir d'horribles ferides. El mateix es pot comentar del clau que travessa els dos peus superposats de Crist i que en I'obra de la Scuola di San Rocco fins permet entreveure la tècnica de fosa amb què ha estat realitzat. El volum del cos de Crist i el gir que prenen les cames en creuar-se, però essencialment la complexió dels braços i el moviment endavant del pit, haurien de ser deutors d'un conegut

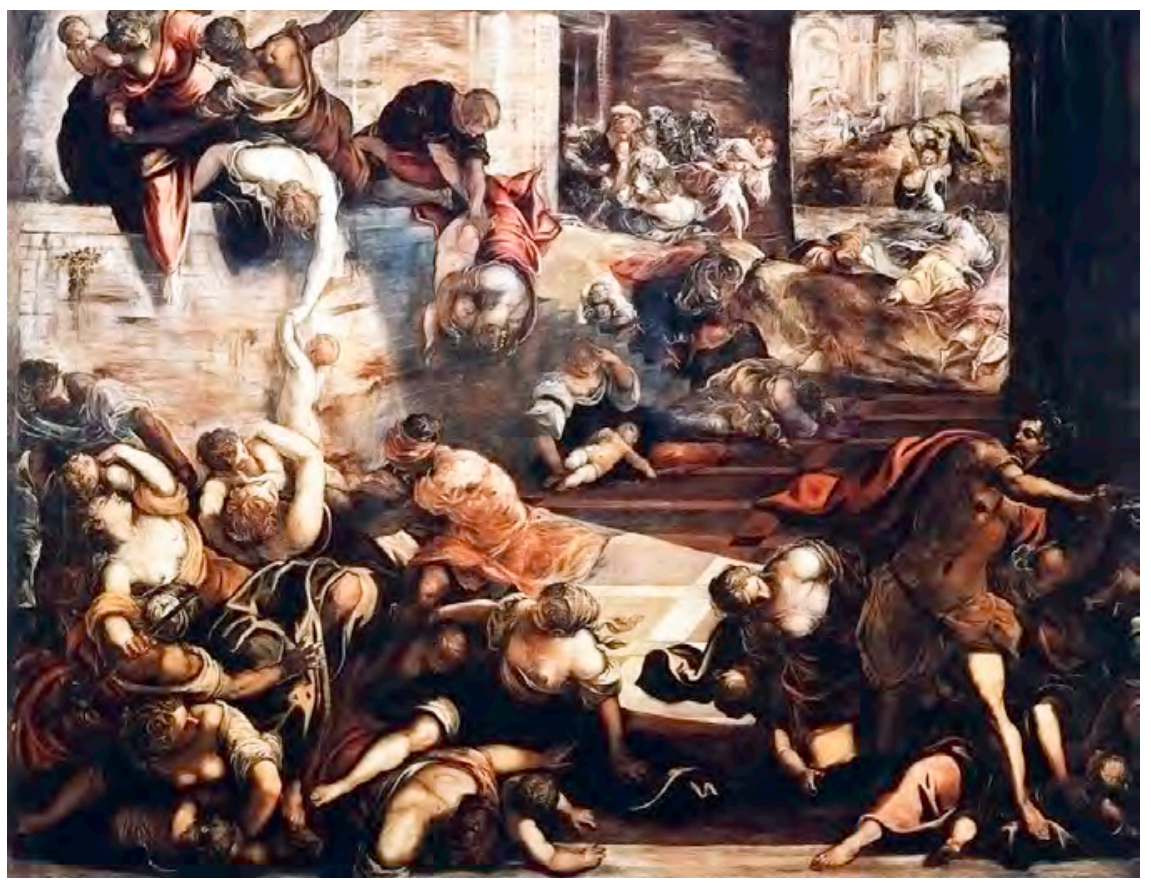

Fig. 37. Jacopo Tintoretto, Matança dels sants innocents, Scuola Grande di San Rocco, Venècia. 
dibuix, ja evocat, de Miquel Àngel (1475-1564) o d'un plantejament similar atribuïble al Buonarroti (fig. 33b). ${ }^{73}$ Tanmateix, és també palès que la seva fórmula no ha estat seguida fil per randa i Tintoretto hi suma una dimensió cromàtica que tendeix a dissoldre el travesser horitzontal per crear un Crist que sembla ben a punt de separar-se de la creu material. L'empenta endavant del pit és clara i es veu ajudada per l'impuls dels braços i la ja comentada ubicació de la creu, a recer del marc superior. La Ilum, tot i els tons blanquinosos, pren autoritat solar, la d'un astre irradiant que, malgrat que quedi tallat pel límit superior, envaeix el tors i encercla la figura de més de mig cos en amunt. Es retorna al Crist «esculpit», amb el drap blanc que es nua als malucs, i a través d'ell, a l'orbe de la divinitat trinitària que representa el cent per cent del seu potencial pictòric. Això explica que la figura isolada al capdamunt de la creu sigui capaç $d^{\prime}$ il.luminar per si sola una part notable de l'escenari inferior, per esdevenir també salvaguarda i exposició palesa de la divinitat del sacrificat. En aquest punt val la pena comparar el Crist amb les representacions de la Paternitas que el mateix Tintoretto i el seu taller haurien creat. La més propera a la visió encarnada a l'Albergo és, en tots els sentits, la Trinitat de la Galleria Sabauda de Torí, devers 1564-1568, en oli sobre tela (122 × $181 \mathrm{~cm}$ ) (fig. 38), encara que també es pugui evocar de l'escola veneciana relacionada amb Tintoretto una Paternitas força més tardana (v. 1590) vinculada a la Samuel H. Kress Foundation, que adopta un punt de vista per al Crist més proper al del Calvari de la Sala dell'Albergo, però que ja no respira el seu mateix aire.

En la Ilunyania del Calvari de San Rocco hi ha qui assenyala Crist mentre el fons s'ha anat cobrint d'un mantell espès de núvols de color beix, picat de groc, que, enfrontat a la llum del pla de terra, pot arribar a semblar grisós. El cel enterbolirà aquest final que el pintor vol iniciàtic i invasor en els seus primers termes per retrobar la continuïtat en les escenes de glòria. Tot i la relativa foscor general, no s'estalvia res que li permeti posar accents cromàtics suaus i sumptuaris.

En el terme més allunyat, els detalls serien Ilargs d'explicar en la seva totalitat, però em crida I'atenció I'estudi del grupet de tres cavalls de coloracions marró i gris que es miren i que gairebé es diria que dialoguen entre ells a la banda dreta del quadre, propers a un pont o passarel|la. No gaire Iluny hi ha un quart i un cinquè cavalls de color blanc i pentinats refistolats que pertanyen al prosceni, al costat d'una muntura molt més grossa del mateix color que trepitja la pedra clara. El seu genet dirigeix les accions i es farà responsable de les cordes que elevaran la creu de Gestes, el mal Iladre. El cavaller és extraordinàriament modern en el pla pictòric. Tintoretto aconsegueix fer elàstiques totes les parts del seu esquelet, que des-
73 El dibuix es relaciona $a m b$ una pintura de col·lecció privada que es planteja identificar amb el Crucificat destinat a Vittoria Colonna, segons hipòtesi de Lionello Puppi presentada a Finestre sull'Arte (23-2-2016) i en altres mitjans. L'obra, amb corol-laris diversos, es correspon molt fidelment amb el dibuix al carbó, configurat com a Christus triumphans o vigilans, que pertany al British Museum de Londres. 
74 Ens faciliten una transició brillant de les escenes de la infància a les de la Passió. En tot cas, hi ha altres lectures que també es poden avaluar: Elizabeth CARRoll CONSAVARI, "Tintoretto's holy hermits at the Scuola Grande di San Rocco», Michelle A. ERHARDT, Amy M. Morris (eds.), Mary Magdalene, Iconographic Studies from the Middle Ages to the Baroque, Leiden/Boston, Brill, 2012, p. 135-160.

75 Sobre el seu sentit i la seva presència a Venècia i a I'antic món romà, podeu veure: $\mathrm{A}$. MANNo, Tintoretto. La Crocifissione..., p. 15.

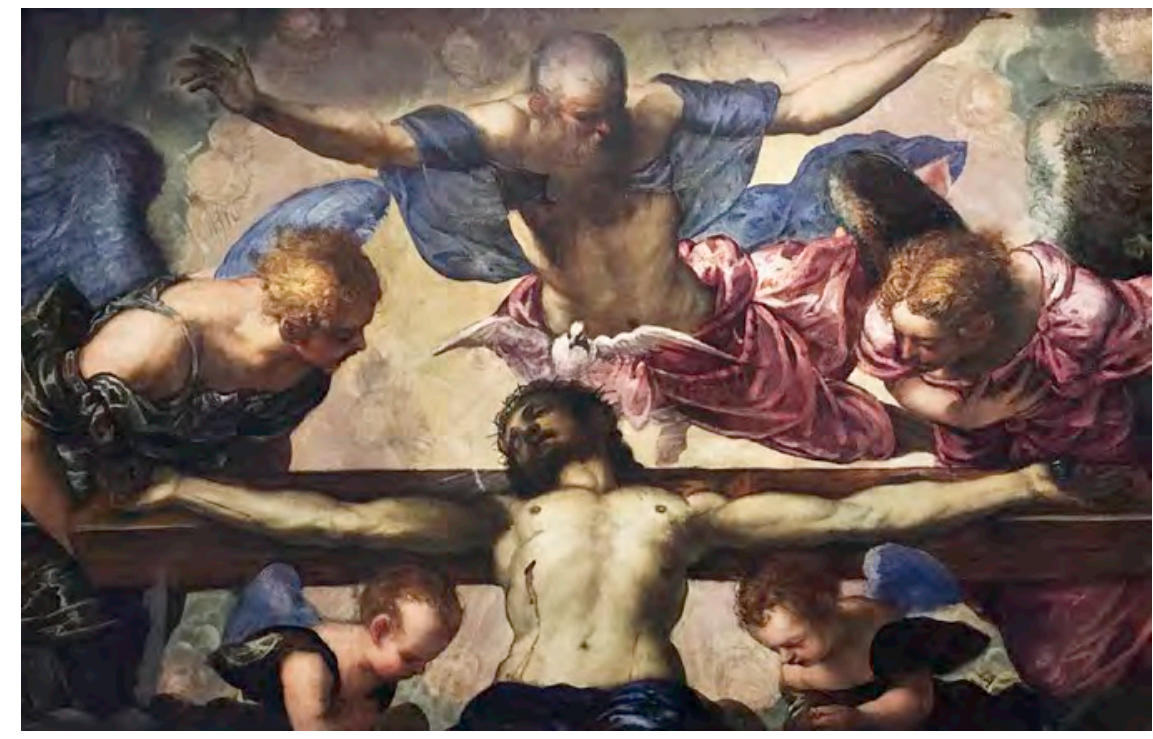

Fig. 38. Jacopo Tintoretto, detall de la Trinitat, v. 1564-1568, Galleria Sabauda, Torí.

apareix sota les teles teixides pel sentit del moviment a sàvies pinzellades. Sobre el cavall, la figura guanya una monumentalitat dinàmica que ordena la zona, on són molts els elements integrats. Compareixen a l'esquerra, sobre un fons en què el passatge de les imatges humanes més aviat espectrals es converteix en ingredient de transició a figures i espais encara més distants que s'insinuen i preludien mirades sobre la natura que reeixiran més tard, ja als anys vuitanta, gràcies a les dues excel·lents vistes que tendeixen a relacionar-se ara amb la figura de Maria lectora, a la planta baixa de la Scuola Grande di San Rocco. No sembla impossible que es tracti del mateix personatge vist pel davant i pel darrere. La invenció icònica garanteix a Tintoretto la generació de dos paisatges excepcionals que, en plena restauració el 2018, poden molt bé reflectir les meditacions de Maria, o de la dona santa, i revertir en el sentit que adquireix, en aquest context de la Scuola Grande, la història de la salvació. ${ }^{74}$

A l'altre costat del Calvari s'aixeca un lloc encastellat, que s'identifica amb el perfil de Jerusalem i la fortalesa Antònia, on es podria emplaçar el Judici a Crist, ja que allotjava el pretori de Pilat. Al costat veurem un monòlit o obelisc que eleva la punta rere la muntanya ${ }^{75}$ tot plegat fa de repoussoir d'un grup fantàstic d'homes i dones amb vestuaris orientalitzats. Uns aires bizantins o orientals Ilunyans en el temps i I'espai, que figuren una mena d'harem en què no manca la imatge $d^{\prime}$ 'algun petit infant, encavalquen així amb unes notes de curiosa actualitat. Avancem en la direcció que avancem, xocarem de nou amb els cavalls i els soldats que circumden aquest 
espai cinematogràfic on l'acció reina, igual que ho fa dissimuladament un airet que fa moure les copes dels arbres i les crineres dels cavalls.

Abans de crear aquest espectacle, Tintoretto va tenir la possibilitat de fer altres assaigs on calia resoldre el mateix tema. Un dels més interessants és la Crucifixió de I'església de San Severo (1555-1558 (?)) del Dorsoduro, que es conserva a les Gallerie dell'Accademia (fig. 39). ${ }^{76}$ En aquesta obra es pot apreciar el lleu desplaçament a l'esquerra del grup de les Maries que portarà, uns deu anys més tard, a la valenta solució de San Rocco. La disposició de I'escala encara beu d'esquemes anteriors i la situació dels soldats es revela farcida d'intencions, amb un grau de protagonisme que manifesten també cadascuna de les figures secundàries, o no tan secundàries, com ara el soldat de l'estendard immens, una mena de gegant que pot emular qualsevol sant Cristòfol, o la parella de soldats que es jugarà la túnica mentre una dona, creadora d'una iconografia ben singular, els observa. ${ }^{77}$ Els cavalls hi són, però només a I'esquerra, un gran animal blanc planta cara al primer terme, mentre que la llunyania està feta i disposada perquè hi detectem els testimonis i curiosos, alhora que advertim el desplaçament atípic damunt de la creu del lladre realment malfactor, que hi apareix sobreposat. Les tres creus no són pas tan altes com a San Rocco i tots els plans compareixen comprimits. Tot i així, alguns dels elements ja tenen quelcom del potencial que es desplegarà a la Scuola Grande di San Rocco. Aprofitem per anotar que imatges fantasmagòriques com les del Baptisme de Crist, on el rerefons espectral permet prefigurar el demà de

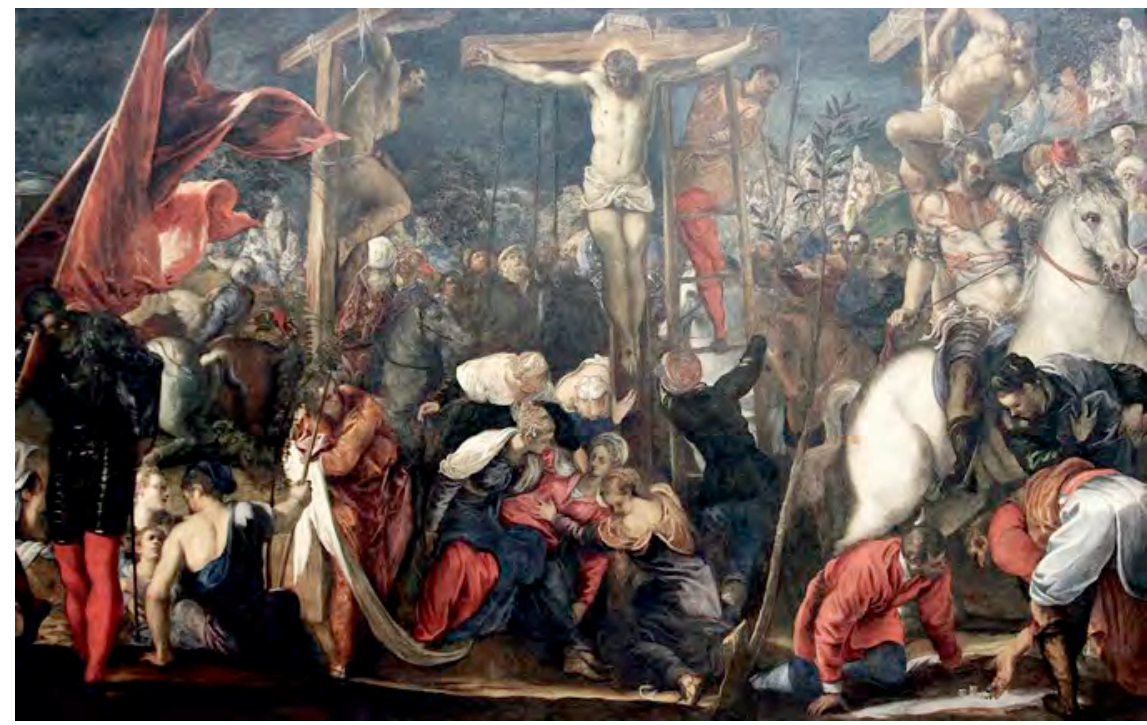

Fig. 39. Jacopo Tintoretto, Crucifixió de l'església de San Severo, v. 1555-1558, Gallerie dell'Accademia, Venècia.
76 Es considera, a partir de fonts i comentaris patrístics, que Maria pateix els dolors del part, aquells que no ha experimentat abans, quan arriba el moment de la mort de Crist. El seu ventre inflat, es diu, apuntaria en aquest sentit. Sobre la dimensió teatral de I'obra de Tintoretto, vegeu Sergio MARINELLI, «Aspetti della teatralità nell'opera di Jacopo Tintoretto», P. Rossi, L. PuPPI (eds.), Jacopo Tintoretto nel quarto..., p. 263-266.

77 Vegeu el dibuix preparatori d'aquests personatges que juguen a daus, no clarament vestits com a soldats, a Michiaki KoshIKAWA, "Disegnatore», R. Echols i F. ILChMAN (eds.), Tintoretto..., p. 171-189, esp. p. 180, on també es poden recuperar alguns esbossos preparatoris o estudis per a figures presents al Calvari de la Scuola Grande di San Rocco (p. 182). 
78 L'església Dei Gesuati va ser construïda del 1726 al 1735 i va ser decorada per Giovanni Battista Tiepolo.
Maria al peu del Calvari, rondaran els escenaris fins a fer-se imprescindibles en el Ilenguatge figuratiu del pintor. La fortalesa del Crist és una d'aquestes premonicions de I'obra posterior, una altra es revela al grup de les dones al voltant de Maria, inclosa una tímida translació vers el frontis de la creu, i la tercera, si només n'hem de triar tres, la reservaria a l'estudi dels personatges que, com els jugadors, omplen I'angle inferior dret.

Es coneix encara una obra anterior consagrada al Calvari que, amb un bonic paisatge urbà al fons que relata els moments previs i situada vers el 1540-1545, pertany al Museo Civico de Pàdua i va ser atribuïda a Tintoretto per Fiocco i a Dario Votari per Venturi. L'obra no té el gruix pictòric de les dues anteriors i pateix $d^{\prime}$ 'algunes inconsistències gràfiques, però no puc passar per alt el fet que la Mare de Déu, acompanyada per una de les Maries, i una Magdalena inequívoca, amb el mantell vermell caigut sobre les cames i els cabells llargs trenats i visibles, s'emplaci just al peu de la creu. La tercera de les Maries, ja que no hi ha dones sobreres en aquest cas, es troba dreta en segon terme, i hi ha altres detalls que no deixen de ser rellevants. No oblidem que al voltant dels inicis dels anys quaranta Giovanni Galizzi (actiu a Venècia el 1543 i mort el 1565) compareix com a pintor relacionat amb Tintoretto, en especial en la seva obra de 1547, Sant Marc entronitzat entre dos sants, signada i datada. La pintura concreta unes possibilitats artístiques que, com es palesa en la composició, no poden competir amb les habilitats de Tintoretto.

A Jacopo Tintoretto també correspon una Crucifixió o Calvari sintètic, ara a I'església de Santa Maria del Rosario o dei Gesuati (Venècia), devers 1560-1565 (?) (fig. 40). ${ }^{78}$ Ens apropem molt més a les dates del Calvari de la Sala dell'Albergo, i el grup de les Maries sembla ja definit amb un plus que les porta de ser quatre a ser cinc, inclosa la Mare de Déu, i sobretot a ocupar tot I'espai que deixava I'escenografia descrita al peu de la creu. Un altre aspecte rellevant que prefigura la imatge de San Rocco és l'embolcall Iluminós que aquí compareix com a sol quasi sencer, només aplanat una mica a la part alta per l'arc de mig punt que tanca el marc superior del plafó. Si comparem l'efecte amb una composició de Jacopo Bassano (1510-1592) del Museu Nacional d'Art de Romania, coincidirem segur a observar la distància que les separa i a apreciar el gruix que empara Tintoretto i que, en aquest cas, fins el pot acostar a l'esplèndid repertori femení de Paolo Veronese. Una opció que no té pas en compte Jacopo Bassano, que empetiteix el Crist al capdamunt d'un Ilarg pal vertical. Una placa de coure de Giovanni Stradanus (placa de coure de $19 \times 26 \mathrm{~cm}$, v. 1580) ens situa novament i ens impedeix oblidar que la tradició de separar les coses existia. Tanmateix, Stradanus, tot i I'aparent respecte amb 
què dibuixa l'esquerra i la dreta de la composició, altera la disposició del joc de la vestimenta de Crist, que emplaça en un espai situat a l'esquerra de la pintura, on normalment hauríem pogut trobar les Maries.

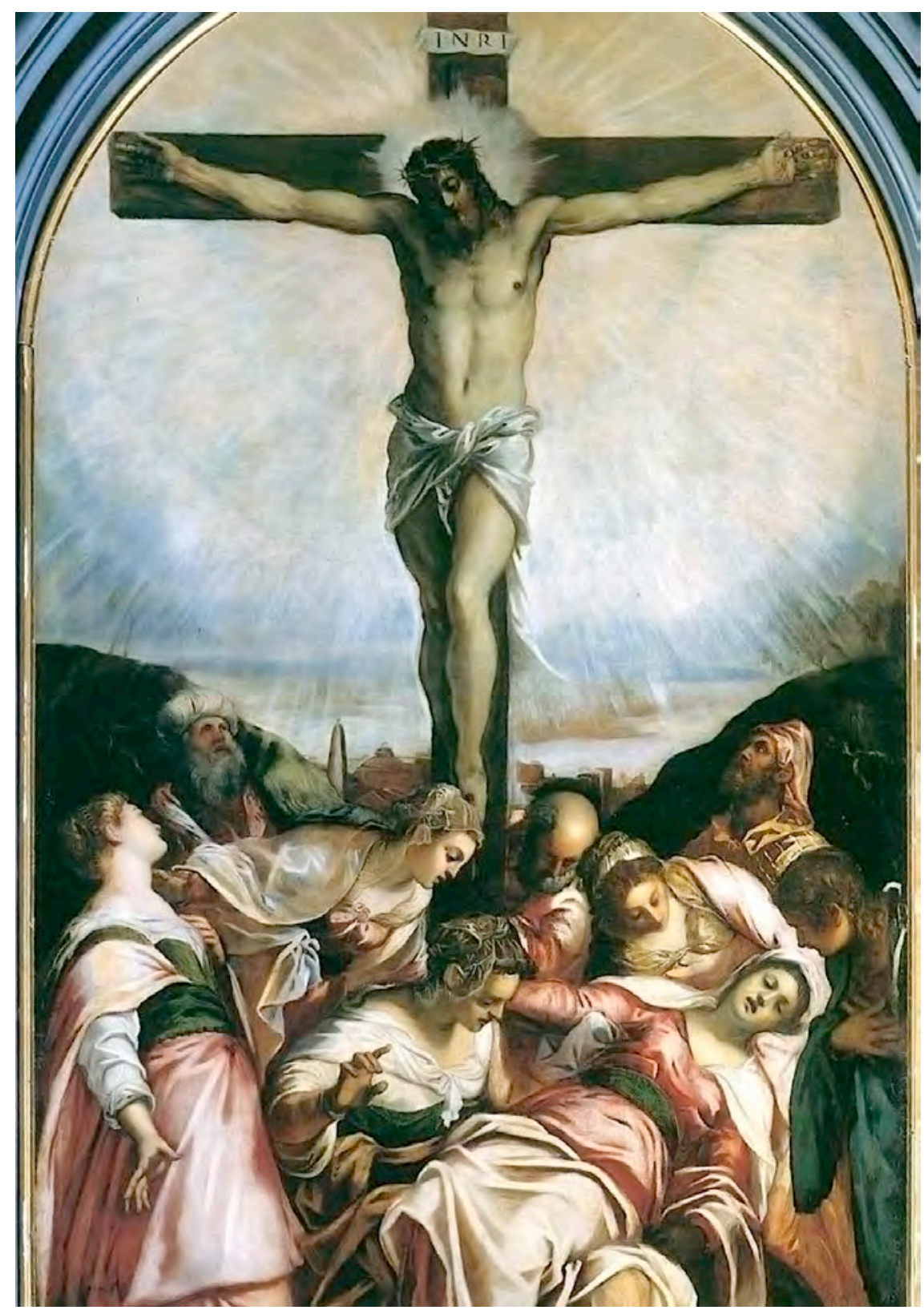

Fig. 40. Jacopo Tintoretto, Crucifixió de l'església de Santa Maria del Rosario o dei Gesuati, v. 1560-1565, Venècia. 
79 Per a aquesta pintura i els seus lligams amb Rafael i altres artistes, vegeu R. ECHOLS i F. ILCHMAN (eds.), Tintoretto..., p. 5-12.
La Crucifixió de San Cassiano de Venècia, v. 1568, és una obra de mides grans $(341 \times 371 \mathrm{~cm})$ i més tardana, en la qual es perfilen les tres creus escorades a un costat i s'emfatitza la visió de perfil. La visió obliqua afavoreix que dues escales dibuixades fent tisora obrin l'espai davant i darrere dels crucificats, als quals s'acosta el portaesponja amb la cartel.la al-lusiva al rei dels jueus, INRI, que un segon personatge, enfilat al capdamunt de l'escala, haurà de fixar a la creu. Maria entaula un diàleg directe amb la creu de Crist, malgrat trobar-se ajaguda i assenyalar a terra mentre sant Joan se n’ocupa, i el mantell de Jesús roman, amb les seves tonalitats vermelles, abandonat al peu de la creu (fig. 41). Els soldats armats són ensotats en un prosceni que envolta l'escenari principal, creat per l'àmplia plataforma clara. Per tant, els romans queden molt per sota del punt de vista elevat que s'enregistra per a les creus i, sota un cel expressiu i amb colors canviants, alcen molt més les llances que els caps. Sobre aquesta forma d'emplaçament dels crucificats de San Cassiano es podria recordar un fragment del Calvari de la Pinacoteca Nacional de Bolonya, vinculat a Tiziano (v. 1564), i sobretot el plantejament de Paolo Veronese al Calvari del Museu del Louvre, però aquest arrana les figures al costat oposat i és una obra molt posterior que ens emplaça al voltant del 1582.

El Tintoretto havia afermat la seva marxa imparable vers la celebritat amb Il miracolo dello schiavo o Miracolo di San Marco, obra devers el 1548, a les Gallerie dell'Accademia, procedent de la Scuola Grande di San Marco. ${ }^{79}$ Es tracta d'una pintura on I'espectacular descens del sant trasbalsa la realitat inferior, que s'eixampla i s'aixeca per ambdós costats, dret i esquerre. A la banda dreta veiem la figura asseguda que titllaria de premonició del Pilat de San Rocco, alhora que el fons prepara el Rentament de peus del Prado, que admet consonàncies clares amb aquest treball. El cos de I'esclau és una molt bona introducció a la Descoberta del cos de sant Marc (un dels miracles del sant que implica, a més, la resurrecció d'un mort i l'exorcisme d'un posseït) i al Trasllat del cos de sant Marc, que retrobarem més endavant (fig. 42).

El taller de Tintoretto introduiria en el seu repertori I'Adoració de la Creu amb els sants Andrea, Helena, Bàrbara i Macari i un parell de donants, no identificats, en una obra del voltant del 1560 de la Pinacoteca di Brera de Milà, que ens acosta a Nicolas Beatrizet, anomenat Il Beatricetto, i a la seva CRUX ILLUSTRIS AVE CHRISTI CRUX INCLITA SALVE | CRUX INSIGNIS AVE, CRUX BONA SEMPER AVE, divulgada des de la Roma del MDLVII. $S$ 'ha arribat a dir que «il dipinto è un tipico "prodotto" della Controriforma: in quest'epoca il culto della croce conobbe una vasta diffusione e, di conseguenza, si diffusero anche pale e opere che raffiguravano santi con 


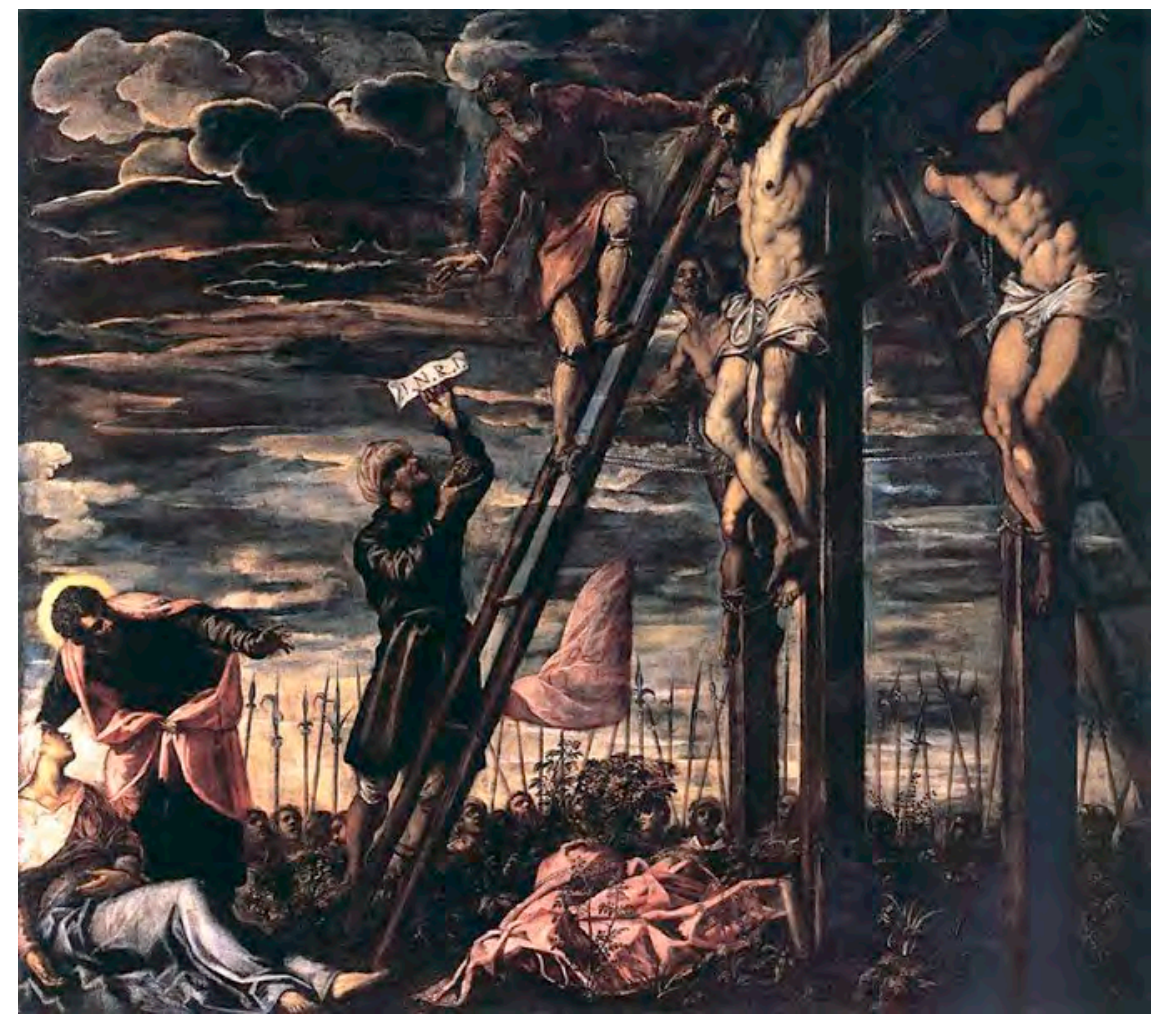

Fig. 41. Jacopo Tintoretto, Crucifixió de San Cassiano, v. 1568, Venècia.

nessi alla croce di Cristo. Quella del Tintoretto è per tanto un'opera piuttosto allineata e convenzionale, e si distingue soprattutto per I'uso della luce che sottolinea i volti dei santi e illumina con tonalità crepuscolari un cielo solcato da grandi nuvole, e anche per la stretta aderenza al vero con la quale certi volti vengono resi: basti osservare quello del devoto, un vero ritratto dell'ignoto committente $» .{ }^{80}$ Cal obrir les finestres a l'art medieval per adonar-se que el que es considera aquí un típic producte de la Contrareforma no és sinó una mostra més d'uns esquemes Ilargament explorats en els segles medievals, ja sigui a partir de les figures dels sants que abracen la creu, com ara Maria Magdalena o sant Francesc, de les creus envoltades per clergues i devots que travessen vers l'Orient amb esperit de devoció i litúrgic de gran volada, o de les productives pintures gòtiques que avalen seguiments similars, ja sigui per part d'apòstols, de sants i santes 0 de mortals no tan ben valorats. ${ }^{81}$

La serp de bronze de I'Antic Testament enfilada a una creu travessa el tema vinculat a Moisès i remet a la Crucifixió per regentar el decurs de la mort, el qual haurà de trobar el seu contrapunt esperançat com a triomf de
80 Extret de Finestre sull'Arte: https://www.finestresullarte.info/operadelgiorno/2017/ 646-tintoretto-santi-in-adora zione-della-croce.php

81 No debades, Ch. DE TOL$N A Y$, «L'interpretazione dei cicli pittorici di San Rocco», Critica d’Arte, núm. 7, 1960, p. 341376, ja qüestionava l'art de Tintoretto com a art de la Contrareforma. Per a l'emmarcament medieval, remeto a R. ALcoy, Anticipaciones del Paraíso..., esmentat a la nota 59. 

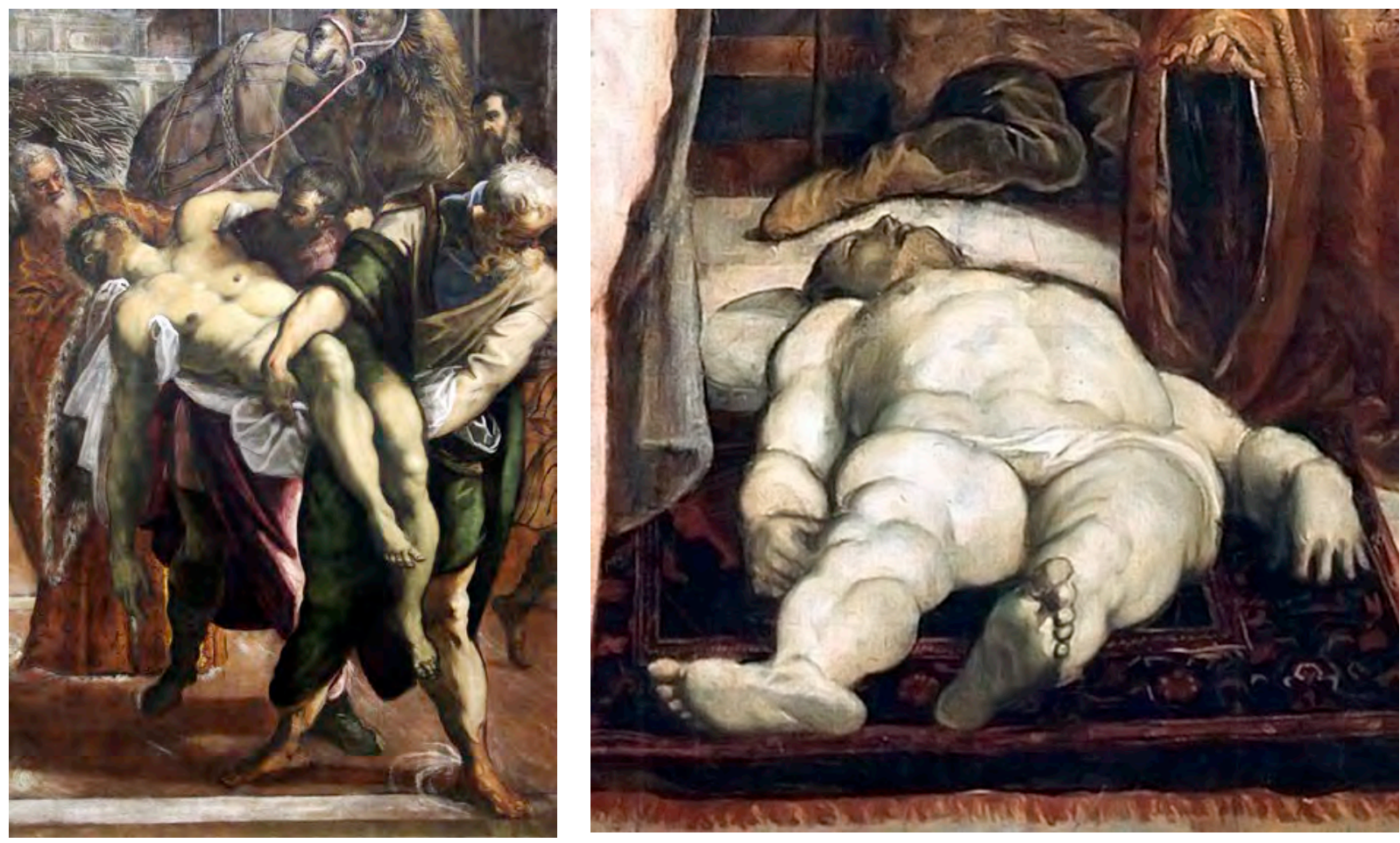

Fig. 42. a, b. Jacopo Tintoretto, detall del Trasllat del cos de sant Marc i detall de la Descoberta del cos de sant Marc, Scuola Grande di San Marco, Venècia.

82 Sobre les dimensions que cobra la pintura en el context general de la Scuola, vegeu Ch. DE TOLNAY, «L'interpretazione...», i el treball d'E. HutTinGER, Die Bilderzyklen Tintorettos in der Scuola di S. Rocco zu Venedig, Zuric, Buchdruckerei der Neuen Zürcher Zeitung, 1962.
Crist sobre aquesta darrera. Sense poder entrar ara en el complex sistema de figures i contrafigures que vinculen I'Antic i el Nou Testament, també a I'escenari de San Rocco, ${ }^{82}$ farem cap a I'església de la Madonna dell'Orto, a Venècia, només per apreciar nous aspectes del sistema operatiu que obre escletxa en el discurs de Tintoretto. La representació de les dues escenes dedicades a sant Pere i sant Pau facilita posar en evidència algunes d'aquestes claus. Mentre sant Pere assisteix a la visió de la creu que transporten els àngels, amb els atributs que el defineixen -les claus, el Ilibre i la tiara-, sant Pau està ben a punt de ser decapitat quan un àngel ja baixa del cel a retre-li honors amb la corona i la palma. Amb dos fragments extrets de les respectives històries dels sants, Tintoretto encreua continguts i extreu la síntesi d'allò que pot ser capital per a ambdós personatges: la fidelitat a la creu i el martiri. No cal, per tant, incloure en aquest sintètic frontis l'episodi de la mort de Pere, que ja simbolitzarà el del seu company més habitual amb prou claredat, encara que els suplicis no siguin idèntics. 


\section{Del Davallament a l'Enterrament de Crist}

Les pintures de la Sala dell'Albergo descriuen un punt culminant en la trajectòria de Jacopo Tintoretto. ${ }^{83}$ La seva execució havia de contribuir poderosament a la fama del pintor i consolidar la seva posició en la Venècia de la segona meitat del segle XVI. L'activitat del taller de Tintoretto a la Scuola Grande di San Rocco arriba fins al $1588^{84}$ i aporta obres i nous cicles de gran interès que resulta impossible exhaurir. Encara que no tot Tintoretto sigui Tintoretto estrictament, interessa molt veure el catàleg general de I'obra vinculada al pintor per fer-se càrrec de l'evolució de determinades escenes. ${ }^{85}$ D'altra banda, si volem resseguir les escenes pintades per Tintoretto que donen continuïtat al Calvari, haurem d'abandonar I'espai dedicat a sant Roc per retrobar altres creacions d'alt interès. Qualsevol seguiment de la seva concepció de la Passió de Crist implica un itinerari dens en idees i noves concepcions. Sense pretendre ser exhaustiva, faré la revisió d'algunes d'aquestes propostes que ens permeten avançar temàticament i que al mateix temps van configurant iconografies fora de la llei. Els temes adquireixen un aire diferent que ens interpel.la i interroga també el panorama artístic present i futur, amb ancoratges que tampoc no es poden menystenir en la tradició anterior.

El Davallament de Crist de la creu del Musée des Beaux-Arts de Caen descriu un model que es retroba amb pocs canvis en el Davallament del Musée des Beaux-Arts d'Estrasburg, atribuït a un Tintoretto avançat, devers 1575-1580 (figs. 43a i 43b). Aquests treballs en oli sobre tela no són idèntics, però la interdependència és clara. Bàsicament, es podria afirmar que trenquen amb la concepció bizantina del tema que encara es pot percebre en un conegut Davallament de Pietro Lorenzetti a la basílica inferior d'Assís i que serà seguit genèricament i amb múltiples canvis en composicions renaixentistes i barroques. Si el pintor de Siena i també altres pintors de I'època moderna havien frisat per mantenir el Iligam clar entre els fidels i el moment de recuperar el cos de Crist, que ha de ser baixat de la creu, Tintoretto trenca amb aquest desig i planteja ben separadament en les obres de Caen i Estrasburg dues circumstàncies abans associades. Fa visible un tall entre els grups que s'impliquen en l'acció. D'una banda, tenim els homes que baixen Crist per una escala amb un esforç considerable i els raonables equilibris, i uns altres que preparen la mortalla, que estenen a manera de Ilençol al peu de la creu. De l'altra, es genera el grup que encercla Maria, desmaiada a terra. Els fons varien, i també algun altre personatge, però l'esquema es repeteix.

Un tercer complex per considerar, del 1559-1562, ara de les Gallerie dell'Accademia veneciana (oli damunt de tela, $227 \times 294 \mathrm{~cm}$ ), ens permet
83 Per la Crucifixió hauria cobrat 250 ducats, pagats per Jerome Rota en representació de la Scuola, però arribaria a cobrar fins a 2.447 ducats, entregat a una empresa que, sense sortir de San Rocco, suposaria la realització de més de cinquanta pintures diferents que integraven tota mena de temes bíblics i religiosos.

84 Des del 1560 Tintoretto es fa també present al Palau Ducal i més endavant assumeix, no sense alguns entrebancs i ja vers el 1588-1592, I'encàrrec de I'enorme llenç dedicat al Paradís, de set metres per vint, creat per a la Sala del Consell Major.

85 Rodolfo Pallucchini, Paola Rossi, Tintoretto. Le opere sacre e profane, 3 vols., Milà, Electa, 1982-1990. 

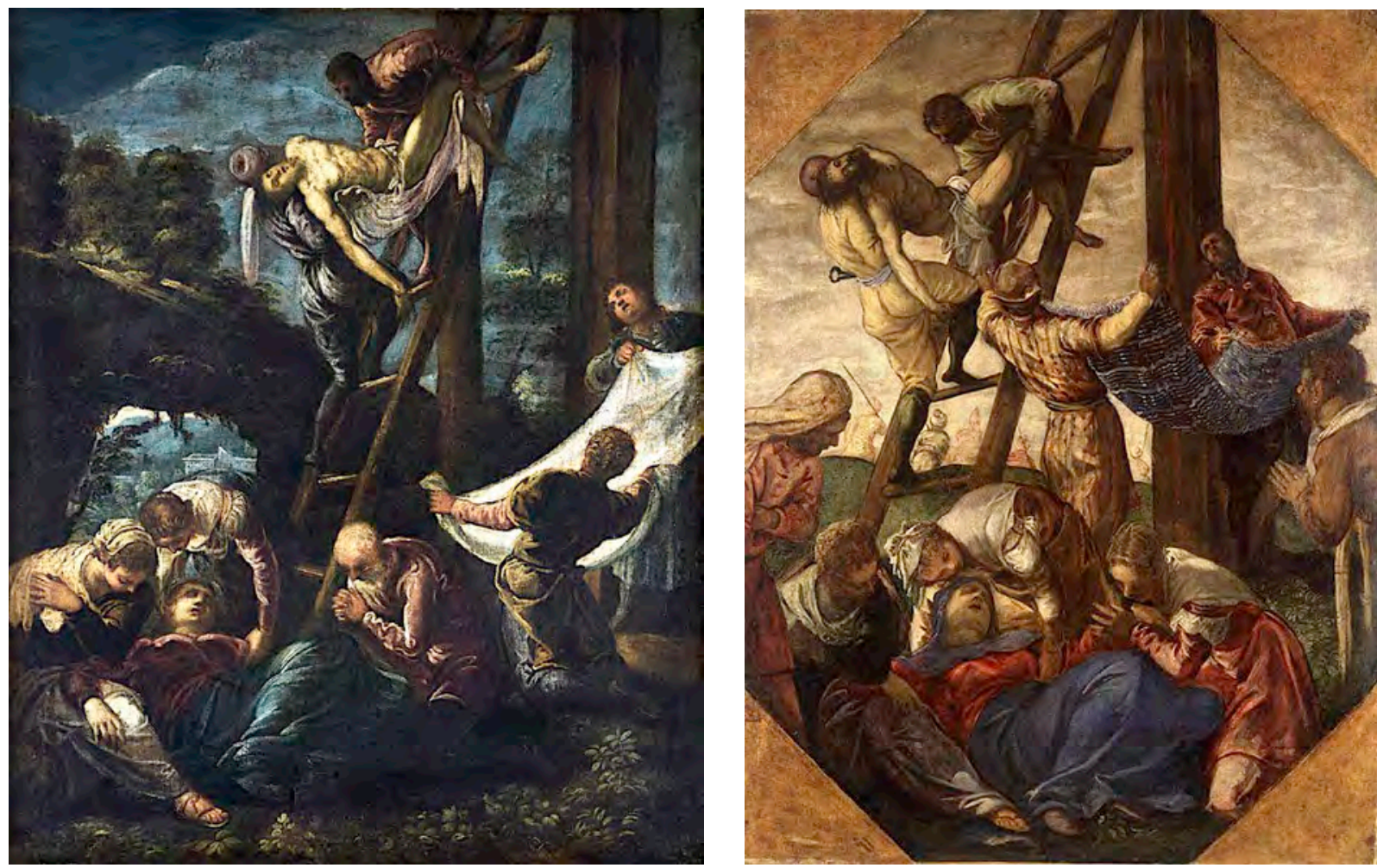

Fig. 43. a, b. Jacopo Tintoretto, Davallament de Crist de la creu del Musée des Beaux-Arts de Caen i Davallament del Musée des BeauxArts d'Estrasburg, v. 1575-1580.

86 Es considera procedent de la demolida Santa Maria dell'Umiltà, primera església jesuítica a Venècia; vegeu Peter HUMFREY, «Tintoretto e la pala d'altare», R. ECHOLS i F. ILCHMAN (eds.), Tintoretto..., p. 122-143, esp. p. 124-125. apreciar que el pintor hi ha introduït canvis notables, fins al punt que la temàtica, sovint reconeguda com a Deposizione della croce, ja no es correspon de manera prou fidel amb I'antic episodi en què Crist és baixat de la creu (fig. 44). ${ }^{86}$ En aquest cas, la tela va ser retallada a la part alta i hem perdut un fragment important de la pintura, que tindria un format vertical, tal com es pot apreciar en el gravat de Sadeler Aegidius II (15681629) a partir de Jacopo Robusti, el Tintoretto (1518-1594), de $212 \times$ $390 \mathrm{~mm}$, que ens descobreix la part desapareguda, on s'inscriuen dues escales i la creu sobre un sol Iluminós que recorda aquell al qual se sobreposa Crist al Calvari de I'Albergo. Tal com advertia, ja estigui la imatge completa o incompleta, no em sembla que permeti parlar de Deposizione. Tintoretto vol assenyalar el lloc del Calvari i recupera una solució coneguda per representar la Pietat de Maria. Es podria pensar que coneix el Davallament de la creu del Museo del Prado de Rogier van der Weyden, que ja enclou la Mare de Déu desmaiada, fent un ben conegut joc amb el cos de Crist; ara bé, el plantejament de Robusti va més enllà quan margina de I'acció 
el paper de les escales i la creu, testimonis d'un moment precedent, i fa èmfasi en la posició del cos de Crist, mort damunt de la falda de Maria. Un dels homes que han contribuït a fer possible I'operació, i en aquest sentit cal recordar Josep d'Arimatea i Nicodem, encara sosté Crist per les espatlles. La Magdalena obre els braços i s'exclama, i una segona Maria s'ocupa de la mare que veu morir el fill. El grup s'ha vist abreujat encara més del normal, fet que no pot sorprendre si tenim en compte que la Pietat estricta, ja fos gòtica o renaixentista, havia perdut des de feia temps quasi totes les figures que omplien els Davallaments i els Planys sobre el cos de Crist mort. ${ }^{87}$ La solitud de Maria amb Jesús a la falda no és l'ideal que es persegueix. Això no obstant, el corrent degota en aquesta direcció.

Al taller de Tintoretto es fa correspondre una segona versió, conservada al Kunsthistorisches Museum de Viena, de la temàtica plantejada en I'obra que pertany a I'Accademia veneciana. Aquesta pintura, també vista com a Deposizione, es valora com a producció anterior (v. 1547-1549) que, en tot cas, prepararia aquella que acabo de comentar. La idea és molt similar i tampoc no disposem de la part superior del quadre, que s'obre clarament al paisatge i caracteritza les figures dels criptocristians tocades per la mateixa lluminositat que sacralitza la resta dels personatges. Sembla evident que ni en el cas anterior ni en aquest és possible parlar d'un descens de la creu en sentit estricte. Tot i així, probablement tampoc no seria just del tot assenyalar l'episodi tout court com a Pietat, ja que som davant d'una visió de compromís, a mig camí entre dues seqüències de la història, que la iconografia fixarà com a models tancats que es repeteixen sovint. Tanmateix, Tintoretto demostra saber molt bé que aquests mòduls
${ }^{87}$ Aquesta opció no és exclusiva, ja que es difonen en parallel versions de la Pietat de la Mare, envoltada dels fidels que encara es planyen. 
88 De I'entorn de Tintoretto es poden esmentar altres obres semblants, com ara la del Museo Soumaya de Mèxic, situada versel $1555-1559(51 \times 75 \mathrm{~cm})$. És interessant advertir, en aquest cas, la desaparició de la creu i les escales i la voluntat de centrar l'atenció en I'encreuament de les figures de Crist i Maria sense negligir l'embolcall corresponent que ofereixen els restants seguidors de Crist. no són determinants per a la riquesa narrativa dels fets, que permeten ombrejats de tota mena i natura. ${ }^{88}$

El Tintoretto retorna encara sobre aquest episodi en la seva Pietat de la lluneta del cortile de les Procuratie di Supra, avui a la Pinacoteca Brera de Milà. Se'n va documentar un pagament el 1563 i també se sap que I'obra, descrita com a Christo morto colle marie, fou restaurada pel pintor el 1590 (fig. 45a). El canvi fonamental per deixar l'escena de compromís, en què la narració genera el sentit, i passar a determinar una Pietat és el fet que Maria ha tornat en si i, amb les mans en oració, es mira plorosa el fill que té a la falda. El cos de Crist està construït amb fermesa i té un pes i una consistència importants, però es desenvolupa amb elegància i amb un Iligam estilístic precís amb totes les figures que I'envolten. Una d'elles és Maria Magdalena, que repeteix el gest d'obrir els braços que feia sant Joan al Plany pintat per Giotto a I'Arena. Ella mostra els ulls embotornats pel plor i un curiós disseny d'aurèola que actua com a plat volador rere el cap (fig. 45b). El segon acompanyant de la Mare i el Fill és una figura jove i barbada que seria possible identificar amb sant Joan, sempre que no hi vulguin trobar parentiu amb el sant Joan del Calvari de la Sala dell'Albergo. Cal constatar també que les típiques aures lluminoses de Tintoretto tenen aquí una consistència més gran que insinua aurèoles ben formades.

Si cerquem una Maria Magdalena de Paolo Caliari, més conegut com a Paolo il Veronese (Verona, 1528 - Venècia, 1588), la descobrirem en I'escenari de la seva conversió, vers el 1546-1548, en un oli sobre tela de $117,5 \times 163,5 \mathrm{~cm}$ que pertany a la National Gallery de Londres. Quelcom d'aquesta Magdalena impregna la figura de Tintoretto a la lluneta de la Brera, una imatge esplèndida, del més destacat de la composició, suau, alhora que intensa i emotiva. També es vincula a II Veronese el Noli me tangere del Musée de Grenoble, del tercer quart del segle XVI $(67 \times 95 \mathrm{~cm})$, però en aquest cas la situació podria ser la inversa i fer pensar en l'interès que despertaria Tintoretto en el de Verona o en la proximitat entre ambdós quan es tracta de pintar temes amb contingut mitològic o aferrats a I'Antic Testament. No debades, les Maries i els àngels del segon terme tenen un aire evanescent que assoleix més fondària plàstica en I'obra de Tintoretto.

Quan parlem del discurs de la Pietat, no podem prescindir de la darrera de les obres que es vinculen a Tiziano, realitzada vers el 1573-1576 i destinada a la tomba de l'artista, i que, amb intervenció de Jacopo Palma el Jove, pertany ara a les Gallerie dell'Accademia de Venècia (fig. 46). Sigui quina hagi de ser la valoració d'aquesta obra mestra i de la seva autoria, I'esperit de Tintoretto la tenyeix en diferents dimensions pictòriques que garanteixen la prominència conferida al context arquitectònic sense defugir en cap moment 

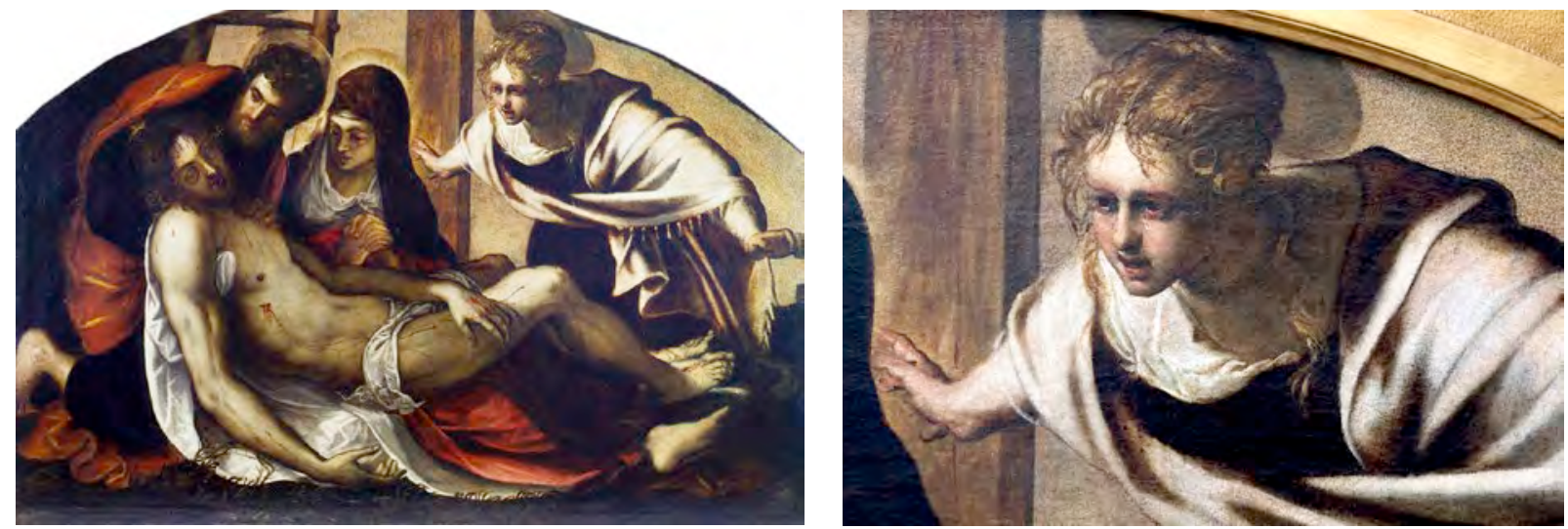

Fig. 45. a, b. Jacopo Tintoretto, Pietat de la lluneta del cortile de les Procuratie di Supra i detall de la Magdalena, Pinacoteca di Brera de Milà.

les al/lusions escultòriques. Un Moisès monumental, aixecat com a estàtua amb les taules de pedra, situa el límit de I'Antiga Llei davant d'una plausible santa Helena-Església portadora d'una gran creu. Ambdós s'emplacen damunt de grans capitells decorats amb enormes caps Ileonins. Entre Moisès i Helena veurem la Mare amb el Fill a la falda, asseguda en una banqueta, una Maria Magdalena que sembla demanar ajut, una noieta amb un recipient i un personatge vell que acaba d'arribar-hi i que, a ma- nera d'eremita penitent que s'aferra a Crist, s'ha volgut identificar amb la imatge de Tiziano mateix. Un angelot volador, portador d'una torxa encesa, completa la visió funerària, amb tons de color tothora excepcionals, i revela un hemicicle absidal amb la conca també pintada on sembla poder intuir-se la figura del pelicà. Altres detalls posen l'accent en la dimensió devota que adquireix el tema dins I'enquadrament simbòlic determinat i també permeten destacar la inscripció al·lusiva als pintors, damunt de la plataforma que descriu un presbiteri factici.

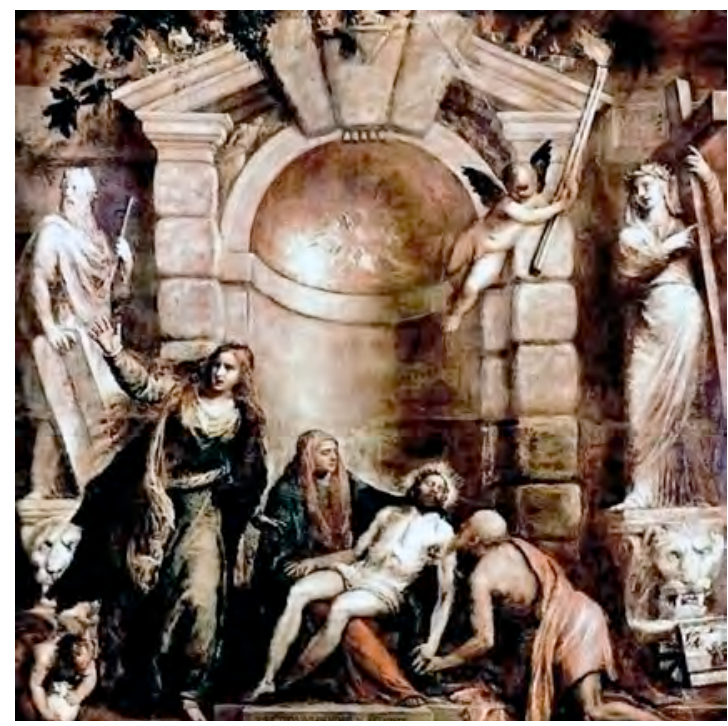

Fig. 46. Tiziano Vecellio amb intervenció de Jacopo Palma el Jove, Pietat, v. 1573-1576, Gallerie dell'Accademia de Venècia. 
89 La resurrecció de Llàtzer, de Tintoretto, oli sobre tela de la Scuola Grande di San Rocco, v. 1579, ofereix referents interessants per a les actituds i el discurs dinàmics que el pintor $\mathrm{i}$ el seu taller apliquen a qualsevol tema. La sortida del sepulcre embarassa I'espai amb una capacitat per esdevenir centre lateralitzat de tot I'escenari, cosa que actualitza i fa dels personatges veritables contemporanis del pintor.
El suposat Davallament del taller de Tintoretto del Musée des BeauxArts d'Estrasburg ens retornaria ja vers el 1578-1580 a les fórmules que s'exportaven als olis de l'Accademia i de Viena, però en aquesta ocasió la proximitat de Tintoretto al Veronès és molt menor i es descriu prou bé el nexe amb la pintura conservada al Museo Soumaya de Mèxic. De nou s'obvien la creu i les escales per destacar la relació que configura una imatge preparatòria de la Pietat en acostar i jeure el Fill a la falda de la Mare. La «narrativitat» terrena s'imposa com a versificació del dolor dinàmic que tensa cadascuna de les figures i que solament alliberen els angelots que volen a la zona superior dreta i esquerra. Tot es mou i, per tant, és difícil veure en aquestes imatges un patró de culte, una icona que fixa el seu valor simbòlic per damunt del moviment convuls que talla l'ancoratge del tema com a episodi prefixat. Els ulls oberts de Maria fan preveure la Pietat, però la Pietat és encara una potencialitat retinguda en la imatge. El mateix podem afirmar del Davallament, que, com a tema, ja forma part del passat. ${ }^{89}$

El Raffaello que podem apreciar a la Pala Baglioni de la Galleria Borghese, a Roma, ens retorna al capteniment dels temes que han deixat de ser allò que havien estat. Ara som, més que no pas al Davallament de la creu, davant del trasllat del cos de Crist a braços. Les Maries, que eixamplen el recompte més que de costum, i altres personatges que són més dels habituals també en el sector masculí, no participen realment del trasllat, però plàsticament sí que ho faran, ja que Rafael cerca lligams entre cada figura, creua alguns dels peus dels protagonistes i fa difícil verificar l'entitat autònoma de cada personatge. En aquest instant de la narració vol explorar un desmai allargassat de la Mare i un nexe entre Crist i Maria Magdalena, que impacta damunt del rostre del Crist mort, inert, amb la suggeridora capacitat de Rafael per crear representacions d'una bellesa pertorbadora. Al fons, les tres creus i un parell de personatges són l'únic record d'allò que entenem per Davallament de la creu. L'obra de Rafael és del 1507 i no menystinc el fet que un jove Tiziano, ja cap al 1520, també s'ocuparà del tema amb un nou carregament i trasllat del cos de Crist previ a l'Enterrament en una pintura que, en aquest cas, pertany al Musée du Louvre i que és molt més estricta des del punt de vista dels actors que hi participen. Maria s'ha recuperat del desmai i la Magdalena s'hi abraça, mentre que J osep d'Arimatea, Nicodem i sant Joan s'ocupen del trasllat. No cal recórrer a I'espai del Calvari. Aquests precedents, més que vincular-se a les solucions anteriors del taller de Tintoretto, ens acosten a I'oli de collecció privada que s'ha datat vers el 1557-1559 (104 × $135 \mathrm{~cm})$ (fig. 47) i, seguint els esquemes propis de l'artista venecià, ens deturen encara al peu de la creu en la imatge del transport del cos una vegada s'ha culminat el 
descens. Tintoretto sembla revisar allò que s'havia fet abans per insistir amb una contundència admirable en el relat que uneix un present a un passat. La figura que encara no ha acabat de baixar de la creu apuntala el Crist per la dreta, mentre sosté el llençol que un segon personatge agafa per la banda oposada, que correspon a les cames de Jesús. La Magdalena torna a ser protagonista, i les Maries, figures ennegrides a I'entorn d'una Mare desmaiada i realçada pel to vermellós de la túnica. El conjunt, que podria haver estat retallat, matisa el fons esmorteït amb núvols de puntes blanquinoses molt properes. Hi notem solament dos aspectes rellevants, encara que n'hi ha més: un correspondria a la disposició del cos de Crist en I'espai, que toca el terra amb els dits plegats de la mà esquerra, i I'altre queda contingut en la figura que fa una passa embolcallada pel mantell i deixa visible el peu nu, que la projecta endavant, i poca cosa més que un petit fragment

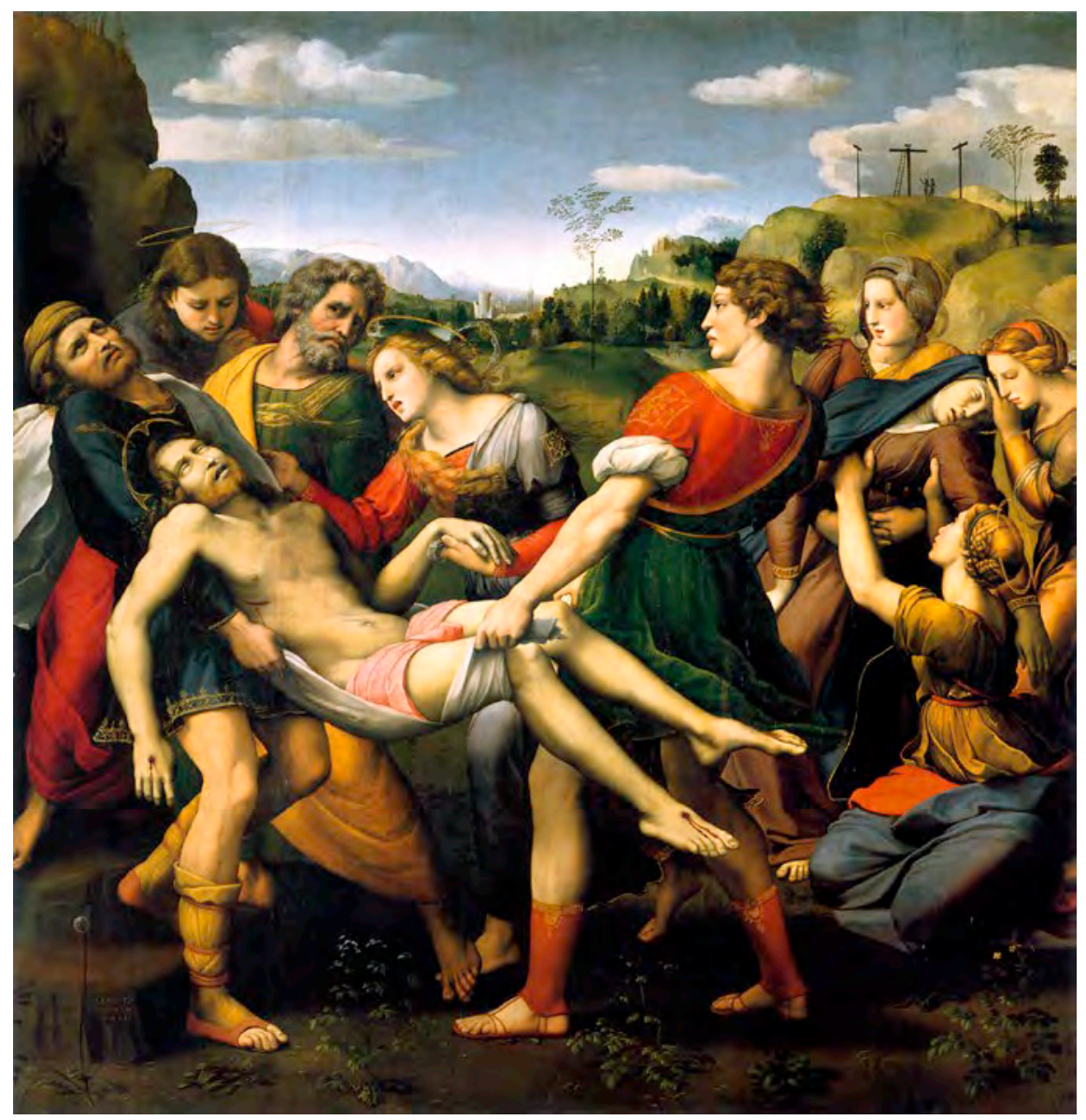

Fig. 47. Jacopo Tintoretto, Trasllat del cos de Crist, collecció privada. 
$90 \mathrm{~S}$ 'han fet altres lectures de la iconografia d'aquestes pintures, però soc partidària de mantenir la lectura tradicional; en tot cas, aquesta problemàtica, que exigiria una atenció específica, no és el tema central del meu article. del rostre. El discurs del trasllat serà endreçat també per Jacopo Palma el Jove en un dibuix que és reconegut ja com a Trasporto di Cristo al sepolcro vers el període 1607-1620.

Tanmateix, per entendre l'impacte $d$ 'aquesta mena de seqüències en el catàleg de Tintoretto i en les obres dels seus seguidors, és del tot impossible menystenir les escenes dedicades a sant Marc a la Scuola Grande di San Marco. El Trafugamento del corpo di san Marco, situat vers el 15621566, és un gran oli damunt de tela $(398 \times 315 \mathrm{~cm})$ que gestionen les Gallerie dell'Accademia, mentre que el Ritrovamento del corpo di san Marco, 1562-1566, oli sobre tela $(396 \times 400 \mathrm{~cm})$, pertany a la Pinacoteca di Brera de Milà (figs. 1, 42a i 42b). ${ }^{90}$ No introduiré ara totes les consideracions que caldrien davant $d^{\prime}$ aquestes pintures, que es troben entre les que més fama han aportat al pintor. L'enginy espacial i l'acurada posada en escena, malgrat els retalls prou demostrats en algun dels episodis, perviuen intactes en aquests fragments de pintura que revelen tot el poder dramàtic de l'artista i la seva contundència expressiva. El personatge que transporta les cames de sant Marc al Trafugamento trepitja la línia que delimita el marc. No es pot dir que l'efecte, com a concepte o proposta en sec, sigui nou, però sí que ho són la solució i el virtuós impacte sobre el terra, on es dibuixa un cercle de llum al voltant de l'extremitat del personatge implicat. I així molts altres detalls i elements que, com ara les ombres esperitades que abandonen l'escenari o la figura que vol retenir el camell, ens expliquen a la perfecció algunes de les coordenades en què Tintoretto es mou.

Ara bé, si hem de continuar resseguint el discurs de la Passió, és essencial aturar-se en I'anomenat Enterrament del Crist d'Edimburg, a la National Gallery of Scotland, 1563-1565 (oli damunt tela, $164 \times 124 \mathrm{~cm}$ ) (fig. 48a). Alguns segueixen veient el tema com a Davallament de la creu o també com a Trasllat de Crist mort, però el fet és que en la pintura s'hi troben implícites o reagrupades, i replantejades, les imatges del Calvari, el Davallament, el Plany, la Pietat i el Desmai de la Mare de Déu. El conjunt, que pertanyia a I'església de San Francesco della Vigna, ha estat retallat a la part superior, amb la corresponent pèrdua d'un àngel que volava al centre del cel de la imatge, de manera que a l'esquerra es deixava visible el Calvari, on hi havia les tres creus, en dues de les quals romanen més o menys abandonats els dos Iladres. L'àngel era portador de la corona d'espines i el Gòlgota evidenciava I'existència d'una creu central buida. Tots aquests detalls, invisibles ara en la pintura, es poden recuperar gràcies als gravats de Jacob Matham (v. 1571-1631) a finals del XVI i, ja d'inicis del XVII, de Lukas Kilian (1579-1637) (fig. 48b), que inverteixen la composició i que, com en altres casos, ens donen un cop de 
mà, per bé que la transcripció no es pugui considerar ni pressuposar del tot exacta i admeti algunes variants si es comparen les dues interpretacions.

Tintoretto trena el desmai de la Mare de Déu en companyia de les Maries, segons s'ha vist en altres pintures comentades. El més estrany ara és el seu emplaçament en el primer terme, que resol de manera original i sense renunciar a les formes consistents dels cossos d'aquestes dones. No pretén ser discret o fer-les passar desapercebudes. Per damunt dels seus caps hi ha l'espai que creix en vertical i que permet asseure la imatge de Crist sobre l'espatlla i els braços $d^{\prime}$ 'aquells que el transporten, tot entronitzant la figura i admetent un posat per a la figura inanimada que no havíem vist abans clarament formulat. S'hi acostarien la Pietat de Tiziano, en la línia de la Pietat vaticana de Miquel Àngel, o la Pietat del mateix Tintoretto a la Pinacoteca di Brera, però el tema és tot un altre. No és la mare la que ofereix ara la falda acollidora al fill mort, i la idea d'un cos transportat fent cadireta s'imposa per tal de fixar una imatge de Crist que esperen dues dones, o Maries, que il|luminen el camí amb ciris encesos en la zona que raneja a la tomba. Observem la porta oberta en la roca, més visible al gravat que a la pintura, com a espai funerari habitual. Creada per al conjunt franciscà observant de Sant'Andrea della Vigna (construït
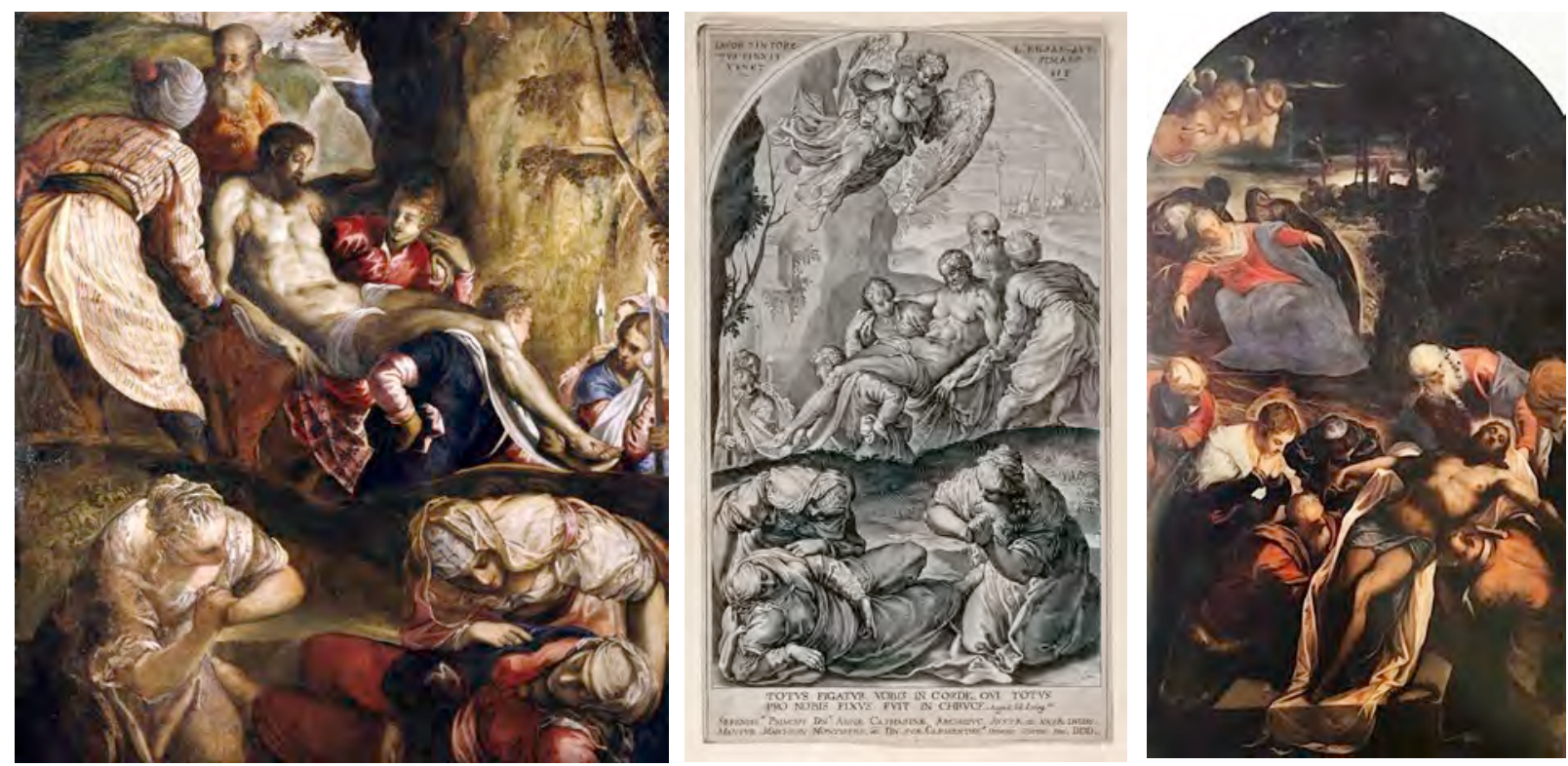

Fig. 48. a, b, c. Jacopo Tintoretto, Enterrament de Crist d'Edimburg, v. 1563-1565, National Gallery of Scotland; Jacob Matham, gravat de l'Enterrament de Crist de Tintoretto, finals del segle Xvi; La deposizione nel sepolcro, de l'església del monestir de San Giorgio Maggiore, Venècia. 
${ }^{91}$ Fernando CHECA, Tizianoy la monarquía hispánica. Usos y funciones de la pintura veneciana en España. Siglos XVI y XVII, Madrid, Nerea, 1995. el 1437) a Venècia, la pintura va abandonar el 1642 el marc original. Ridolfi adverteix que el conjunt va ser mutilat per una mà sacrílega, mentre que Boschini diu que el quadre hauria estat robat.

L'Enterrament de Crist de Tiziano, obra encarregada pel rei Felip II (1556-1598) el juliol de 1559 per a l'església del monestir d’El Escorial, entra de ple dins del discurs que ens interessa per entendre Tintoretto i, a la par, el seu constant diàleg amb el més gran rival, que marcava apreciats patrons pictòrics a l'època, dins i fora del context venecià, alhora que mantenia Iligams importants amb el context hispànic. ${ }^{91}$ El Crist de Tiziano no arriba a tocar terra amb la mà i sembla que pondera el xoc que Tintoretto havia imposat en la versió, ja comentada, d'aquells mateixos anys (fig. 47). Els colors blau i grana de la pintura de Tiziano sobresurten brillantment sense subestimar el paper d'altres pigments que enriqueixen la blancor somorta del cos de Crist, que contrasta amb el blanc lluent d'algunes teles però s'allunya de la més apaivagada claror d'un sepulcre decorat amb relleus narratius.

La remor d'aquestes obres s'aprecia en la pintura retallada que Aegidius Sadeler crea a partir d'un treball de Federico Barocci (Urbino, 1535-1612). L'esment ens ajuda a veure com el trasllat és trasllat quan vol ser-ho, i el pintor obliterà els encaixos constructors d'ambigüitats tipològiques que, en bones mans, esdevenen encertades, suggeridores i imponents. Tintoretto no només aconsegueix interessar gràcies a una transformació que convida a la meditació sobre la Passió de Crist de manera molt eficaç; en realitat, el seu art prospera en ambdós sentits perquè posa cada element al servei d'una nova manera de pintar. Destaca els aspectes físics de la mort, la presència de la sang, però no és aquesta presència per si sola la que té interès, sinó sobretot la manera d'integrar-la en la pintura.

El conjunt d'Edimburg té el seu paral|lel en el conjunt més tardà de $L a$ deposizione nel sepolcro, de I'església del monestir de San Giorgio Maggiore, a Venècia (fig. 48c). La composició s'inverteix i el desmai recula al segon terme, fent clara memòria del Calvari, que s'albira al fons, mentre que I'Enterrament té $l l o c$ al primer terme amb una perspectiva aèria sobre el cos de Crist que sembla voler reviure el clavament a la creu, en la sang que no deixa de rajar i que taca el blanc amb persistència tossuda. El Iligam amb l'altar proper resulta evident i uneix el tema al misteri eucarístic. Des d'una altra perspectiva, la disposició de Crist sembla rememorar les imatges dedicades al retrobament del cos de sant Marc i I'escorç que abreuja la distància entre els peus i el cap, com ja havia plantejat Mantegna al famosíssim Crist mort vers el 1474-1480, avui a la Pinacoteca di Brera de Milà. 
El recorregut per aquesta Passió segons Tintoretto es podria tancar amb el Cristo morto sorretto da un angelo de la Galleria Nazionale di Arte Antica de Trieste. Les ferides són, en aquest cas, discretes i la sang ha perdut protagonisme (fig. 49). L'àngel guanya entitat corpòria i el seu rostre i I'avantbraç semblen envermellits per I'esforç. Les tintes roses i malves o liles que toquen el blau delimiten les tonalitats humanes de la pell de Crist i imposen la idea del sepulcre sense menystenir el poder de la divinitat que garanteix l'àngel. El Crist es pot apropar al que hem vist en el mateix pintor a Sant'Andrea della Vigna, encara que seria precedit per les solucions d'un Antonello da Messina (v. 1430-1479) o d'un Giovanni Bellini (1433-1516). L'Ecce Homo de Tiziano Vecellio també mereix ser recordat. En aquest cas, és una pintura sobre pedra del Museo del Prado, regalada a Carles $V$, que, alhora que es data el 1447, revela en part el to auster i encisador, bizantí i ennoblit, que sembla interessar a Tintoretto. D’ulls entreoberts, el Crist de Tiziano no abona el tancament d'ulls que advertim en l'obra d'aquest darrer i en la dels altres pintors esmentats. El Crist de Tiziano s'aparella amb una Mater Dolorosa que tindria el seu precedent en una corpòria i impactant Dolorosa anterior que remunta al 1516-1518. El Cristo morto sorretto da un angelo de Trieste és avalat

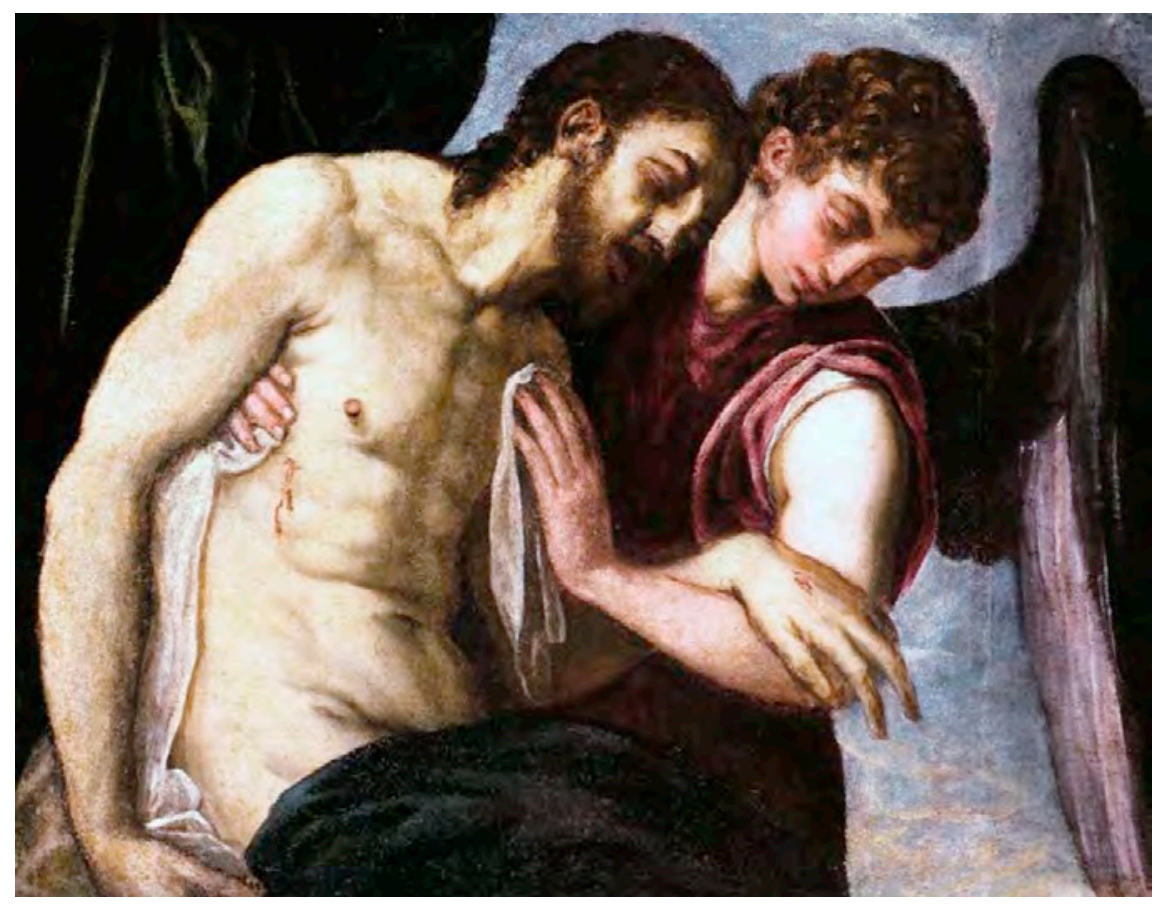

Fig. 49. Tintoretto, Cristo morto sorretto da un angelo, Galleria Nazionale di Arte Antica, Trieste. 
92 Potser Sartre exagera en aquest punt, tal com adverteix Philippe LANÇON, «Tintoret, la sensation de Venise» [en línia], Libération, 11 de març de 2018, https://next.liberation.fr/arts/ 2018/03/11/tintoret-la-sensa tion-de-venise_1635353, fent ressenya de l'exposició oberta al Musée du Luxembourg, «Tintoret, naissance d'un génie». Ara bé, potser hem d'acceptar que exagerar una mica no és mentir del tot.

93 Continua: «Non pas ciel d'angoisse, ni ciel angoissé; c'est une angoisse faite chose, une angoisse qui a tourné en déchirure jaune du ciel et qui, du coup, est submergée, empâtée par les qualités propres des choses»; Jean-Paul SARTRE, "Qu'est-ce que la littérature?», Situations, II, París, Gallimard, 1948, p. 14. "Le Séquéstre de Venise» serà publicat a Les Temps Modernes el 1957 i a Situations, IV.

94 En concret, Tintoretto, de Didier Baussy (1984), número 10 dins d'una sèrie més àmplia: Portrait of an artist. per una tradició que té arrels fondes i que sintetitza un discurs que clourien I'alliberador Davallament de Crist als inferns i la seva Resurrecció.

\section{La llibertat del segrestat de Venècia}

Es diu que Tintoretto, el robust i de vegades tempestuós artista que ens ha explicat la Passió, aplegava tres pinzells ben diferents: el primer era el pinzell d'or, el segon era el de plata i el tercer era el de ferro. A partir $d^{\prime}$ aquesta imatge s'intenta resumir el valor de la seva pintura, i és evident que les tres modulacions es fan visibles en la confluència amb els escenaris que hem visitat. Segons el que faci al cas, s'haurà d'interpretar el sentit dels tres presents pictòrics que falquen produccions religioses de caire cristià o mitològic i que poden fer pensar en tonalitats singulars per a les unes i les altres. Ja siguin fixos o variables, els tres pinzells s'integren vinculats a les passions i, ben metafòricament, els podem entendre vinculats al luxe bizantí dels pigments més amistosos, a la lluentor de les llums i els blancs que els acompanyen o a la negror que travessa les superfícies i genera figures que tenen la fortalesa del ferro, sí, i alhora les vibracions de I’or i de la plata.

Les dues darreres obres de Tintoretto se situen el 1594, any fixat per a la seva mort, encara que en algun cas es parli d'una desaparició durant la pesta de 1596. El 1594 va crear, per a I'església de San Giorgio Maggiore, La caiguda del mannà i El Sant Sopar. Dels sis autoretrats que se li atribueixen, el darrer es conserva al Musée du Louvre i, datat I'any 1587, ens el pot recordar en aquesta etapa final del seu trajecte (fig. 50). Jean-Paul Sartre va interessar-se molt per aquest autoretrat d'un Jacopo Robusti ancià, al qual va rebatejar, una vegada més, qualificant-lo de "séquestré de Venise». El talp venecià, sempre reticent a abandonar la Sereníssima, hauria creat, a parer del filòsof, sèries que no hauria estat disposat a fer per a altres llocs. ${ }^{92}$ Davant per davant de la cinematogràfica Crucifixió de la Scuola Grande di San Rocco, Sartre pensava en un director de cinema i escrivia després que I'esquinçament groc que pinta al cel del Gòlgota no havia estat triat per Tintoretto per representar l'angoixa i encara menys per provocar-la. Segons el filòsof, són l'angoixa i un cel groc pintats al mateix temps: "Cette déchirure jaune du ciel audessus du Golgotha, le Tintoret ne l'a pas choisie pour signifier l'angoisse, ni non plus pour la provoquer; elle est angoisse, et ciel jaune en même temps». ${ }^{93}$

S'ha remarcat que aquesta gran tela mural ha estat font d'inspiració d'una pel-lícula documental, ${ }^{94}$ però el fet és que Tintoretto crea per si mateix un discurs artístic poderós que transcendeix el moviment de la 
càmera. Al Calvari de la Sala dell'Albergo no li cal el moviment recreat pel cinema per configurar una pintura dinàmica. És un espai fix per on les figures poden circular realment, que es revela ple de potencial i obert en la seva armadura complexa dins d'un discurs temporal extens. El camp sembrat per Tintoretto, a San Rocco especialment, es dilata sobre les grans superfícies que, una per una i fent passos en diverses direccions, el pintor destinaria al relat de la Passió de Crist fins a conquerir el to i el sentit visual

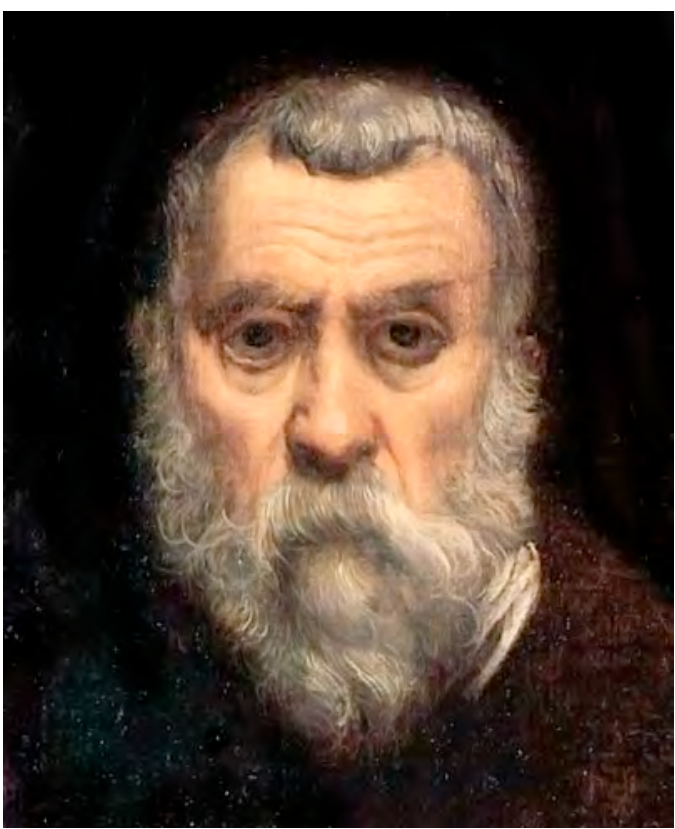

Fig. 50. Tintoretto, Autoretrat, 1587, Musée du Louvre. i narratiu d'allò que qualifiquem d'iconogràfic i que pot ser quelcom més que icònic o teatral en les seves mans.

Segons Sartre, "Avec le Titien, la peinture étouffe sous les fleurs, elle se nie par sa propre perfection». Per a l'escriptor francès, és Tintoretto el primer que desvetlla del son la ciutat dels canals per intranquil.litzar els seus habitants amb una mirada realment innovadora. Quan Sartre, a banda de fer aquestes i altres afirmacions, treu conclusions sociològiques, més o menys arriscades, sobre les voluntats d'aquests pintors i l'esperit que els mou, potser no m'interessa tant com constatar que l'existencialista intueix perfectament una idea que crec fonamental a l'hora d'explicar la Passió segons Tintoretto quan diu clarament que «I'histoire est racontée en entier». ${ }^{95}$ Recordem que Sartre distingeix tot un seguit d'importants «peintres courtisans», al costat dels quals Tintoretto resulta, sempre al seu parer, un pintor d'una altra espècie, treballi per a qui treballi.

Tintoretto ens explica la història sencera. Cada element que entra en el joc altera les constants que el rodegen i fa moure els esdeveniments que es fan visibles vers un nou instant que coneixem i esperem. Per tant, la duració és, en l'obra de Tintoretto, un vector que es troba en les coses, en els homes i en les posicions i que cal intentar apreciar i fer sobresortir en la seva idea narrativa. Uns plantejaments del discurs que trenquen amb els motlles reconeguts o establerts, per més que tinguin antecedents. Subs-
95 Sartre preparava una nova edició per al 1962 a partir d'un seguit de breus anotacions que han estat transcrites a Michel SICARD, «Sartre. Approches du Tintoret» [en línia]: http:// michel-sicard.fr/textes/sartre/ approches-tintoret-2005.pdf. Recollit a Albert GAUVIN, "Sartre, Venise et le Tintoret» [en línia], Philippe Sollers. Sur et autour de Sollers, www.pilefa ce.com/sollers/spip.php?arti cle1809. 
cric aquestes anotacions de Sartre quan s'adona així mateix del paper que tindrà l'espai en relació amb l'escultura i la pintura, ja que és en aquest pla on les coses prenen la seva força, el seu ferro, i on exterioritzen les tonalitats platejades i els ors.

Hem de creure en Miquel Àngel però també en Giotto, és clar, sempre a la base. A partir d'aquí, el joc de la llum i de les ombres crearà en Tintoretto les distàncies, els encobriments, els silencis i les afirmacions que recorren uns espais que han triturat els plens per definir els buits com a transicions imprescindibles on, de vegades, ens trobem i retrobem les figures. No es tracta de ser equidistant entre el dibuix i el color, entre Miquel Àngel i Ticià, sinó de resoldre a través de la llum i de les ombres l'ossada de cada nou experiment. Tintoretto, alhora que inquieta el color com a estructura, pinta amb la línia molts dels seus espectres, assumint el dibuix com a palpitació pictòrica i com a gesticulació excepcional i profundament especulativa (fig. 51). Tot conjugat I'ajuda a organitzar la cerimònia figurativa en què ens vol introduir de ple. La gravetat (pesanteur) que Sartre aprecia en Tintoretto és allò que entén com la recerca d'una realitat espacial absoluta que també ens acosta a la matèria i es desenvolupa en el gest: una veritable passió dels cossos. No hi ha dubte que els escenaris de la mort de Crist convenen a aquesta visió que percep la distància que separa el pintor de la realitat i teoritza sobre la seva capacitat per reconvertir els fets i determinar-los fins on era possible, seguint sempre criteris que no han deixat de ser artístics.

Segons recorda Sicard, per a Sartre "Le Titien s'oppose au Tintoret comme Dieu au Diable, comme Flaubert à Leconte de Lisle, comme Wols à Klee». Ja sabem que Sartre exagera. No podem no saber-ho des del moment en què apreciem el diàleg pictòric que s'entaula entre els dos grans mestres del pinzell, Tiziano i Tintoretto, i que, tal com he assenyalat a l'inici, i tot salvant les grans distàncies, em fan pensar en la gravetat ( $i$ en el principi de realitat) de Cimabue davant la bellesa més aparent i artificiosa que aflora en la brillant paleta de Duccio.

La llibertat del presoner existeix perquè el captiu lluita amb la seva imaginació per aconseguir sortir del sistema de cercles i impediments en què ha quedat atrapat. El pintor venecià en dona un magnífic exemple $i$ captiva en un món singular tots els que s'acosten a la seva pintura sense gaires prejudicis i amb un bagatge pictòric suficient. És capaç de bastir un enginy de figuracions que avalen diferents moments del seu trajecte. He optat per definir-ho saltant d'escenari en escenari per copsar quelcom d'una genuïna «Passió segons Tintoretto». Aquest recorregut condensat en un article, ja massa llarg, obliga a admirar les escenes finals de la vida terrenal de Crist, a les quals el més autèntic Jacopo, el fill del tintorer, és 


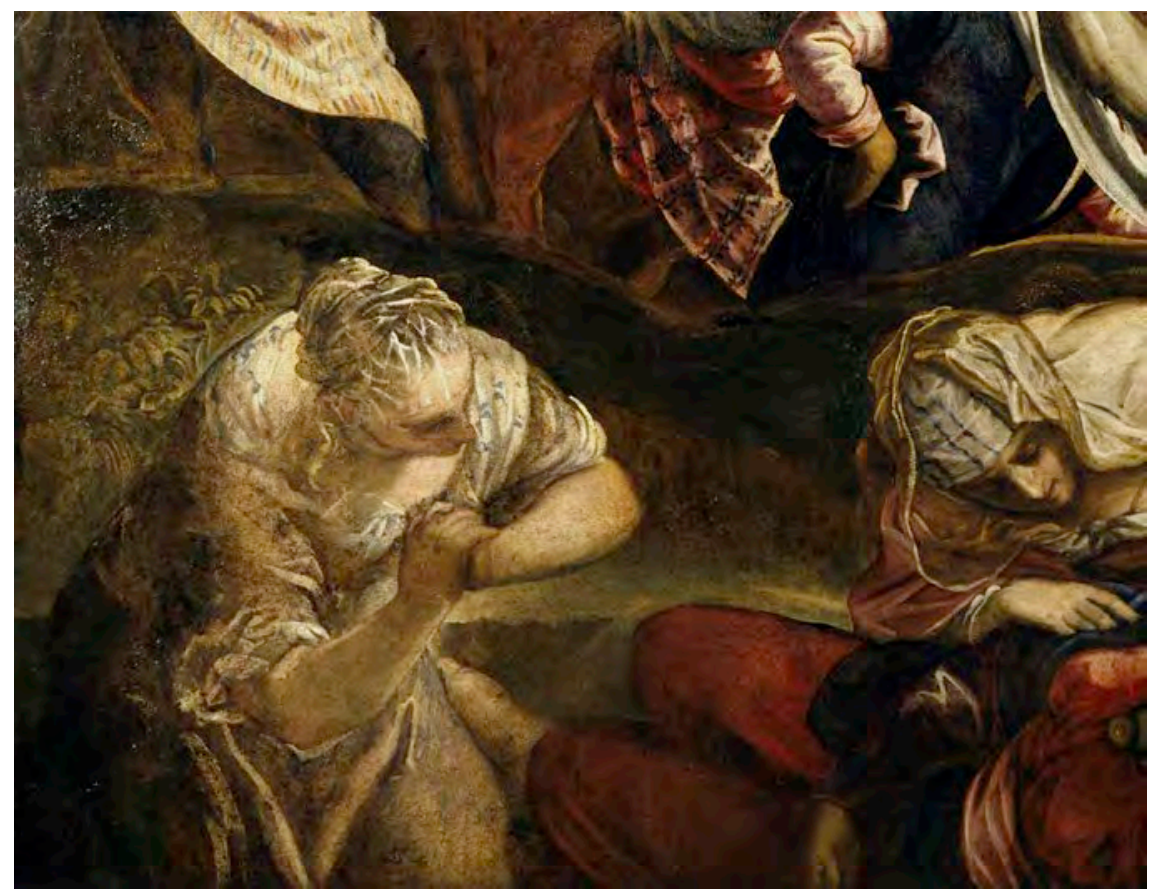

Fig. 51. Jacopo Tintoretto, detall de l'Enterrament de Crist d'Edimburg, v. 1563-1565, National Gallery of Scotland.

capaç de donar noves transparències i una visibilitat rotunda, per declararse veritablement segrestat per la pintura i, al capdavall, ser un captiu voluntari del seu art.

Rosa Alcoy

Universitat de Barcelona

rosaalcoy@ub.edu 
L'article es proposa destacar alguns dels interessos i de les estratègies pictòriques essencials de Tintoretto. El transvasament del seu caràcter impactant a la configuració d'una individualitat pictòrica arriba associat a un llenguatge que, lluny de voler ser arbitrari, desitja sobresortir pels seus valors intrínsecs, alhora que dialoga amb l'art del passat i aprecia la intel.ligència de l'espectador. Si de tant en tant ens desubica, és per obligar-nos a retornar als temes mantenint la tensió precisa. El pintor explica els temes amb una elaboració refinada i en un format visible, un format singular que intenta apropiar-se de l'atenció de qui mira i que no s'agenolla davant de cap discurs oral o escrit. El cicle de la Passió de Crist fa possible explicar pas a pas aquest sentiment del discurs en I'obra de Jacopo Robusti. La seva projecció excepcional a la Scuola Grande di San Rocco avala una trajectòria que no queda reclosa en els seus murs. La institució veneciana és el punt de partida d'un recorregut més ampli que, sense negligir els preliminars temàtics, com ara el Sant Sopar, es planteja valorar també I'aportació d'altres produccions de primer ordre en què la mà de Tintoretto és la més rellevant. En cada cas es considera l'aportació del pintor tenint en compte el seu estil i el catàleg conegut, combinant-ho amb la consideració de produccions d'altres artistes que pertanyen a la seva època o que ajuden a explicar-la en alguna mesura.

Paraules clau: Tintoretto, Jacopo Robusti, Venècia, pintura, segle XVI, Passió de Crist, iconografia

\section{The Passion according to Tintoretto. From the Judgment to the Descent}

The article would like to highlight some of Tintoretto's essential pictorial interests and strategies. The transfer of its striking character to the configuration of a pictorial individuality is associated with a language that, far from wanting to be arbitrary, wants to excel by its intrinsic values while dialoguing with the art of the past and appreciating the intelligence of the viewer. If it occasionally dislodges us, it is to force us to return to the issues while maintaining the precise tension. The painter explains the subjects with refined elaboration and in a visible format: a singular format which wants to appropriate the attention of the one and who looks that does not kneel before any oral or written speech. The cycle of the Passion of Christ makes it possible to gradually explain this sense of narration in the work of Jacopo Robusti. Its exceptional projection at the Scuola Grande in San Rocco guarantees a trajectory that is not closed in its walls. The Venetian institution is the starting point for a broader journey that, without neglecting thematic preliminaries, such as the Holy Supper, also considers the contribution of other first order productions in which Tintoretto's hand is the most relevant. In each case the contribution of the painter is valued taking into account his style and the known catalogue and in combination with the consideration of productions of other artists who belong to his time or that help to explain it to some degree.

Keywords: Tintoretto,JacopoRobusti, Venice, Painting, 16th century, Passion of Christ, iconography 
Aquest article ha estat publicat originalment a Matèria. Revista internacional d'Art (ISSN en línia: 2385-3387)

Este artículo ha sido publicado originalmente en Matèria. Revista internacional d'Art (ISSN en línea: 2385-3387)

This article was originally published in Matèria. Revista internacional d'Art (Online IS S N : 2385-3387)

\section{MATÈRIA}

Revista internacional d'Art

Els autors conserven els drets d'autoria i atorguen a la revista el dret de primera publicació de l'obra.

Els textos es difondran amb la llicència de Reconeixement-NoComercialSenseObraDerivada de Creative Commons, la qual permet compartir I'obra amb tercers, sempre que en reconeguin I'autoria, la publicació inicial en aquesta revista i les condicions de la llicència: https://creativecommons. org/licenses/by-nc-nd/4.0/deed.ca

Los autores conservan los derechos de autoría y otorgan a la revista el derecho de primera publicación de la obra.

Los textos se difundirán con la licencia de Atribución-NoComercial-SinDerivadas de Creative Commons que permite compartir la obra con terceros, siempre que éstos reconozcan su autoría, su publicación inicial en esta revista y las condiciones de la licencia: https://creativecommons.org/licenses/ by-nc-nd/4.0/deed.es

The authors retain copyright and grant the journal the right of first publication.

The texts will be published under a Creative Commons Attribution-NonCommercial-NoDerivatives License that allows others to share the work, provided they include an acknowledgement of the work's authorship, its initial publication in this journal and the terms of the license: https://creativecommons.org/licenses/by-nc-nd/4.0/deed.en

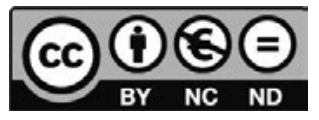

